\title{
SEEKING EXPERTS: AdVISORY COMMITTEES AND THE POLITICS OF BUREAUCRATIC EXPERTISE
}

\author{
KATHLEEN M. DOHERTY \\ NEW YORK, NY \\ BACHELOR OF ARTS, WESLEYAN UNIVERSITY, 2002 \\ MASTER OF ARTS, UNIVERSITY OF VIRGINIA, 2008
}

A DISSERTATION PRESENTED TO THE GRADUATE FACULTY OF THE UNIVERSITY OF VIRGINIA IN CANDIDACY FOR THE DEGREE OF DOCTOR OF PHILOSOPHY

DEPARTMENT OF POLITICS

UNIVERSITY OF VIRGINIA

August 10, 2013 


\section{TABLE OF CONTENTS}

\section{ACKNOWLEDGEMENTS}

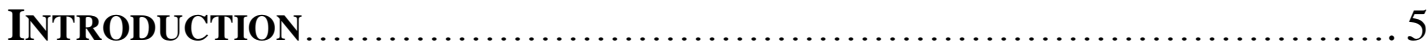

I. Generating Expertise of EXerting Political CONTROL: The Use OF EXPERT AdVISORY COMMITTEES IN BuREAUCRATIC POLICYMAKING ................. 13

II. LAYERING EXPERTS: ADVISORY COMMITTEES, INFORMATION, AND

POLICYMAKING...................................................... 71

III. ADVISORY COMMITTEES AND THE DEVELOPMENT OF EXPERTISE IN THE

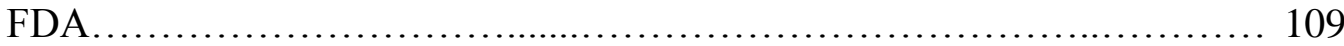

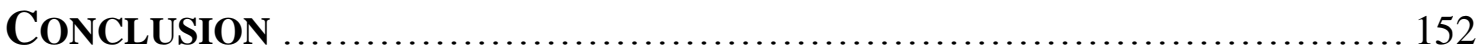




\section{ACKNOWLEDGEMENTS}

I came to this project after some false starts and delays. The support of my advisers has been crucial in bringing it together. So, I must first thank my committee: Jeff Jenkins, Craig Volden, Eric Patashnik, Sid Milkis and Sandy Gordon. Eric encouraged me to come to UVA and has remained supportive throughout the course of my graduate degree. Sid taught me early on the importance of thinking about history even when studying the present. Craig came to UVA towards the end of my time there, but had an important impact on my dissertation. He helped me understand how to frame my arguments and think about where they fit in the literature. I will always appreciate his ability to deliver tough criticism in manner that only encourages you to take another crack at it. Sandy has generously shared his time and knowledge about bureaucratic politics, despite no institutional obligation to do so. He pushed me to think more carefully about the strategic behavior of actors and his guidance vastly improved the project. Finally, there would have been no dissertation without my adviser Jeff. He helped me find this project as well as a research path. He was patient and encouraging in the conceptualization of the project, helped me clarify my ideas, and read my attempts to translate these ideas into coherent papers countless times. His guidance will affect my research long into the future.

The University of Virginia was a supportive environment in which to write a dissertation, and I benefited from the warm friendship and intellectual engagement of Emily Charnock, Justin Peck, Kate Sanger, Greta Snyder, and Brandon Yoder. The university also provided important financial support that gave me time to pursue my research. I received the University of Virginia President's Fellowship (2006-2010) and the Bankard Fund for Political Economy's dissertation year fellowship (2012-2013) as well as additional financial support from the Department of Politics.

In the time that I have spent at New York University, I profited from discussions with a number of individuals. First, Patrick Egan and Jonathan Nagler gave me the opportunity to take their quantitative methods classes in 2010-2011. These classes provided me with methodological skills that were vital for carrying out this project. I must also thank Thomas Brambor who in his time there was a cheerful, office mate, tireless statistics tutor, and a good friend.

The first two chapters also benefited from the discussion at the Midwest Political Science Association Conference in 2012 and 2013 and the NYU Junior Political Science Reading Group in 2011. I received helpful comments from a number of people, but I am especially grateful to Dave Lewis for providing extensive feedback on both papers. His comments as well as his research had an important impact on my work.

For the historical research, I relied on the support of people at several research libraries and archives. I must thank the librarians at the National Library of Medicine (NLM), the Library of Congress, the Francis Countway Library of Medicine at the Harvard Medical School, and the Alan Mason Chesney Medical Archives at Johns Hopkins University Medical School. Several individuals were very helpful, including Marjorie Kehoe at Johns Hopkins, Jessica Murphy at Harvard, and John Rees at the NLM. I am also grateful to John Swann, the Food and Drug Administration Historian, for providing me with some documents and generally guiding me as I tried to learn about pharmaceutical drug regulation in the 1960s and 1970s. Numerous other 
bureaucrats at the FDA, the Environmental Protection Agency, and Office of Personnel Management assisted me as I gathered data about advisory committees, including Eulus Moore, Martha Berger, Pat Childers, Bryan Ambrose, and Bruce Troutman among others.

Finally and most importantly, this project could not have been possible without the love and support of my family. First, I thank my parents, Gail and Brian Doherty, for instilling in me the importance of education, encouraging me to find my own path, and then supporting me on that path. Without them, I could not have made it to this point. I am deeply indebted to my husband, Ryan Pevnick. I found Ryan on the steps of the library on one of my first days of graduate school. In the time since, he has provided intellectual engagement as well as love, laughter, and adventure in Charlottesville, New York and mountains across the country. I want to express how appreciative I am of the many thoughtful discussions he had with me about arguments in the dissertation and the process of writing itself. For him, I am eternally grateful. 


\section{INTRODUCTION}

In contemporary political life, executive agencies are delegated substantial policymaking authority in the name of securing efficiency gains. The debate about delegation has typically revolved around the extent to which elected officials can compel bureaucrats to make to the same policy choices that they would have given time, information, and expertise (McCubbins and Schwartz 1984; McCubbins, Noll and Weingast 1987, 1989; Bawn 1995; Epstein and O'Halloran 1999; Huber and Shipan 2002; Lewis 2003, 2010; Volden 2002). The focus is, as a result, on the efforts of political actors to control bureaucratic agents, despite the formidable informational advantages bureaucrats possess. However, given the breadth and complexity of tasks contemporary executive agencies perform, perhaps an equally important question is how do bureaucrats acquire the information and expertise necessary to formulate policy. This requires a shift in perspective from assuming expertise to one where we consider its origins as well as the ways that institutional design can affect its development (Gailmard and Patty 2007, 2012;

Stephenson 2007, 2011). The ability to control bureaucrats is unimportant if they cannot—within reason—assess the consequences of different policy instruments.

If elected officials are to secure the efficiency gains of delegation, bureaucrats need to possess adequate expertise. Acquiring expertise is particularly difficult in policy areas that require highly trained personnel, especially when those individuals possess desirable private sector employment opportunities or when the policy area in question is subject to rapid technological change. Consider the following examples. How does the Food and Drug Administration (FDA) determine whether to approve a new drug? How do they reconcile conflicting studies regarding the effects of a drug? How does the Environmental Protection Agency (EPA) decide whether to permit the use of hydraulic fracturing to obtain natural gas? 
How do they determine whether the procedure will contaminate groundwater and what levels of contamination are acceptable? How do they assess conflicting, complicated evidence produced by engineers in the agency, academic researchers, and oil and gas firms about the effects of fracking?

Expertise in agencies is not a given. It must be built and maintained, but political principals face numerous challenges in compelling bureaucrats to engage in research effort and acquire expertise. First, agencies have limited resources with which to hire sufficient qualified personnel, and in many technical areas, they face competition for skilled labor from both industry and academia. Second, they must acquire expertise within the constraints of the civil service system and its limits on their ability to hire and fire personnel. Third, agents possess superior information about what they know and their level of effort. It is difficult for a political principal to determine whether agents have engaged in sufficient information-gathering or effort, because the principal cannot easily observe effort or assess the quality of a policy decision, particularly in technical policy areas when the consequences of a policy choice are difficult to discern. There is also a misalignment between the marginal social costs and benefits of information gathering and the bureaucrat's private costs and benefits (Stephenson 2011, 1430; Tullock 1971). Finally, regulation in complex policy areas requires personnel with specialized knowledge and skills. Technological advances, in areas like pharmaceutical drug development and the safety of oil and gas drilling, make the constant updating of skills and knowledge imperative if bureaucrats are to reduce policy uncertainty.

In pursuit of information, expertise, and ultimately competence, political actors may structure institutions in a way that facilitates the development of expertise. Administrative procedure can affect bureaucrat's incentives to acquire information and develop policy expertise 
(Gailmard and Patty 2012). Therefore, political principals can organize bureaucratic decisionmaking in the ways promote research effort. Although much of the scholarly focus has been on how Congress structures administrative procedure, we must also investigate the bureaucratic response to delegation, including how agencies and their leaders organize bureaucratic decision-making (Carpenter 2001, 2010; Huber 2007). There is evidence that these agency leaders can and do adopt strategies within the bureaucracy to shape policy outcomes and further their institutional goals (Carpenter 2001, 2010; Huber 2007; Bertelli and Grose 2009).

Through these papers, I explore strategies that agency leaders adopt to resolve questions of policy uncertainty and improve agency capacity. I do so by examining one institutional tooladvisory committees. Advisory committees provide an institutional forum within the policymaking process for consultation with affected business, private sector interests or external experts. They may only provide information, and their recommendations do not hold the weight of law.

Advisory committees composed of experts from the private sector and research institutions play an active role in agency policymaking. These committees address important public policy issues across the federal bureaucracy. For example, in June 2013, the FDA requested that an advisory committee of medical researchers and professionals assess new evidence regarding the safety of the diabetes drug Avandia (Thomas and Tavernise 2013). The drug was a blockbuster for GlaxoSmithKline until evidence from a Cleveland Clinic cardiologist in 2007 revealed that the drug elevated the risk of heart failure, and the FDA imposed restrictions on its use (Thomas and Tavernise 2013). The committee helped the agency consider the evidence and make a determination about whether the restrictions should be lifted. In 2011, a committee of experts reporting to the Secretary of Energy evaluated the extent to which extracting natural 
gas through hydraulic fracturing negatively affected the environment and a posed a threat to public health through water and air contamination (Soraghan 2011).

My dissertation focuses on the questions: 1) why do agency leaders incorporate advisory committees of private sector experts into the rulemaking process and 2) are they consequential? The dissertation is comprised of three papers. The first paper examines why agencies create advisory committees through an analysis of advisory committee creation and renewal across the federal bureaucracy. The next two papers focus on the use of advisory committees in the FDA. Effectively regulating pharmaceutical drugs requires that the FDA possess highly skilled labor, despite competition from the pharmaceutical firms and academia. In addition, personnel must keep pace with the development of new chemical compounds, advances in knowledge about a wide range of diseases and conditions, and methods for assessing the safety and effectiveness of drugs. The second paper considers whether advisory committee recommendations affect policy outcomes, and what this evidence can tell us about their role in the policy process. The third paper investigates the historical origins of the advisory committee system in FDA. Collectively, the three papers make the case that when agencies face sufficiently high degrees of policy uncertainty, they will turn to advisory committees as one mechanism to improve the agency expertise.

The first paper argues that in technical policy areas, agency secretaries construct expert advisory committees not to control career bureaucrats, but to alter the costs of research effort. These committees can improve information gathering through two mechanisms depending on the point in the policy process they are placed. In the first instance, they can subsidize the private costs of doing additional research, and in the second, they raise the private costs of inadequate research effort. The paper will test this proposition against the alternative that agency secretaries 
establish committees in order to minimize information asymmetries and limit the degree to which subordinate bureaucrats can move policy away from their preferred outcomes.

To evaluate these claims, I have created an original dataset that contains information on the creation, renewal, and termination of every advisory between 2001 and 2011. In the paper, I statistically test whether agencies establish advisory committees to reduce uncertainty about the likely effects of a policy choice, or in order to control ideologically divergent career bureaucrats. The paper shows that agencies primarily create these committees to lower the costs of expertise acquisition among career bureaucrats.

Given that the first paper demonstrates that advisory committees are mainly created in technical agencies, the logical next question is whether these committees affect policy outcomes. The effect of advisory committee recommendations on policy outcomes has important implications for understanding their role in policymaking and how technical agencies cope with policy uncertainty. I argue that agency leaders in the Food and Drug Administration create and maintain technical advisory committees to lower the costs of expertise acquisition for the career bureaucrats. Therefore, the information advisory committees provide will affect agency policy choices. The paper tests this proposition against the alternative argument that advisory committees have no affect on outcomes. To test this proposition, I compiled an original dataset that contains information on every pharmaceutical drug application assessed and voted on by advisory committees in the Food and Drug Administration (FDA) from 2001 to 2008. The paper tests the argument that advisory committees have an informational effect on agency decisionmaking. The evidence from drug regulation indicates that the recommendations of expert committees do have a strong effect on policy outcomes. 
Finally, the third paper examines the historical development of advisory committees in the FDA. In pharmaceutical drug regulation, expertise was difficult to acquire because of rapid advances in drug development, the complexity of assessing safety and efficacy of drugs, limited agency resources, and the competition for qualified personnel. The paper argues that as scrutiny regarding the agency's competence peaked, the leadership of the FDA began to institutionalize information gathering with experts through advisory committees. There is also evidence of a public relations motivation behind the turn to advisory committees. The agency tried to recruit eminent scientists to the permanent staff, but for the most part they failed to acquire them. When the FDA was unable to recruit eminent scientists to their permanent staff, they incorporated them into decisionmaking through consulting arrangements and advisory committees to enhance the credibility of their policy choices.

At present, our knowledge of how agencies generate internal expertise, especially in technical policy areas that require highly skilled labor, is limited. These papers present evidence that agencies do adopt strategies in order to manipulate the costs and benefits of information gathering. I argue that advisory committees are one strategy that the EPA uses to assess the effect of fracking on water contamination and that the FDA employs to improve their assessment of whether a new drug can improve the lives of citizens with a chronic disease. Through these papers, I hope to contribute our understanding of the politics of expertise in bureaucratic agencies. 


\section{Works CITED}

Bawn, Kathleen. 1995. "Political Control Versus Expertise: Congressional Choices About Administrative Procedures." American Political Science Review 89: 62-73.

Epstein, David and Sharyn O'Halloran. 1999. Delegating Powers: A Transaction Cost Politics Approach to Policy Making Under Separate Powers. New York: Cambridge University

Press.

Gailmard, Sean and John W. Patty. 2012. Learning While Governing: Expertise and Accountability in the Executive Branch. Chicago: Chicago University Press.

Gailmard, Sean and John W. Patty. 2007. "Slackers and Zealots: Civil Service, Policy Discretion, and Bureaucratic Expertise." American Journal of Political Science 51: 873889.

Huber, John D. and Charles R. Shipan. 2002. Deliberate Discretion?: The Institutional Foundations of Bureaucratic Autonomy. New York: Cambridge University Press.

Lewis, David E. 2003. Presidents and the Politics of Agency Design. Stanford, CA: Stanford University Press.

Lewis, David E. 2010. The Politics of Political Appointments. Princeton, N.J.: Princeton University Press.

McCubbins, Mathew D., Roger G. Noll, and Barry R. Weingast. 1987. "Administrative Procedures as Instruments of Control." Journal of Law, Economics and Organization 6: 267-298.

McCubbins, Mathew D., Roger G. Noll, and Barry R. Weingast. 1989. "Structure and Process, Policy and Politics: Administrative Arrangements and the Political Control of Agencies." Virginia Law Review 75: 431-482.

Soraghan, Mike. 2011. "Obama Frack Panel to Weigh Link Between Natural Gas Drilling and Health." New York Times, August 16. Accessed June 16, 2013. http://www.nytimes.com/gwire/2011/08/16/16greenwire-obama-frack-panel-toweigh-link-between-natural-7054.html.

Stephenson, Matthew C. 2007. "Bureaucratic Decision Costs and Endogenous Agency Expertise." The Journal of Law, Economics, \& Organization 23: 469-498.

Stephenson, Matthew C. 2011. "Information Acquisition and Institutional Design." Harvard Law Review 124: 1422-1483.

Tavernise, Sabrina, and Katie Thomas. 2013. "F.D.A. to Reconsider Restrictions on 
Diabetes Drug." New York Times, June 2. Accessed June 16, 2013.

http://www.nytimes.com/2013/06/03/business/second-thoughts-on-safety-ofavandia-stir-a-dispute.html.

Tavernise, Sabrina, and Katie Thomas. 2013. "F.D.A. Vote is Minor Victory for Troubled Diabetes Drug." New York Times, June 6. Accessed June 16, 2013. http://www.nytimes.com/2013/06/07/business/fda-advisers-vote-to-liftrestrictions-on-avandia.html.

Volden, Craig. 2002. "A Formal Model of the Politics of Delegation in a Separation of Powers System" American Journal of Political Science 46: 111-133. 


\title{
Generating Expertise or Exerting Political Control: The Use of EXPERT AdVISORY COMMITTEes IN BUREAUCRATIC POLICYMAKING
}

\begin{abstract}
Following their appointment, how do agency secretaries resolve questions of policy uncertainty? Research has recently turned from considering how political actors control bureaucrats to also examining how to incentivize bureaucrats to invest in expertise. This paper argues that in technical policy areas, agency secretaries construct expert advisory committees to lower the costs of expertise acquisition. The alterative hypothesis agency secretaries establish committees as a mechanism for controlling ideologically divergent bureaucrats. The paper statistically tests hypotheses on an original data set of advisory committee creation and renewal (2001-2011). The results from the analysis find strong support for the claim that agency secretaries create advisory committees to augment agency expertise.
\end{abstract}


Executive agencies make critically important policy decisions each day, such as setting clean air and water standards, determining regulations for food production, assessing the safety of pharmaceutical drugs, investigating predatory lending, and regulating who may access natural resources on federal land. To effectively craft policy in these areas, agencies must acquire sufficient information and possess the requisite expertise. Although, research on bureaucratic policy-making has typically assumed that bureaucrats have sufficient expertise and focused on the efforts of Congress and the president to control its use. We need to also examine how administrative expertise is built. ${ }^{1}$ Sean Gailmard and John Patty $(2007,2012)$ argue that political actors (mainly Congress) can incentivize career bureaucrats to acquire expertise through a combination of job security (the civil service system) and policy discretion. However, when policy-making is complex or highly technical, these tools will likely be unable to compel the acquisition of adequate expertise. When prospective or current employees with technical skills possess opportunities in the private sector or elite universities that are more lucrative or bestow greater prestige than the agency can offer, it will be difficult to hire and retain qualified employees. $^{2}$ In these agencies, political actors will adopt additional strategies to improve internal expertise.

Although Congress, the president and the courts each have reason to be concerned with the quality of expertise that is brought to bear on agency decisions, I examine strategies agency

\footnotetext{
${ }^{1}$ Additional research in this vein has considered the manipulation of enactment costs improve information gathering by bureaucrats (Stephenson 2007; Gailmard 2009; Stephenson 2011). ${ }^{2}$ Even for Gailmard and Patty's policy zealots, you can imagine ways for them to affect policy outside of the agency while obtaining more prestige or money. For example, an individual with expertise in some area of medical research can affect the availability of treatments for a particular disease by engaging in research at university hospital or working to develop new drugs at a pharmaceutical company rather than reviewing drug applications at the Food and Drug Administration.
} 
heads adopt to build or maintain the expertise of permanent bureaucratic staff. The behavior of agency secretaries is important because they have both the incentive and authority to adopt strategies to augment internal agency expertise (Carpenter 2001, 2010; Huber 2007). If agency secretaries care about avoiding public policy failure resulting from an inability to understand the relationship between policy instruments and their effects, they will adopt strategies to facilitate the development of expertise among the career bureaucrats.

Studying the strategic behavior of agency secretaries typically poses a challenge because their actions, particularly internal organization decisions, are often hidden from view. However, advisory committees offer a window into strategies that secretaries adopt to address deficits in expertise. Any agency secretary may create an advisory committee, and it is possible to document their usage across agencies. ${ }^{3}$ I argue that agency secretaries construct expert advisory committees when they question the ability of the permanent bureaucratic staff to ascertain the relationship between a policy intervention and its effect in the world. I will test this argument on an original dataset of advisory committee creation and renewal (2001-2011).

In addition, I test this theory against the alternative argument that agency leaders create expert advisory committees to control subordinate bureaucrats. If career bureaucrats and agency secretaries have diverging ideological preferences, agency secretaries can establish committees to minimize information asymmetries between themselves and subordinate bureaucrats. Advisory committees can reduce uncertainty over whether a policy intervention proposed by subordinate bureaucrats reflects their ideological preferences.

The ability of agencies to reduce policy uncertainty and establish sufficient expertise has important implications for the functioning of American government. Agency expertise is

${ }^{3}$ Agencies must charter all advisory committees with the General Services Administration (GSA) every two years. 
necessary if bureaucrats are to translate often vague legislation into concrete policy. However, especially given technological advances and expansions in the breadth of government intervention, agency capacity should not be assumed. Policy expertise must be both built and maintained. This paper is part of an effort to learn more about how agencies cope with expertise problems, and how they balance the need for expertise with that of political control. A study of advisory committee creation, renewal and termination improves our understanding of how agencies go about building capacity when they are unable to recruit the human capital they need.

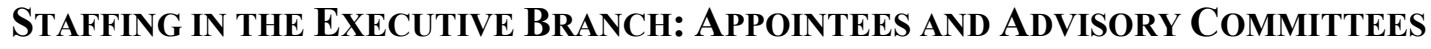

Upon assuming office, a new president is faced with managing a sprawling federal bureaucracy, and must do so within the constraints of the civil service system, which limits his ability to select or dismiss bureaucrats and to pay them differentially. Despite this system, the president is not completely restricted in his ability to staff the bureaucracy with individuals of his choosing. Following each election, presidents appoint approximately 3,000 individuals to positions across the executive branch (Lewis 2010,3). However, their ability to staff the bureaucracy extends beyond appointments. Presidents, and their appointees (once installed) may also create advisory committees. Through these committees, they embed representatives of stakeholder interests as well as external experts into the bureaucratic policy-making process.

The advisory committee system provides an institutional forum in the rulemaking process for consultation with private sector interests and external policy experts. In total, it incorporates approximately 70,000 additional individuals from the private sector, public advocacy groups, research organizations, professional societies, industry representatives, trade groups and academic institutions into the bureaucratic policymaking process ("What is the Composition of 
Committees"). These committees provide an additional mechanism through which political actors can affect agency policy. Over the past decade, there have been approximately 1,000 committees in operation at any given time. Agency secretaries established about half of all committees. $^{4}$

Advisory committees may only provide information; their recommendations do not hold the weight of law. "Determination of action" on their recommendations must be made through the typical policymaking channels (the legislative process, the rulemaking process, or presidential directive) "unless otherwise specified" by Congress or the president (U.S. Public Law 92-463). According to the Federal Advisory Committee Act of 1972 (FACA), advisory committees need to be re-chartered every two years unless statutorily mandated to remain in place. So, if a president or agency leader creates an advisory committee and then leaves office, the incoming department head or president can choose to renew or terminate the committee (U.S. Public Law 92-463). They also have the power to re-staff committees inherited from previous agency secretaries or administrations.

Agencies codify committees on the basis of their composition and purpose. ${ }^{5}$ There are five main categories: 1) grant-making committees, 2) policy issue committees, 3) program committees, 4) negotiated rulemaking committees and 5) scientific technical committees. I will focus on the subset of advisory committees established by agency secretaries and staffed with technical experts (scientific technical committees). In 2012, there were 169 advisory committees

\footnotetext{
${ }^{4}$ For example, in 2010, there were 1,007 committees across 77 agencies, and of those, agency secretaries created 446 of them.

${ }^{5}$ There are also some committees labeled as Special Emphasis Panels. These are mainly in the National Institute of Health (NIH). These panels function similarly to grant-making committees, but some both review grants and give technical recommendations on NIH programs. The main characteristics of each committee can be found in the General Services Administration's Federal Advisory Committee database from 1999 to the present.
} 
constructed by bureau chiefs providing policy recommendations on technical policy issues to bureaucratic decision-makers. The membership of these committees primarily consists of nonstakeholder experts drawn from academia, research institutions, and other areas of the private sector. I have chosen to focus on these committees because they get to the heart of the expertise question.

\section{Administrative Procedure: Information And Control}

Theories of bureaucratic organization have mainly focused on the efforts of Congress and the president to control agency policy through administrative procedure. First, researchers argued that once Congress (the principal) delegates authority to bureaucrats (the agent), they are faced with the challenge of controlling the bureaucrats they empowered (Niskanen 1972). This literature emphasizes that there is an inherent and unavoidable loss to the principal's welfare in delegation due to the problems of moral hazard and adverse selection, and that principals should delegate when the benefits of efficiency and expertise outweigh the losses (McCubbins and Kiewiet 1991). On this account, political actors adopt strategies to limit the ability of career bureaucrats, presidents or future legislative coalitions to move policy away from what political principals prefer (McCubbins and Schwartz 1984; McCubbins, Noll and Weingast 1987, 1989; Epstein and O’Halloran 1999; Huber and Shipan 2002; Lewis 2003, 2010; Volden 2002). These efforts are then reflected in the institutional organization of the bureaucracy because political actors try to bias policy outcomes in their favor by controlling the structure and process of agency decision-making rather than specifying the policy details. ${ }^{6}$ For example, political actors bias decision-making by 1) empowering interest groups (McCubbins and Schwartz 1984;

\footnotetext{
${ }^{6}$ As an alternative to administrative procedure, Congress can also specify the details of policy to a greater degree (Huber and Shipan 2002).
} 
McCubbins, Noll, Weingast 1987, 1989), 2) imposing time limits, reporting requirements or limitation riders on appropriations (Epstein and O'Halloran 1999; McDonald 2010; Carpenter, Chattopadhyay, Moffitt, and Nall, 2012), 3) locking in staff that are supportive of their goals through insulation (Lewis 2003), 4) setting up ineffective decision-making procedures to limit the impact of a policy (Moe 1989) or 5) appointing allies to positions in the bureaucracy to guide policy outcomes (Lewis 2010).

This line of research typically assumes that bureaucratic agencies possess expertise and that the main concern for political principals is controlling the way that agents use their expertise. ${ }^{7}$ However, other researchers have emphasized that expertise is endogenous (Gailmard and Patty 2007, 2012; Stephenson 2007, 2008, 2011; Ting 2009). Stephenson summarizes one main obstacle to the generation of sufficient expertise: "agents' private incentive to invest in research may not align with the social interest in their doing so," and as a result, in questions of institutional design "there is an unavoidable trade-off between inducing optimal use of information ex post and inducing optimal acquisition of information ex ante." (Stephenson 2011, 1426; c.f. Gailmard and Patty 2012, 6) Aside from the noted exceptions, the literature has mainly focused on the former problem - "the optimal use of information"- and only recently come to focus on the latter-the acquisition of information (Stephenson 2011, 1426). This second approach recognizes that information must be acquired, expertise built, and capacity maintained. This complicates our theories of bureaucratic organization.

\footnotetext{
${ }^{7}$ Although expertise is often assumed, the literature does consider the costs of imposing procedural constraints (McCubbins and Kiewiet 1991). For example, Epstein and O'Halloran (1999) argue that Congress will limit the use of procedural constraints like reporting requirements or required consultation with interest groups in highly technical areas. Also, Lewis (2010) and Gallo and Lewis (2012) examine the effects of control strategies on executive branch capacity.
} 
In pursuit of information, expertise, and ultimately competence, political actors may structure institutions in a way that facilitates the development of expertise. Gailmard and Patty (2012) have argued that the "organizational structure and political position of executive branch organizations can decisively affect their members' incentives to make costly investments in information and expertise," so political principals can order agency decision-making to incentivize information gathering and expertise acquisition (Gailmard and Patty 2012,4). As such, we can understand some institutional innovations as mechanisms to promote the development of agency expertise.

Stephenson (2008, 2011), Gailmard (2009), and Gailmard and Patty $(2007,2012)$ focus on institutional mechanisms that increase the marginal benefit of research (typically paid out through policy rewards). ${ }^{8}$ However, when policy research requires specialized knowledge, especially in highly technical fields where the recruitment and retention of employees is difficult, incentivizing through policy rewards may be insufficient. Under these circumstances, political principals may use administrative procedure to affect the marginal costs of additional research for career bureaucrats to reduce policy uncertainty.

\section{ReSEARCH COSTS AND THE USE OF EXPERT AdVISORY COMMITTEeS}

Following their appointment, agency secretaries face uncertainty about 1) the relationship between a proposed policy and its effect in the world and 2) whether the policy reflects their ideological preferences. They need to consider both how to compel career bureaucrats to both acquire the information necessary to make policy decisions and then to use that information in a way that aligns with their preferences. From their position, they have the authority to adopt

\footnotetext{
${ }^{8}$ Stephenson thinks about the way new institutions affect difference between research and default payoff for the bureaucrat (2011).
} 
strategies within the organization to increase the probability that they will achieve their preferred policy outcomes. Agency secretaries, like other political principals, can impose procedural constraints on the bureaucratic agents to limit the ability of bureaucrats to shift policy away from their preferences (McCubbins, Noll and Weingast 1987, 1989; Epstein and O'Halloran 1999; Huber and Shipan, 2002). Alternatively, if they are concerned about agency expertise, they can structure decision-making procedures to increase incentives for career bureaucrats to engage in information gathering (Gailmard and Patty 2007, 2012; Stephenson 2008, 2011). I propose that when policy uncertainty is high, agency secretaries employ expert advisory committees as a mechanism to alter the costs for bureaucrats to acquire expertise.

It is generally accepted that there is an optimal level of research or information acquisition that an agent will engage in or an "optimal stopping problem." (Carpenter 2002) The question for agency leaders becomes how can they induce career bureaucrats to engage in sufficient information gathering, despite the fact that there is a misalignment between the marginal social costs and benefits of information gathering and the bureaucrat's private costs and benefits (Stephenson 2011, 1430; Tullock 1971). ${ }^{9}$

Within the civil service system, agency secretaries are limited in their ability to punish career bureaucrats who fail to sufficiently invest in expertise or to reward those that do. Variable compensation schemes are not permissible and dismissal is difficult. ${ }^{10}$ If a system of financial

\footnotetext{
${ }^{9}$ Stephenson explains that "as a relative matter, the cumulative social utility from making an even slightly better decision on a matter like health care, climate change, counterterrorism, or campaign finance likely dwarfs the private utility that accrues to the responsible decisionmaker."(1431)

${ }^{10}$ Even if a system of financial rewards and punishments were available, principals still face the problem of hidden information. It is difficult to determine whether the agents has engaged in sufficient information-gathering or effort, because the principal cannot easily observe effort or assess the quality of a policy decision, particularly in technical policy areas and when the long term consequences of a policy choice are difficult to discern.
} 
rewards and punishments is unavailable, another option is to alter the marginal private costs and benefits associated with acquiring expertise. As previously noted, existing research emphasizes the use of policy discretion (as a way of increasing the bureaucrat's private benefit of research) in order to incentivize expertise acquisition (Gailmard and Patty 2007; Epstein and O’Halloran 1999; Bawn 1995). Others have emphasized the ways that principals can impose enactment costs on bureaucrats seeking policy rewards (Stephenson 2007, 2008, 2012). For example, political principals, like agency heads or members of Congress, can raise the costs associated with adopting a policy option thus forcing bureaucrats to invest in research in order to realize a policy goal (Stephenson 2007, 2011). Both of these courses involve rewarding bureaucrats with policy gains in exchange for research effort. In both of these examples, principals provide agents policy rewards in exchange for greater information gathering and the development of policy expertise. However, there are other institutional mechanisms that could serve to augment agency expertise.

When policy uncertainty is high and agencies need to acquire expertise to reduce this uncertainty, political principals can manipulate the costs of research effort by establishing expert advisory committees. These committees can improve information gathering through distinct two mechanisms. In the first instance, they can subsidize the private costs of doing additional research (subsidy mechanism), and in the second, they raise the private costs of inadequate research effort (review mechanism). Expert advisory committees typically enter the policymaking process at two distinct points, and the mechanism at work depends on the where in the policy development process they are positioned. First, advisory committees can be called upon to respond to specific requests for information on policy topics or issues that the agency is considering acting upon. Second, they are also often assembled to publicly review and assess the 
research and proposed policies of bureaucrats. The system is even called "peer review" for a group of committees in the Environmental Protection Agency (EPA) and the National Institute of Health (NIH). The former represents a subsidy mechanism and the latter a review mechanism.

I assume that an agency secretary prefers to reduce policy uncertainty and that she recognizes the high costs of developing and maintaining expertise in technical policy areas. When an agency in such a policy area is confronted with a new technical advance or novel class of diseases, drugs, or chemicals to be regulated, agency heads may believe that —even with research effort—career bureaucrats lack the expertise necessary to sufficiently minimize policy uncertainty. In this case, simply providing policy discretion to motivate expertise acquisition may prove insufficient given the time and effort it would take them acquire information. Instead of manipulating the private benefits that accrue to bureaucrats for research, the agency secretary may try to alter the costs associated with acquiring new information.

First, agency secretaries can build institutions that lower the bureaucrat's costs of attaining expertise. Expert advisory committees provide a venue in which agencies can ask a select group of individuals for their input on a new policy issue. Rather than toiling on their own by reading through new research and reaching out to experts independently, advisory committees build into the decision-making process (and a career bureaucrat's regular work day) the acquisition of information on specific policy questions that the bureaucrat is trying to solve. They institutionalize the process of collecting information about specific policy decisions from those with expertise in the relevant area, providing those individuals with the necessary background materials, and obtaining their assessment. In these cases, advisory committees provide an informational subsidy. So, when agencies face policymaking on a new or complex 
problem, the leadership can select the types of experts necessary to assist them on a given policy question and solicit their advice at relatively low cost. ${ }^{11}$

An illustration of this mechanism can be seen in the Center for Medicare and Medicaid Services' (CMS) use of the Medicare Evidence Development and Coverage Advisory Committee (MEDCAC). The committee convenes to assess the effectiveness of new medical advances (procedures, technologies) and then offers advice to CMS on whether Medicare should cover the medical advance in question. This committee regularly incorporates guest members with knowledge bearing on the specific advance in question (Lavertu, Walters and Weimer 2011, 56). The agency solicits information on new advances in technology before deciding how to proceed. The agency does not offer its own assessment prior to soliciting feedback from the committee. In this case, the committee is providing an informational supplement on technical advances prior to developing its own policy assessment. Similarly, the Food and Drug Administration reaches out to their committees on areas of policy they are considering acting on. For example, in April 2008, the Pediatric Subcommittee of the Oncology Committee met to discuss how to enhance global pediatric oncology drug development and the recent European Union legislation governing the development and authorization of medicine for children (Food and Drug Administration 2008). In both cases, agencies are using the committees as a mechanism to lower the costs of information acquisition for career bureaucrats.

Second, agency secretaries who manage agencies with high degrees of policy uncertainty may increase the private costs of inadequate research effort. Although constrained in their

\footnotetext{
${ }^{11}$ On costs, the total cost of running the advisory committee system in 2011 was $\$ 395.2$ million and the system consists of 70, 605 individuals so the per person cost of the system is $\$ 5,597.33$. Of the 70,605 advisory committee members, 1,464 are regular government employees that serve as liaisons between the agency and the committees. So the actual cost per advisory committee member is actually lower (See U.S. General Services Administration, "What is the Composition of Committees"; U.S. General Services Administration, "Spending on Advisory Committees").
} 
ability to offer monitory reward and punishments, they can impose other forms of sanction. Expert advisory committees may accomplish this by introducing a public review or assessment of the work of career bureaucrats. Many expert advisory committees directly review the technical evidence that bureaucrats have assembled in support of a policy decision. In these cases, career bureaucrats research the policy issue in question, present their findings or develop a program, and then the expert panel either directly criticizes the work of the agency's bureaucrats or offers their own assessment of the decision at hand. Either way, the committee is coming in after career bureaucrats have offered their assessment of a policy decision.

If a bureaucrat is policy-motivated and subject to a regular and public review of their policy assessments by a panel of respected external experts, they may be incentivized to engage in research effort for two reasons. First, bureaucrats typically enjoy informational advantages regarding the quality of their work, but when committees composed of well-informed technical experts on the issue in question are assembled to review their work, these advantages are reduced. These external experts can expose inadequate research effort or mistakes that appointees in leadership positions have neither the time nor expertise to identify. If these bureaucrats wish to be trusted with policy discretion or want to preserve a personal reputation that will open career opportunities outside of the agency, then they will want to avoid negative public review. For those bureaucrats motivated by neither esteem nor a desire for policy authority, these reviews will likely do little to improve research effort. However, they may identify those bureaucrats that engage in little research effort and lack expertise.

Second, if some appointed committee members are both technically qualified and have ideological preferences that differ from those of career bureaucrats, advisory committee review can incentivize career bureaucrats to secure verifiable information in support of their preferred 
outcome. In this case, research effort is propelled by bureaucrats' desire to protect their preferred policy choices from being undercut by negative critiques of committee members. Again, if bureaucrats do not possess strong policy preferences and care little if their recommendation is overturned for inadequate evidence, this mechanism will likely fail to incentivize research effort and may in fact increase their incentive to shirk in the hope that committees will pick up their work.

An illustration of the review mechanism can be seen in both pharmaceutical drug and clean air regulation. First, in pharmaceutical drug regulation, the FDA sometimes requests that advisory committees review new drug applications. When committees meet, both the drug firm and FDA bureaucrats present their assessment of the application. Then the agency asks for the committee's feedback on medical officer's and the firm's assessment of the application and whether the drug should be approved. In a second example, in the Environmental Protection Agency (EPA), calls upon an advisory committee - the Board of Scientific Counselors - to provide "advice, information and recommendations about the Office of Research and Development (ORD) research program."12 Again, advisory committees assess tasks already completed by career bureaucrats. The Board of Scientific Counselors examines the work of the career bureaucrats, and makes suggestions in reports that are publicly available on the agency website ("Board of Scientific Counselors Meetings and Reports").

There are costs associated with incorporating advisory committees into the policymaking process. In addition to time and resources spent establishing and maintaining committees, they could increase a bureaucrat's incentive to shirk. It could be that advisory committees will not succeed in augmenting expertise if committee members and permanent bureaucrats are

${ }^{12}$ Quote is obtained from the committee's mission statement on their website (“About BSOC”). 
ideologically close (Ting 2003). ${ }^{13}$ Instead, career bureaucrats will rely on information from outside experts to make decisions, but they will not expend effort themselves or use the forum to augment their own expertise by securing knowledge or attaining a skill that could be applied to future policy decisions.

However, there is reason to believe that collective action problems resulting from the introduction of redundant agents are not deeply problematic in this case. Shirking would be a greater fear if the advisory committees and bureaucrats were simultaneously reviewing a policy question and if their task in the review process was identical (Stephenson 2011, 1462-1464, 1467-1468). The relevant distinctions here are the timing—simultaneous versus sequential—and whether the information produced by committees and permanent bureaucrats are substitutes or complements. Dividing complementary tasks has the potential to enhance an agent's research incentive (Persico 2004) ${ }^{14}$ On timing, either expert committees provide some information on a new policy issue or they review the work already completed by bureaucrats. In either case, they are not duplicating but complementing research assigned to the career bureaucrats. This is not to say that there are not costs that certainly could include reducing the career bureaucrat's incentive for research and the process introduces the potential for information cascades or herding problems (Sunstein 2011; Vermeule 2012). The costs will be particularly high when bureaucrats 1) assign committees tasks that are redundant not complementary, 2) do not possess

\footnotetext{
${ }^{13}$ Advisory committees introduce some redundancy into the policy process, because committees make policy recommendations on the same question that members of the permanent staff are working on. Ting argues that if you assign the same task to at least two agents and these redundant agents have similar ideological preferences, bureaucrats have an incentive to shirk in expectation of the other agent performing the task as they would (Ting 2003, 276). ) He argues that political principal's have an incentive to create redundancy in policymaking when agent's ideological preferences are distant from her own, but when ideological preferences are too close the principal must be concerned about collective action problems (Ting 2003, 276, 287).

${ }^{14}$ Sequential decision-making can lead to gains, but is not without costs. It can lead to problems like information cascades or herd behavior (Sunstein 2011; Vermeule 2012).
} 
strong policy goals, or 3) are not trying to build a reputation in order to open career opportunities for themselves outside of government.

Besides the issue of costs, if an agency secretary is considering establishing advisory committees, three additional questions that are likely to arise: 1) why not augment expertise by building capacity internally, 2) why establish public advisory committees and not use consultants, and 3) are committees an appropriate mechanism of augmenting expertise in every policy domain? First, agencies clearly have an incentive to hire career bureaucrats with the necessary technical skills, but there are several resource-based reasons why agency secretaries may also turn to advisory committees rather than increase expertise by hiring more qualified bureaucrats. ${ }^{15}$ One obvious way that secretaries could lower costs associated with acquiring information is to provide more resources - bigger budgets. Stephenson (2011) argues that this is both socially costly and bureaucrats have only the resourced appropriated to them by Congress. Hiring more and better-qualified bureaucrats also does not address problem of incentive misalignment (1434). Also, agency leaders are typically in their posts for a relatively brief amount of time and supplementing expertise can be done more quickly and at lower costs via advisory committees. Committee members only receive a relatively small per diem and compensation for expenses. While serving, they retain their posts in academic institutions, research organizations or firms. ${ }^{16}$ Finally, the agency would likely have difficulty in recruiting top experts away from positions that provide greater financial remuneration and more esteem

\footnotetext{
${ }^{15}$ Epstein and O’Halloran (1999) argue that Congress faces a "make-or-buy" decision when members must decide whether to write detailed statutes or delegate to the bureaucracy and that if it is too costly to develop the expertise and write detailed statutes that they will delegate (7-8). Agencies face a similar choice when they are forced to consider whether to build a greater informational infrastructure or to draw upon external experts through mechanisms like advisory committees or independent contractors.

${ }^{16}$ In support of this point, Volden (2002) has found that states have turned to policy advisory boards when state financial resources are fewer and governments less professional.
} 
than a position in the civil service could provide. Even if the agency could compete in financial terms, civil service rules limit agencies' ability to take on a group of technical experts while their expertise is in demand, and then they would still face the challenge of incentivizing them to maintain their expertise.

Second, rather than incorporating external experts into the policy process through advisory committees, agency secretaries could just contract with these individuals as private consultants. Technical agencies can and do contract with experts privately. If agencies want to obtain private advice, then consultants are a preferable mechanism for obtaining it. (Unlike advisory committees, the work of consultants is even exempt from Freedom of Information Act requests.) However, these external experts may have a greater incentive to engage in research effort on the policy issue in question when their recommendations are made public. If their advice becomes associated with a policy failure, they could pay a reputational cost. For example, a medical researcher who recommends approval of a drug that turns out to have serious unanticipated harmful effects will likely incur such costs.

As a mechanism for improving agency expertise, expert advisory committees are not equally appropriate across all policy areas. Three points are relevant here: 1) the public nature of advisory committee recommendations make it an inappropriate solution for some types of policy, particularly legal and budgeting strategy, 2) agencies can more easily secure expertise in policy areas where private actors have an incentive to provide it independently, and 3) agencies can more easily secure some types of expertise in house, depending on private sector job opportunities. Therefore, agencies engaging primarily in legal and budgetary policy should rely less on committees, but those agencies relying on scientists and engineers are more likely to bring in external expertise. 
In legal and budgetary policymaking, public discussion would likely hinder an agency's ability to achieve its goals. For example, the Department of Justice will not want to openly discuss and debate what legal strategy to adopt in upcoming cases. However, in other policy areas, this open discussion with experts will be less damaging to the goals of agency leaders. For example, scientists in the Center for Disease Control will want to reduce the uncertainty between a given policy intervention and its effect, and in this context, the aims of the CDC are not harmed by open discussion of the best strategy for combating avian flu or H1N1.

\section{ADDRESSING ALTERNATIVE EXPLANATIONS}

An alternative explanation for the establishment of advisory committees is that agency leaders institutionalize procedural controls to limit the degree to which subordinate bureaucrats can move policy away from their preferred outcomes. Scholars of delegation have long argued that Congress imposes procedural controls on agencies to limit bureaucratic drift, but this same explanation could also apply to agency leaders (McCubbins, Noll, Weingast, 1987, 1989;

McCubbins and Schwartz 1984; Epstein and O'Halloran 1999). ${ }^{17}$ Agency secretaries will need to consider whether career bureaucrats will implement the policies they would have given the same information. We know that the ideological preferences of career bureaucrats and agency secretaries often differs (Clinton et al. 2012; Aberbach and Rockman 2000; Golden 2000) and can assume that career bureaucrats possess more information about the details of policy than do agency secretaries. So, advisory committees could be an institutional strategy to minimize information asymmetries between agency leaders and subordinate bureaucrats by empowering

\footnotetext{
${ }^{17}$ There is extensive literature on when Congress and the president will impose procedures constraints on agencies and the effects of those procedures on policy outcomes: Epstein and O'Halloran 1999; Bawn 1995; Huber and Shipan 2002; Volden 2002; McDonald 2010; Balla 1998; Yackee and Yackee 2006; Farhang 2010; Carpenter, Chattopadhyay, Moffitt and Nall 2012; Farhang 2010; Lewis 2003, 2010.
} 
trusted external experts to monitor their decisions. Balla and Wright (2001) have argued that Congress mandates the use of advisory committees to control the content and flow of information available to agencies in policymaking.

If political control is the primary motivation for incorporating expert advisory committees into policymaking, then as the ideological distance between agency heads and career bureaucrats increases the probability of creating and renewing an advisory committee should also increase. The empirical analysis will directly test this possibility with three different measures of agency ideology and ideological conflict.

\section{HYPOTHESES TO BE TESTED}

The empirical analysis will test the following competing hypotheses:

Information: Agency secretaries construct expert advisory committees to reduce uncertainty about the likely effects of a policy choice. As the work of the agency becomes more technical, agency secretaries are more likely to establish a new expert advisory committee and renew an existing committee. They will also be less likely to terminate an existing committee.

Political Control: Agency secretaries construct advisory committees to reduce information asymmetries between themselves and ideologically divergent career bureaucrats. As the ideological preferences of agency appointees and career bureaucrats diverge, agency secretaries are more likely to establish a new expert advisory committee and more likely to renew an existing committee. They will also be less likely to terminate an existing committee.

I argue that the empirical test will uphold the Information hypothesis, and that advisory committee generation is driven by the need to improve the information brought to bear on policy decisions not by a need to exert political control over ideologically divergent career bureaucrats.

In addition, the analysis will examine whether agencies engaged in some types of policy work are more likely to establish committees than others. I will also examine the following claim: 
Policy Type: Agency secretaries will be more likely to establish advisory committees when policy involves expertise in the biological sciences, physical sciences, mathematical sciences, social sciences, and engineering. They will reach out less consistently when agencies consist mainly of medical professionals, depending on whether medical expertise is used for patient practice or for policy. Finally, they will be unlikely to reach out publicly for additional legal or budgetary expertise.

\section{The EMPIRICAL TEST}

To test the competing explanations, I have constructed a dataset that includes every advisory committee that was established, renewed, and terminated in a federal agency between 2001 and 2011. From this data, I established a count of technical advisory committees created and renewed by agency for each year (See Appendix A for a more detailed explanation of coding protocol). As previously stated, the analysis for this paper includes only those expert or technical committees established by agency secretaries — setting aside committees created by presidents and members of Congress as well as all committees of stakeholder interests. The count of newly created and renewed advisory committees by agency and year will serve as the dependent variable in the three sets of statistical models below. For the analysis, I exclude agencies with less than 100 employees as well as defense and foreign policy agencies. ${ }^{18}$ Defense and foreign policy agencies are not required to report the existence of advisory committees engaged in work on classified materials. Given this exemption, the counts that I have established are incomplete for those agencies doing classified policy-making.

Table 1 displays the average number of total committees and new committees created by agency secretaries, and Table 2 presents the distribution of committees across cabinet departments and large agencies.

\footnotetext{
18 The analysis excludes the Department of Defense, Department of Army, Department of Navy, Department of Air Force, Central Intelligence Agency, and the Department of State.
} 
Table 1. Patterns in Advisory Committee Generation

\begin{tabular}{|l|c|c|c|c|}
\hline \multicolumn{1}{|c|}{ Variable } & Mean & $\begin{array}{l}\text { Standard } \\
\text { Deviation }\end{array}$ & Min & Max \\
\hline $\begin{array}{l}\text { Sum of Advisory } \\
\text { Committees }\end{array}$ & 488 & 15 & 458 & 511 \\
\hline $\begin{array}{l}\text { Sum of New } \\
\text { Committees }\end{array}$ & 36 & 11 & 21 & 59 \\
\hline $\begin{array}{l}\text { Technical } \\
\text { Committees }\end{array}$ & 182 & 8 & 168 & 190 \\
\hline $\begin{array}{l}\text { New Technical } \\
\text { Committees }\end{array}$ & 11 & 5 & 5 & 23 \\
\hline $\begin{array}{l}\text { Terminated } \\
\text { Committees }\end{array}$ & 37 & 15 & 11 & 66 \\
\hline $\begin{array}{l}\text { Terminated } \\
\text { Technical } \\
\text { Committees }\end{array}$ & 12 & 7.5 & 3 & 31 \\
\hline
\end{tabular}

Table 2. Average Sum of TeChnical Advisory Committees Established by Cabinet Departments And Large AgenCies (2001-2011)

\begin{tabular}{|l|c|c|}
\hline Agency & Technical Committees & Sum of Committees \\
\hline Health and Human Services & 86.1 & 175.7 \\
\hline Defense & 11.1 & 32.5 \\
\hline Energy & 9.8 & 16.5 \\
\hline Transportation & 8.2 & 16.5 \\
\hline $\begin{array}{l}\text { Environmental Protection } \\
\text { Agency }\end{array}$ & 6.4 & 14.6 \\
\hline Interior & 5.6 & 21.6 \\
\hline Agriculture & 5.5 & 25.9 \\
\hline Commerce & 5.2 & 21.0 \\
\hline Veterans Affairs & 5.0 & 9.6 \\
\hline Homeland Security & 2.8 & 8.8 \\
\hline National Science Foundation & 2.2 & 3.2 \\
\hline State & 2.0 & 14.5 \\
\hline Social Security Administration & .6 & .6 \\
\hline Education & .4 & 1.2 \\
\hline Justice & .3 & 3.4 \\
\hline Treasury & .2 & 8.0 \\
\hline Securities \& Exchange & & .2 \\
Commission & .2 & 1.2 \\
\hline Labor & .1 & 0 \\
\hline $\begin{array}{l}\text { Housing and Urban } \\
\text { Development }\end{array}$ & 0 & 13.0 \\
\hline Small Business Association & 0 & \\
\hline
\end{tabular}


As you can see, the committees are not in randomly distributed throughout the federal bureaucracy, but concentrated in certain departments and agencies. Furthermore, the creation of new committees and termination of old committees are not evenly distributed across time.

Figure 1 highlights the patterns over time of committee generation.

Figure 1. AdVISORY COMmitTEe Generation AND TERMinATION OVER TIME

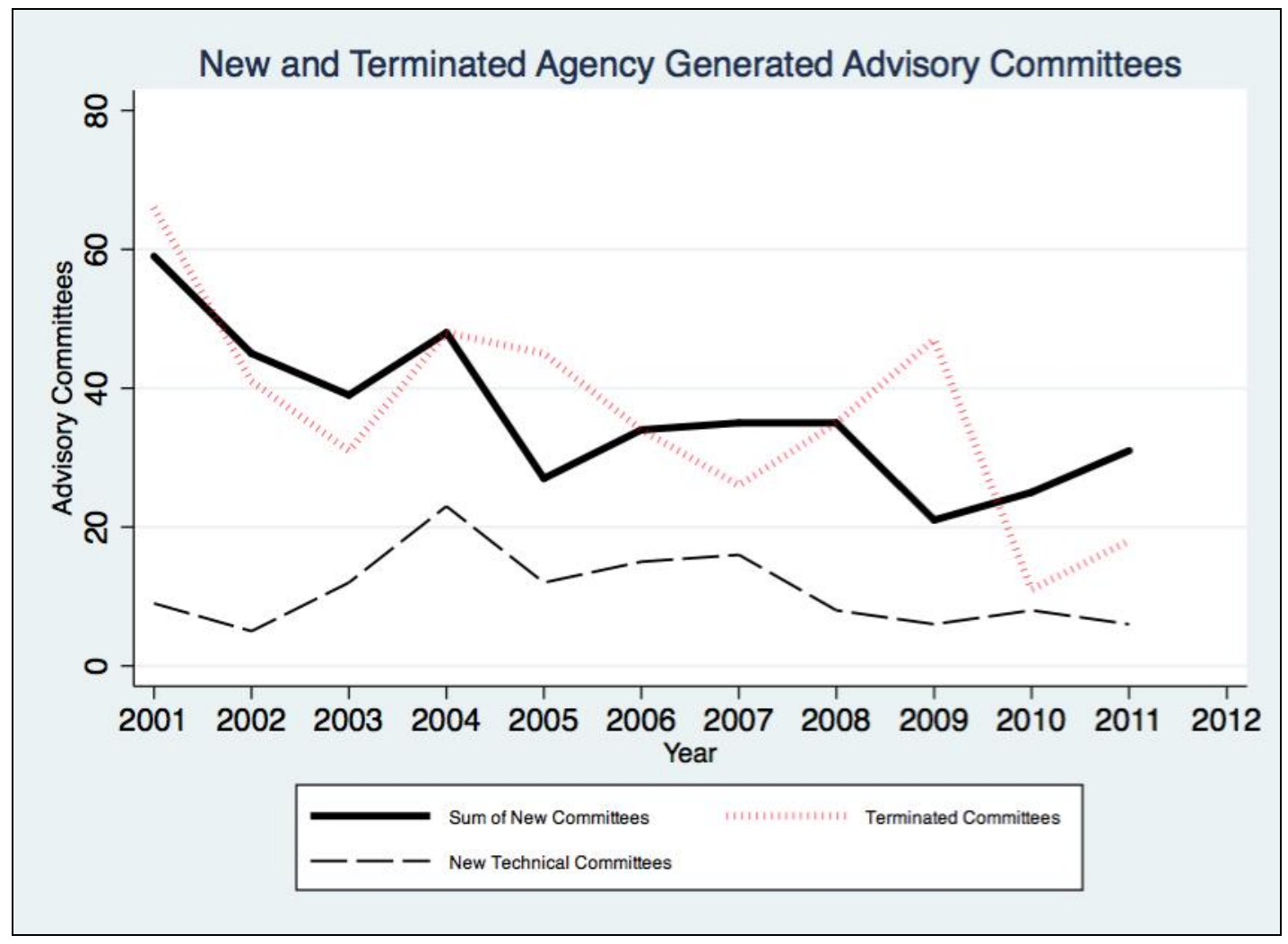

EVALUATING THE INFORMATION ARGUMENT: TECHNICALITY OF POLICY WORK

Concern with developing agency expertise will be more acute when policy relevant expertise is difficult to acquire and maintain. Therefore, those agency secretaries who rely on a more highly trained and technical staff will be more likely to adopt strategies aimed at developing and sustaining that expertise. In contrast, agencies whose staffs are mainly 
administrators or clerks are less likely to be crafting the type of policy where there is uncertainty about its effects. As a result, maintaining adequate expertise in these cases is less challenging. So, if agency secretaries create advisory committees primarily to augment expertise in technical policy areas, then the probability of creating a technical advisory committee will increase as the percent of staff engaged in technical work increases. Similarly, agency secretaries will be more likely to renew committees in agencies where the policy work is more technical.

One reasonable proxy for technicality of policymaking is a measure of agency staff qualifications (Lewis 2010). The Office of Personnel Management (OPM) categorizes every federal employee into five types: professional, administrative, clerical, technical, blue-collar, and unknown ("Fedscope Database"). Of these five types, 'professional' and 'technical' employees are a reasonable proxy for the technicality of agency policymaking. The OPM defines professional employees as being in possession of "knowledge in a field of science" or having education or training "with major study in or pertinent to the specialized field." ${ }^{, 19}$ Technical employees serve as the support staff of professional employees, but their work is considered "non-routine in nature" and "involves extensive practical knowledge." ("The Guide to Data Standards")

The variable used in the analysis is the percent of professional and technical employees in an agency. There is substantial variation across agencies on this dimension with the mean value at 39 percent and standard deviation 19 percent with the range extending from 11 percent to 78

\footnotetext{
${ }^{19}$ A position categorized as 'professional' "requires the exercise of discretion, judgment, and personal responsibility for the application of an organized body of knowledge that is constantly studied to make new discoveries and interpretations, and to improve the data, materials, and methods." ("The Guide to Data Standards") For examples of positions labeled as 'professional' or 'technical', see Appendix A.
} 
percent. I expect that those agencies with higher percent of professional and technical employees will be more likely to construct new and renew existing expert committees.

EVALUATING the Political Control ARGUMENT: IDEOLOGICAL DIVERGENCE

If agency leaders establish expert advisory committees as a mechanism for political control, then they should be more likely to create committees when supervising ideologically divergent career bureaucrats. When career bureaucrats and agency secretaries possess the same policy goals, they need not fear that bureaucrats will use information asymmetries to their advantage. But as ideological difference increases, the secretaries should be more likely to establish new expert advisory committees. I will test both whether ideology has an independent effect on advisory committee creation and renewal and whether there is an interactive effect between the technicality of agency policymaking and ideological divergence. The intuition behind the interactive effect is that the effect of technicality may increase when ideological conflict increases.

Estimating ideological difference between career bureaucrats, and presidents or their appointees across the vast federal bureaucracy is a challenge for researchers. In the analysis that follows, I use three different measures to capture ideological difference: 1) an expert survey of agency ideology (Clinton and Lewis, 2008), 2) a survey of career bureaucrats' support for the agency leaders' goals (“Federal Employee Viewpoints Survey” 2004, 2006, 2008, 2010, 2011) and 3) a survey of appointees and career bureaucratic managers that establishes ideal point estimates (Clinton, et al. 2012). ${ }^{20}$

Clinton and Lewis (2008) developed the first ideology estimate by surveying 23 experts in American bureaucratic politics. The sample includes academics, journalists, and Washington

${ }^{20}$ The ideology estimates vary in the number of agencies and years that there are available. So the sample size for the analysis will change the ideology estimate included in the model. 
think tanks. Those experts received a list of 82 departments and were asked to identify each agency as "slant liberal", "neither consistently", or "slant conservative". I will operationalize ideological different by assuming appointee ideology reflects that of the president. ${ }^{21}$ This tests whether as presidential and agency ideology diverge, agency leaders are more likely to establish advisory committees. ${ }^{22}$

The second measure captures ideological difference by using the Federal Employee Viewpoint Survey (FEVS). The Office of Personnel Management (OPM) administers a survey to capture the opinion of federal employees (career bureaucrats) across a range of executive departments and agencies. The variable Career Support is the sum of employees who either 'Strongly Agree' or 'Agree' with the following survey question in FEVS: "How satisfied are you with the policies and practices of your senior leaders?". 23 If agency leaders establish advisory committees as a mechanism of political control, the probability of advisory committee creation should increase as career bureaucrat support for "policies and practices" of the agency's leader declines.

Third, Clinton, Bertelli, Grose, Lewis, and Nixon (2012) developed a measure of agency ideology that breaks down agency ideology into two components - career bureaucrats and agency appointees. In 2007 and 2008, they directly surveyed 7,448 administrators and program

\footnotetext{
${ }^{21}$ The extent to which this assumption is true varies and sometimes presidents appoint individuals who are ideologically distinct (Bertelli and Grose 2009, 2011).

${ }^{22}$ This is the same approach that Lewis (2010) employed when testing the effect of ideological difference on the creation of additional agency appointees.

${ }^{23}$ The survey question of asked in 2004, 2006, 2008, 2010, 2011. To establish data points for the missing data points, I average the results of the prior and post survey results. For the year 2003, I repeat the data point from 2004.
} 
managers (both appointed and career) about 14 policy issues voted on by Congress in $2006 .^{24}$

From their answers to these policy questions, they derive ideal point estimates for each

individual. ${ }^{25}$ From this measure, it is possible to calculate the ideological difference between the two. Although estimates were developed to make inferences about the 2006-2006 Congress, I make the assumption that the differences between career and appointments do not change greatly over a single presidential administration and use the estimates to assess how ideological difference affects advisory committee creation during the Bush administration. For models using this measure, the sample will be restricted to 2001-2008.

It is also likely that if political control is the driving the establishment of a new expert advisory committee, new committees will be more likely following a presidential transition. You would imagine that if committees are created to fulfill informational needs, these needs should not vary across a presidential administration, but if they are used as a control mechanism, they will be created mostly early in an administration. To capture this, I estimate the effect of a new presidential administration with the Transition variable.

\section{OTHER CONTROL VARIABLES}

The models that follow also contain several important control variables. I include estimates of agency characteristics that also likely affect the decision to create and renew an advisory committee, including agency size (number of employees), and agency structure (whether the agency is a commission or not). ${ }^{26}$ I also include a dummy variable for presidential

\footnotetext{
${ }^{24}$ The response rate was 33\%, but lower for the highest level of appointees. 59\% of respondents were Democrats, which is a reasonable correspondence to the likely partisan composition of the federal bureaucracy.

${ }^{25}$ They are able to place bureaucrats on a scale comparable with presidents and members of Congress.

${ }^{26}$ I take the log of the Employees variable, because there is a strong positive skew in the data. After taking the log, the data more closely approximates a normal distribution.
} 
administration to capture any differences between the executive leadership of President George W. Bush and President Barack Obama. Finally, I also include a dummy variable for divided government. Table 3 contains a brief explanation of all variables and their summary statistics.

\section{TABLE 3. VARIABLES AND SUMmary STATISTICS}

\begin{tabular}{|c|c|c|}
\hline Variable & Description & $\begin{array}{c}\text { Mean } \\
\text { (Standard } \\
\text { Deviation) } \\
\end{array}$ \\
\hline $\begin{array}{l}\text { New Technical } \\
\text { Committees }\end{array}$ & $\begin{array}{c}\text { A yearly count of new technical committees by } \\
\text { agency }\end{array}$ & $\begin{array}{l}.18 \\
(.75)\end{array}$ \\
\hline $\begin{array}{c}\text { Professional Technical } \\
\text { Employees (\%) }\end{array}$ & $\begin{array}{c}\text { Percent of agency employees categorized as } \\
\text { "professional" or "technical” by General Services } \\
\text { Administration }\end{array}$ & $\begin{array}{l}.39 \\
(.19)\end{array}$ \\
\hline $\begin{array}{c}\text { Agency Ideology } \\
\text { (Clinton-Lewis Expert } \\
\text { Survey) } \\
\end{array}$ & $\begin{array}{c}\text { Ideology measure established by an expert survey; } \\
\text { ranges from - } 1 \text { to } 1\end{array}$ & $\begin{array}{l}-.08 \\
(.83)\end{array}$ \\
\hline Bush & $\begin{array}{c}\text { Equals } 1 \text { if George W. Bush is president, } 0 \\
\text { otherwise }\end{array}$ & $\begin{array}{l}.73 \\
(.44)\end{array}$ \\
\hline $\begin{array}{c}\text { Career Bureaucrat } \\
\text { Support (Federal } \\
\text { Employee Viewpoint } \\
\text { Survey) } \\
\end{array}$ & $\begin{array}{l}\text { Percent that are satisfied or very satisfied with } \\
\text { policies of senior leaders (2004-2011) }\end{array}$ & $\begin{array}{l}41.57 \\
(7.14)\end{array}$ \\
\hline $\begin{array}{c}\text { Career-Appointee } \\
\text { Ideology Difference } \\
\text { (Clinton Bertelli Grose } \\
\text { Lewis Nixon) } \\
\end{array}$ & $\begin{array}{l}\text { Survey-based measure that assesses the ideology of } \\
\text { career and appointed bureaucrats by asking their } \\
\text { opinion on legislation in Congress }\end{array}$ & $\begin{array}{l}.53 \\
(.45)\end{array}$ \\
\hline Divided Government & $\begin{array}{l}\text { Equals } 1 \text { if either house of Congress and Presidency } \\
\text { are held by different parties, } 0 \text { otherwise }\end{array}$ & $\begin{array}{l}.46 \\
(.49)\end{array}$ \\
\hline Employees (log) & Natural $\log$ of the number of agency employees & $\begin{array}{l}7.68 \\
(2.17)\end{array}$ \\
\hline Commission & $\begin{array}{c}\text { Equals } 1 \text { if agency is an independent commission, } 0 \\
\text { otherwise }\end{array}$ & $\begin{array}{l}.46 \\
(.49)\end{array}$ \\
\hline Transition & $\begin{array}{l}\text { Equals } 1 \text { in the first year of a presidential } \\
\text { administration, } 0 \text { otherwise }\end{array}$ & $\begin{array}{l}.29 \\
(.45)\end{array}$ \\
\hline
\end{tabular}


In a second set of models, I evaluate the proposition that the type of policy expertise an agency seeks will affect a secretary's decision to create a new committee. Agencies will be more likely to establish committees when the policymaking requires expertise in the biological, physical, mathematical, and medical sciences and engineering. In contrast, budgetary politics and legal strategy are a less appropriate venue for augmenting expertise through advisory committees. In order to evaluate these claims, I break down the percent of professional and technical employees by policy type: 1) Biological and Physical Scientists, 2) Engineers and Mathematicians, 3) Legal Positions, 4) Medical Sciences 5) Social Scientists, and 6) Budgetary Analysts. ${ }^{27}$ Table 4 displays the summary statistics for these variables.

Table 4. Policy Type VAriables and Summary Statistics

\begin{tabular}{|l|l|c|c|}
\hline \multicolumn{1}{|c|}{ Variable } & \multicolumn{1}{|c|}{ Description } & $\begin{array}{c}\text { Mean } \\
\text { (Standard } \\
\text { Deviation) }\end{array}$ & Range \\
\hline $\begin{array}{l}\text { Biological and Physical } \\
\text { Science Employees }(\%)\end{array}$ & $\begin{array}{l}\text { Percent of federal employees classified as } \\
\text { professional or technical and as biological or } \\
\text { physical scientists by agency }\end{array}$ & $\begin{array}{c}2.6 \% \\
(5.8)\end{array}$ & $0-26.8 \%$ \\
\hline Math and Engineering & $\begin{array}{l}\text { Percent of federal employees classified as } \\
\text { professional or technical and as } \\
\text { Employees }(\%)\end{array}$ & $\begin{array}{c}4.4 \% \\
(10.0)\end{array}$ & $0-56.0 \%$ \\
\hline Medical Science & $\begin{array}{l}\text { Percent of federal employees classified as } \\
\text { professional or technical and as medical } \\
\text { Employees }(\%)\end{array}$ & $\begin{array}{l}1.3 \% \\
(5.5)\end{array}$ & $0-33.3 \%$ \\
\hline Scientists by agency & $\begin{array}{l}3.9 \% \\
(10.1)\end{array}$ & $0-65.6 \%$ \\
\hline Employees $(\%)$ & $\begin{array}{l}\text { Percent of federal employees classified as } \\
\text { professional or technical and as social } \\
\text { scientists by agency }\end{array}$ & $\begin{array}{l}3.1 \% \\
(4.3)\end{array}$ & $0-27.8 \%$ \\
\hline Budget Employees $(\%)$ & $\begin{array}{l}\text { Percent of federal employees classified as } \\
\text { professional or technical and as budgetary } \\
\text { analysts by agency }\end{array}$ & $\begin{array}{l}10.6 \% \\
(15.0)\end{array}$ & $0-58.2 \%$ \\
\hline Legal Employees $(\%)$ & $\begin{array}{l}\text { Percent of federal employees classified as } \\
\text { professional or technical and as legal } \\
\text { employees by agency }\end{array}$ & & \\
\hline
\end{tabular}

${ }^{27}$ See Appendix A for details of the types of positions that fall into each of these categories. In the analysis, I will take the log of each to correct for the strong positive skew in the data. 
In summary, I will test whether agency leaders establish new advisory committees and renew existing committees primarily to (1) augment agency expertise by lowering the costs of its acquisition, or (2) control ideologically divergent subordinates by reducing information asymmetries. The first two sets of tables test these propositions. Then, given that it is unlikely that advisory committees are an equally appropriate mechanism for augmenting expertise across policy areas, I drill down into the variable capturing the technicality of agency policy work in the third set of models. These models examine the types of policy expertise that drive agency secretaries to reach out to external experts.

\section{RESULTS}

\section{ADVISORY COMMITTEE CREATION MODELS}

The dependent variable is a count and overdispersion is likely so I use a negative binomial model. Given the time series and cross sectional components of the data, I use a random effects estimator. ${ }^{28}$ The results for the advisory committee creation models are presented first and the models for advisory committee renewal follow.

\footnotetext{
${ }^{28}$ In choosing an appropriate model with panel data, there are several relevant factors. First, in panel data, you can have two types of variation - between and within. Between variation is variation between units $(i)$ or in this case the agencies, and within variation is variation over time $(t)$. The data in this case has both types of variation so I need a model is able to estimate both types variation. Given this, the two main modeling options are the population averaged (PA) estimator (also called generalized estimating equations approach) and the random effects model (RE) (also called error components model). A fixed effects (FE) model is inappropriate, because it will not allow you to estimate the between variation (time invariant variables) accurately. Second, the type of panel - short versus long - is also relevant. A panel is short if the number of units $(i)$ is greater than time unit $(t)$. The data in this case is a short panel, and in short panels, the FE model can lead to inconsistent estimates of coefficients. Since the units are not independent observations over time, a random effects model estimates a random effect for the unit or in the case agency (Wooldridge 2010, 291-310).
} 
Table 5. Advisory Committee Creation: Random Effects Negative Binomial Model

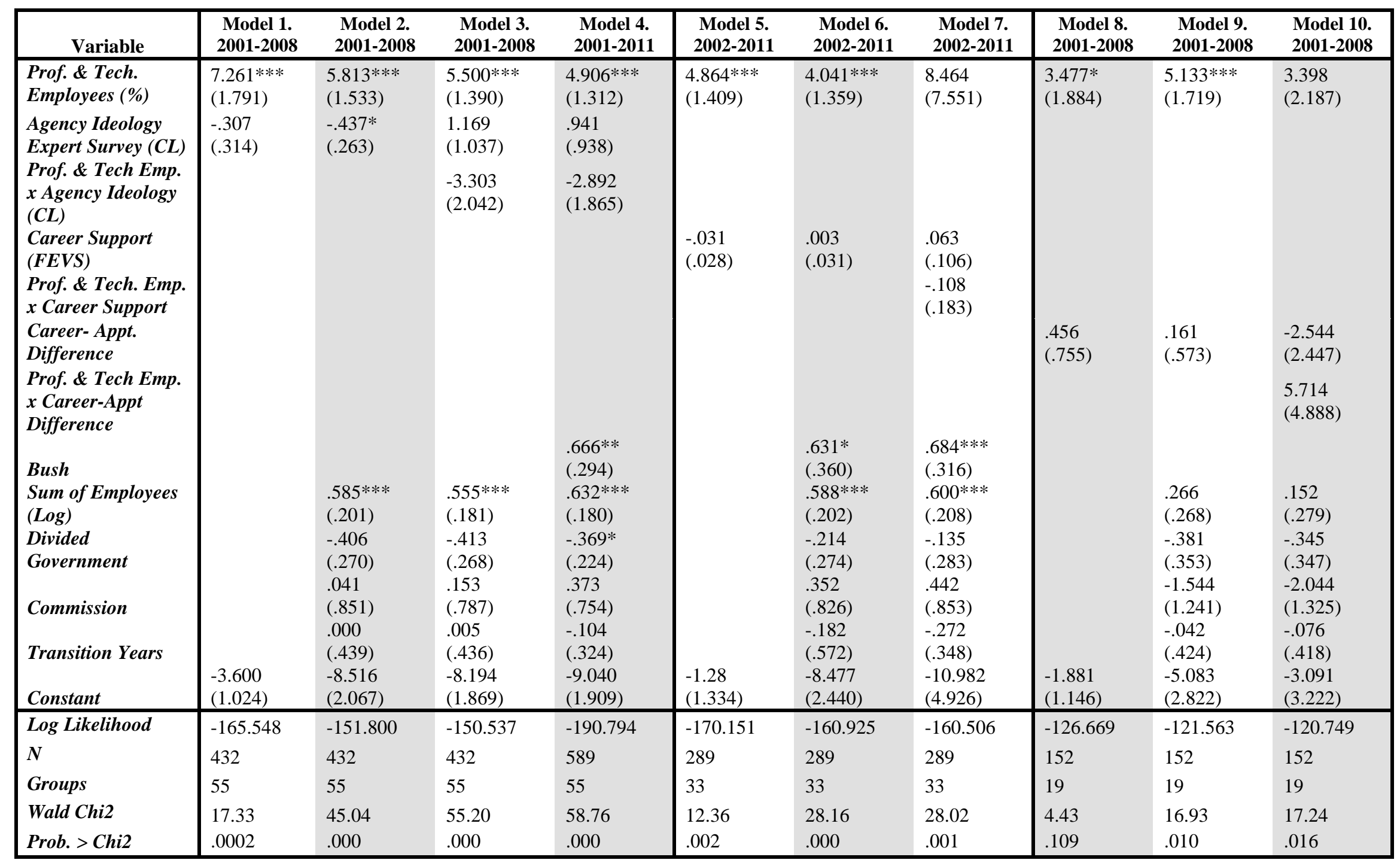

$*$ Variable is significant at the .10 level $* *$ Variable is significant at the .05 level $* * *$ Variable is significant at the .01 level 
As previously noted, I assess the political control argument by including three different estimates of ideological difference. Table 5 is segmented by the political control variable used. Models 1 through 4 include the Agency Ideology Expert Survey variable, models 5 through 7 include the Career Support variable, and finally models 8 through 10 include the CareerAppointee Difference variable. Depending on the political control variable used, the size of the sample changes. Each estimate of agency ideology differs in the number of agencies included. The estimates also cover different time spans. To ease in the interpretation of the models I have included the time frame of the sample at the head of each column. The number of agencies for a given model is displayed in the row entitled 'groups'.

In Models 1 through 3, I assess the affect of Agency Ideology Expert Survey and Professional \& Technical Employees on the decision to create a new committee from 2001 to 2008. Given the president is a Republican and his political appointees likely reflect his preferences, then we should see appointees creating more committees in liberal agencies. ${ }^{29}$ If this is the case, the Agency Ideology variable should be negative and significant. Although the coefficient is negative, it does not approach significance. However, the technicality of agency policymaking does affect the decision to create a new advisory committee. When the control variables are added in Model 2, Professional \& Technical Employees is still positive and significant. With all other variables set at their means and the Professional \& Technical Employees variable is set at one standard deviation below its mean (20\%), the predicted count of committees .038 (.005-.071). When Professional \& Technical Employees increases to its mean value (39\%) the predicted count increases to $.10(.045-.071)$. Then as the variable increases to

\footnotetext{
${ }^{29}$ I make this assumption despite recent evidence that the extent to which appointees ideological preferences reflect those of the president varies (Bertelli and Grose, 2011; Aberbach and Rockman 2000; Golden 2000).
} 
one standard deviation above its mean and then at its maximum, the expected count increases to $.271(.135-.406)$ and $.846(.108-1.584)$ respectively.

Model 3 introduces an interaction between Agency Ideology and Professional \& Technical Employees to assess whether the affect of technicality is contingent on the presence of ideological divergence. Since the significance of interaction terms will depend on the value of the each term, Table 6 calculates the coefficients for different levels of agency ideology.

\section{TABle 6. Estimating THE INTERACTIVE EFFECTS ON ADVISORY COMMITTEe CREATION: Agency Ideology( Expert Survey) X Policy Technicality}

\begin{tabular}{|l|c|c|}
\hline \multicolumn{1}{|c|}{ Interactive Effect } & Model 3. & Model 4. \\
\hline $\begin{array}{l}\text { Effect of Technicality for Most Liberal } \\
\text { Agency (Minimum) }\end{array}$ & $\begin{array}{c}11.181^{* * *} \\
(3.745)\end{array}$ & $\begin{array}{c}9.882^{* * *} \\
(3.391)\end{array}$ \\
\hline Effect of Technicality for I Standard & $\begin{array}{c}8.496 * * * \\
(2.288)\end{array}$ & $\begin{array}{c}7.530^{* * *} \\
(2.077)\end{array}$ \\
Deviation below mean Agency Ideology & & $5.754 * * *$ \\
$(1.395)$ & $5.129 * * *$ \\
Effect of Technicality for Mean Agency & & $3.311)$ \\
Ideology & $\begin{array}{c}3.012 \\
(2.098)\end{array}$ & $\begin{array}{c}2.729 \\
(1.980)\end{array}$ \\
\hline Effect of Technicality for I Standard & -.314 & -.184 \\
Deviation above mean Agency Ideology & $(3.885)$ & $(3.610)$ \\
\hline Effect of Technicality for Most Conservative & & \\
Agency (Maximum) & &
\end{tabular}

*Variable is significant at the .10 level

** Variable is significant at the .05 level

*** Variable is significant at the .01 level

The table demonstrates that the effect of technicality is largest in the most liberal agencies while it has no effect at all in the most conservative agencies. This effect could be driven by the fact that conservative appointees are more likely to create committees in liberal agencies as a mechanism of control or it could be that liberal agencies are more likely to rely on advisory committees. If the effect is driven by ideological difference than the effect should dissipate when the sample is expanded to include the Obama Administration. Model 4 tests this 
proposition. The results are consistent across the two models indicating that it is ideology not ideological difference driving the effect.

In sum, Models 1 though 3 demonstrate that the technicality of policymaking affects the decision to create an advisory committee and that effect is even greater in liberal agencies. These models provide no support for the political control hypothesis, but the models do reveal that technical liberal agencies create committees more often than do conservative technical agencies. The predicted count of new committees when the agency is at its most liberal and the technicality variable is at the minimum is .005 committees, but as you move to the most technical liberal agencies the expected count increases to .978 committees. In the most conservative agencies, the expected count when technicality is at its minimum is .017 , but as you move to the most technical conservative agency, the expected count is still only .091. The effect of technicality on the decision to create a new committee is much greater in liberal agencies.

Models 5 and 6 estimate the effect of Professional Technical Employees and Career Support on outcomes. In both the baseline model and the model with controls, support from career bureaucrats has no effect on the decision to create an advisory committee while the Professional Technical Employees variable still significantly affects outcomes. Model 7 introduces an interaction term between Career Support and Professional \& Technical Employees to see if the effect of Professional and Technical Employees differs for varying levels of support from career bureaucrats. If agency secretaries create committees to control bureaucrats, then we should see the effect of technicality increase as support from career bureaucrats decreases. Column 1 of Table 7 calculates the interaction coefficient on Professional \& Technical Employees for different levels of Career Support. Evidence suggests that the effect of 
technicality is greatest for moderate to slightly below average levels of career support lending some tentative support for the political control hypothesis.

\section{TABLE 7. ESTIMATING THE INTERACTIVE EFFECTS ON ADVISORY COMMITTEE CREATION: Career Support X Policy Technicality and Career-Appointee Difference X Policy TECHNICALITY}

\begin{tabular}{|c|c|c|}
\hline Interactive Effect & Model 7. & Model 10. \\
\hline $\begin{array}{l}\text { Effect of Technicality for Minimum Level of } \\
\text { Career Bureaucrat Support/ Ideological } \\
\text { Difference }\end{array}$ & $\begin{array}{l}5.756^{*} \\
(3.178)\end{array}$ & $\begin{array}{l}3.540 * \\
(2.114)\end{array}$ \\
\hline $\begin{array}{l}\text { Effect of Technicality for } 1 \text { Standard Deviation } \\
\text { below mean Level of Career Bureaucrat } \\
\text { Support/ Ideological Difference }\end{array}$ & $\begin{array}{c}4.735 * * * \\
(1.800)\end{array}$ & $\begin{array}{l}3.843 * * \\
(1.974)\end{array}$ \\
\hline $\begin{array}{l}\text { Effect of Technicality for Mean Level of Career } \\
\text { Bureaucrat Support/Ideological Difference }\end{array}$ & $\begin{array}{c}3.962 * * * \\
(1.414)\end{array}$ & $\begin{array}{l}6.415 * * * \\
(2.111)\end{array}$ \\
\hline $\begin{array}{l}\text { Effect of Technicality for } 1 \text { Standard Deviation } \\
\text { above Mean Level of Career Bureaucrat } \\
\text { Support/ Ideological Difference }\end{array}$ & $\begin{array}{c}3.189 \\
(2.040)\end{array}$ & $\begin{array}{c}8.986^{* * *} \\
(3.834)\end{array}$ \\
\hline $\begin{array}{l}\text { Effect of Technicality for Maximum Level of } \\
\text { Career Bureaucrat Support/ Ideological } \\
\text { Difference }\end{array}$ & $\begin{array}{c}1.077 \\
(5.235)\end{array}$ & $\begin{array}{l}13.791^{*} \\
(7.731)\end{array}$ \\
\hline
\end{tabular}

Models 8 through 10 estimate the effect of ideological difference between political appointees and career bureaucrats on the decision to create a new committee. Models 8 and 9 demonstrate that, once again, technicality of agency employees has a significant effect on outcomes while ideological distance fails to have an independent effect. When an interaction term between Professional \& Technical Employees and Career-Appointee Difference is introduced, there is evidence that technicality of policymaking affects decision to create a committee for all levels of ideological difference. As the ideological difference increases, the size of the coefficient increases. This could lend some tentative support for both hypotheses. These results are difficult to interpret, because this analysis is on the Bush Administration alone 
and ideological difference is greatest in the most liberal agencies. So, we cannot distinguish between whether this effect is actually being driven by ideological difference. The evidence from Model 4 suggests that this affect is likely driven by ideology.

One might argue that those agencies with established advisory committee systems will be more likely to create a new committee. This could be because they already have the institutional apparatus in place or because they have a history of working with advisory committees. To account for this possibility, I also ran a series of models that include the total number of existing technical advisory committees for each observation (agency-year). (Results are displayed in Appendix B.) The ideological difference or conflict variables still fail to reach significance, and the Professional Technical Employees variable is still highly significant with the coefficient only marginally smaller in size than the coefficients in models without these variables.

In sum, the technicality of agency policymaking consistently affects the decision to create an advisory committee. The coefficient on the Professional and Technical Employees variable is substantial and significant regardless of model specification. The evidence from Model 7 provides some support for the political control hypothesis. The results of Models 3 and 4 indicate that agency ideology is also an important factor affecting the decision to create a committee. Agencies that are liberal and technical are much more likely to establish a committee than one that is conservative and technical. In conclusion, the analysis supports the argument that when agency policymaking is more technical, agency secretaries are more likely to establish a new committee. This finding lends credence to the information hypothesis suggesting that agencies create committees to lower the costs of expertise acquisition.

ADVISORY COMMITTEE RENEWAL MODELS 
Next, I estimate the effects of the same explanatory variables above on the decision to renew an existing advisory committee. For this second set of analysis, I again use a random effects negative binomial model. ${ }^{30}$ The results, displayed in Table 8 , demonstrate the information hypothesis fails to explain advisory committee renewals. The technicality of agency policymaking affects the decision to create a new committee, but not the decision to renew an existing committee. The Professional and Technical Variable is never individually significant, except in Model 4 and 10 where it is also included as an interaction term.

In assessing the effect of the political control variables, there is some minimal support in Model 9. However, agency ideology matters in the Models 1 and 2, but once again the effect is being driven by ideology, not ideological difference. Here it shows that more conservative agencies are less likely to renew an existing committee, which is consistent with the finding above that they were also less likely to create a new committee.

The interaction effects are all null results except for the interaction term between the Professional and Technical Variable and the Career-Appointee Difference variable. ${ }^{31}$ Table 9 shows that the effect of technicality is only present when the ideological difference is minimal. Therefore, when appointees and career bureaucrats agree or are both conservative, the agency is less likely to renew a committee. However, we face the same difficulty as above where in this case we cannot discern whether the effect is the product of ideological difference or ideology.

\footnotetext{
${ }^{30}$ But in this case there are exposure issues - not every observation has the same number of possible outcomes. Negative binomial models assume that $\mathrm{N}$ (the number of possible events are infinite). For committee renewals, this is not the case. (Basically, you cannot renew committees that do not exist.) The finite maximum is the observation's exposure. So to cope with the exposure issue, I include an offset, which adds the log of the total number of possible outcomes to the right hand side variables and constrain the coefficient to 1 for all observations.

${ }^{31}$ See Appendix B for the tables of the null results.
} 
TAble 8. Advisory Committee Renewal: Random EfFects Negative BinOMial Model

\begin{tabular}{|c|c|c|c|c|c|c|c|c|c|c|}
\hline Variable & \begin{tabular}{|l|} 
Model 1. \\
2001-2008 \\
\end{tabular} & $\begin{array}{l}\text { Model } 2 . \\
\text { 2001-2008 } \\
\end{array}$ & \begin{tabular}{|l|} 
Model 3. \\
2001-2008 \\
\end{tabular} & \begin{tabular}{|l|} 
Model 4. \\
2001-2011 \\
\end{tabular} & \begin{tabular}{|l|} 
Model 5. \\
2002-2011 \\
\end{tabular} & \begin{tabular}{|l|} 
Model 6. \\
2002-2011 \\
\end{tabular} & $\begin{array}{l}\text { Model } 7 . \\
\text { 2002-2011 } \\
\end{array}$ & \begin{tabular}{|l|} 
Model 8. \\
2001-2008 \\
\end{tabular} & \begin{tabular}{|l|} 
Model 9. \\
2001-2011 \\
\end{tabular} & $\begin{array}{l}\text { Model 10. } \\
\text { 2001-2011 } \\
\end{array}$ \\
\hline $\begin{array}{l}\text { Prof. \& Technical } \\
\text { Employees (\%) } \\
\text { Agency Ideology } \\
\text { Expert Survey }(\text { CL) } \\
\text { Prof. \& Tech } \\
\text { Employees } x \\
\text { Agency Ideology } \\
\text { (CL) } \\
\text { Career Support } \\
\text { (FEVS) } \\
\text { Prof. \& Tech. } \\
\text { Employees } x \text { Career } \\
\text { Support } \\
\text { Career- Appointee } \\
\text { Difference } \\
\text { Prof. \& Tech } \\
\text { Employees } x \\
\text { Career-Appointee } \\
\text { Difference } \\
\text { Bush } \\
\text { Sum of Employees } \\
\text { (Log) } \\
\text { Divided } \\
\text { Government } \\
\text { Commission } \\
\text { Transition Years } \\
\text { Constant }\end{array}$ & $\begin{array}{l} \\
\\
\\
.017 \\
(.164)\end{array}$ & $\begin{array}{l}.033 \\
(.049) \\
.050 \\
(.060) \\
.179 \\
(.194) \\
\\
-.348 \\
(.505)\end{array}$ & $\begin{array}{l}.021 \\
(.050) \\
.041 \\
(.073) \\
.163 \\
(.196) \\
\\
\\
-.223 \\
(.524)\end{array}$ & $\begin{array}{l}.027 \\
(.043) \\
.046 \\
(.051) \\
.188 \\
(.170) \\
\\
-.282 \\
(.451)\end{array}$ & $\begin{array}{l} \\
\\
\\
-.005 \\
(.301)\end{array}$ & $\begin{array}{l}-.051 \\
(.069) \\
.019 \\
(.059) \\
.048 \\
(.061) \\
.174 \\
(.240) \\
-.019 \\
(.070) \\
.003 \\
(.747)\end{array}$ & $\begin{array}{l}.020 \\
(.028) \\
-.047 \\
(.051) \\
\\
\\
\\
\\
\\
\\
-.046 \\
(.069) \\
.032 \\
(.059) \\
.046 \\
(.061) \\
.227 \\
(.241) \\
-.018 \\
(.070) \\
-1.066 \\
(1.339)\end{array}$ & $\begin{array}{l}.192 \\
(.124) \\
\end{array}$ & $\begin{array}{l}.046 \\
(.055) \\
.047 \\
(.078) \\
.057 \\
(.311) \\
.019 \\
(.088) \\
-.567 \\
(.578)\end{array}$ & $\begin{array}{l}-.740 \\
(.492) \\
\\
1.889 * * \\
(.954) \\
\\
\\
-.013 \\
(.054) \\
.048 \\
(.078) \\
\text { No } \\
\text { solution } \\
.017 \\
(.087) \\
.257 \\
(.643)\end{array}$ \\
\hline $\begin{array}{l}\text { Log Likelihood } \\
\text { N } \\
\text { Groups } \\
\text { Wald Chi2 } \\
\text { Prob. > Chi2 }\end{array}$ & $\begin{array}{l}-218.573 \\
121 \\
20 \\
5.80 \\
.055\end{array}$ & $\begin{array}{l}-217.719 \\
121 \\
20 \\
7.43 \\
.191\end{array}$ & $\begin{array}{l}-217.115 \\
121 \\
20 \\
8.60 \\
.283\end{array}$ & $\begin{array}{l}-301.132 \\
171 \\
20 \\
11.18 \\
.083\end{array}$ & $\begin{array}{l}-245.155 \\
136 \\
19 \\
1.39 \\
.500\end{array}$ & $\begin{array}{l}-244.319 \\
136 \\
19 \\
3.09 \\
.876\end{array}$ & $\begin{array}{l}-243.893 \\
136 \\
19 \\
4.04 \\
.854\end{array}$ & $\begin{array}{l}-176.252 \\
93 \\
15 \\
3.37 \\
.185\end{array}$ & $\begin{array}{l}-175.429 \\
93 \\
15 \\
6.40 \\
.380\end{array}$ & $\begin{array}{l}-173.323 \\
93 \\
15 \\
10.14 \\
.119\end{array}$ \\
\hline
\end{tabular}

$*$ Variable is significant at the .10 level $* *$ Variable is significant at the .05 level $* * *$ Variable is significant at the .01 level. 


\section{TABLE 9. ESTIMATING THE INTERACTIVE EFFECTS ON ADVISORY COMMITTEE RENEWAL: CAREer-A ppointee Difference X Policy TeChNiCAlity}

\begin{tabular}{|l|c|}
\hline \multicolumn{1}{|c|}{ Interactive Effect } & Model 10. \\
\hline $\begin{array}{l}\text { Effect of Technicality for Minimum Level of } \\
\text { Ideological Difference }\end{array}$ & $\begin{array}{c}-.902^{* *} \\
(.398)\end{array}$ \\
\hline $\begin{array}{l}\text { Effect of Technicality for 1 Standard Deviation } \\
\text { below mean Level of Ideological Difference }\end{array}$ & $-.802^{* *}$ \\
$(.371)$ \\
\hline $\begin{array}{l}\text { Effect of Technicality for Mean Level of } \\
\text { Ideological Difference }\end{array}$ & .048 \\
\hline $\begin{array}{l}\text { Effect of Technicality for 1 Standard Deviation } \\
\text { above Mean Level of Ideological Difference }\end{array}$ & $. .406)$ \\
\hline $\begin{array}{l}\text { Effect of Technicality for Maximum Level of } \\
\text { Ideological Difference }\end{array}$ & $(.749)$ \\
\hline
\end{tabular}

*Variable is significant at the .10 level

** Variable is significant at the .05 level

$* * *$ Variable is significant at the .01 level

\section{POLICY TYPE MODELS}

Next, I will examine how policy type affects the decision to create a committee by breaking down the Professional Technical Employee variable. Advisory committees are a reasonably flexible tool, but there are still some policy areas where this strategy is more appropriate than others. Table 10 presents the results of the models that divide the Professional Technical Employees by type of expertise. There are two versions of the model. Model 1 includes only the policy type variables, and then in Model 2, I add the controls.

Consistent with the proposed hypothesis, agencies with more career bureaucrats in engineering, and the biological, physical and mathematical sciences are more likely to turn to advisory committees. The coefficient for medical employees was also positive and highly significant. An increasing presence of legal, budgetary or social scientists has no effect on the decision to create a new technical advisory committee. 
To capture the substantive impact of the estimates, we can again calculate the predicted counts. The presence of biological and physical science employees had a large and significant effect. When the Biological and Physical Science Employees variable is set at its mean (2.5\%), the predicted count of new committees is .11 (.045-.178), but if you set the variable at its maximum, the expected count rises to $.77(.098-1.459)$. These models demonstrate that the effect of policymaking technicality varies across policy areas. 
Table 10. Advisory Committee Generation: Policy Type

\begin{tabular}{|c|c|c|}
\hline Variable & Model 1. & Model 2. \\
\hline $\begin{array}{l}\text { Biological and Physical } \\
\text { Science Employees (\%) }\end{array}$ & $\begin{array}{c}16.306 * * * \\
(2.934) \\
\end{array}$ & $\begin{array}{c}12.224 * * * \\
(2.967) \\
\end{array}$ \\
\hline $\begin{array}{l}\text { Math and Engineering } \\
\text { Employees }(\%)\end{array}$ & $\begin{array}{c}2.895 * * \\
(1.276)\end{array}$ & $\begin{array}{c}2.830 * * \\
(1.300)\end{array}$ \\
\hline $\begin{array}{l}\text { Medical Science Employees } \\
(\%)\end{array}$ & $\begin{array}{c}10.951 * * * \\
(2.175)\end{array}$ & $\begin{array}{l}5.751 * * \\
(2.905) \\
\end{array}$ \\
\hline $\begin{array}{l}\text { Social Science Employees } \\
(\%)\end{array}$ & $\begin{array}{l}-2.442 \\
(2.389)\end{array}$ & $\begin{array}{l}-2.202 \\
(2.248)\end{array}$ \\
\hline Budget Employees (\%) & $\begin{array}{c}4.214 \\
(5.694)\end{array}$ & $\begin{array}{c}2.667 \\
(5.428)\end{array}$ \\
\hline Legal Employees (\%) & $\begin{array}{l}-1.492 \\
(2.477)\end{array}$ & $\begin{array}{c}.866 \\
(2.751)\end{array}$ \\
\hline $\begin{array}{l}\text { Agency Ideology (Expert } \\
\text { Survey) }\end{array}$ & & $\begin{array}{l}-.185 \\
(.271) \\
\end{array}$ \\
\hline Bush & & $\begin{array}{l}.560 * * \\
(.284) \\
\end{array}$ \\
\hline Divided Government & & $\begin{array}{l}-.191 \\
(.242)\end{array}$ \\
\hline Employees (Log) & & $\begin{array}{c}.558 * * * \\
(.199)\end{array}$ \\
\hline Transition & & $\begin{array}{l}-.149 \\
(.282) \\
\end{array}$ \\
\hline Commission & & $\begin{array}{r}.603 \\
(.743) \\
\end{array}$ \\
\hline Constant & $\begin{array}{l}-2.246 \\
(.590) \\
\end{array}$ & $\begin{array}{l}-7.436 \\
(2.103) \\
\end{array}$ \\
\hline Log Likelihood & -197.221 & -187.222 \\
\hline$N$ & 599 & 588 \\
\hline Groups & 56 & 55 \\
\hline Wald Chi2 & 76.34 & 78.29 \\
\hline Prob. > Chi2 & 0.000 & 0.000 \\
\hline
\end{tabular}

$*$ Variable is significant at the .10 level $* *$ Variable is significant at the .05 level *** Variable is significant at the .01 level 


\section{DisCUSSION AND CONCLUSIONS}

This paper aims to make two core points. First, agency leaders, in addition to presidents and members of Congress, actively adopt strategies to pursue their policy goals in the bureaucracy. Second, political principals are not only concerned with controlling ideologically divergent subordinates, but also with developing agency expertise, particularly in technical policy areas where recruitment and retention of qualified personnel is difficult. The presence of agency generated advisory committees throughout the executive branch are just one indication of how active these agency leaders are in trying to shape the information environment of the agencies they manage. Agency secretaries have established hundreds of advisory committees across the federal bureaucracy bringing in thousands of external actors into direct and regular contact with the permanent bureaucratic staff. Research evaluating the effectiveness of congressional procedural controls over the bureaucrats must also consider the ways in which actors within the executive branch also work to structure agency decision-making.

This paper lends support to arguments made by Gailmard and Patty $(2007,2012)$ and Stephenson $(2007,2008,2011)$ that emphasize that expertise is not exogenous, and principals need to consider how to facilitate its development. The organization of bureaucratic decisionmaking can be structured to incentivize the acquisition of information as well as to control potentially divergent agents. If agencies are trying to decrease uncertainty between a policy intervention and its outcome in the world, then the advisory committees can be a mechanism to lower the costs of expertise acquisition necessary to make policy decisions in some areas. The results of the empirical test above confirm that agency secretaries construct advisory committees in those agencies engaging in more technical policy work - not in those agencies where ideological conflict is greatest. I do not claim that these agency secretaries never adopt strategies 
to control subordinate bureaucrats only that when policy is highly technical, they will try to adopt institutional strategies to lower the costs of expertise acquisition. 


\section{WORKS CITED}

Aberbach, Joel D. and Bert A. Rockman. 2000. In the Web of Politics: Three Decades of the U.S. Federal Executive. Washington, D.C.: Brookings Institution Press.

Balla, Steven J. 1998. "Administrative Procedures and Political Control of the Bureaucracy." The American Political Science Review 92: 663-673.

Balla, Steven J. and John Wright. 2001. "Interest Groups, Advisory Committees, and Congressional Control of the Bureaucracy." American Journal of Political Science 45: 799-812.

Bawn, Kathleen. 1995. "Political Control Versus Expertise: Congressional Choices About Administrative Procedures." American Political Science Review 89: 62-73.

Bertelli, Anthony M. and Christian R. Grose. 2011. "The Lengthened Shadow of Another Institution? Ideal Point Estimates for the Executive Branch and Congress." American Journal of Political Science. 55: 766-780.

Bertelli, Anthony M. and Christian R. Grose. 2009. "Secretaries of Pork? A New Theory of Distributive Public Policy." American Journal of Political Science. 71: 926-945.

Cameron, A. Colin and Pravin K. Trivedi. 2010. Microeconometrics Using Stata. College Station, TX: Stata Press.

Carpenter, Daniel. 2010. Reputation and Power: Organizational Image and Pharmaceutical Regulation at the FDA. Princeton, N.J.: Princeton University Press.

Carpenter, Daniel. 2001. The Craft of Bureaucratic Autonomy: Reputations, Network, and Policy Innovation in Executive Agencies, 1862-1928. Princeton, N.J.: Princeton University Press.

Carpenter, Daniel, Jacqueline Chattopadhyay, Susan Moffitt and Clayton Nall. 2012. "The Complications of Controlling Agency Time Discretion: FDA Review Deadlines and Postmarket Drug Safety." American Journal of Political Science 56(1): 98-114.

Clinton, Joshua D., Anthony Bertelli, Christian R. Grose, David E. Lewis, and David C. Nixon. 2012. "Separated Powers in the United States: The Ideology of Agencies, Presidents, and Congress." American Journal of Political Science 56(2): 341-354.

Clinton, Joshua D., and David E. Lewis. 2008. "Expert Opinion, Agency Characteristics, and Agency Preferences." Political Analysis 16(1): 3-20.

Epstein, David and Sharyn O’Halloran. 1999. Delegating Powers: A Transaction Cost Politics Approach to Policy Making Under Separate Powers. New York: Cambridge University Press. 
Farhang, Sean. 2010. The Litigation State. Princeton, NJ: Princeton University Press.

Gailmard, Sean. 2009. "Discretion Rather than Rules: Choice of Instruments to Control Bureaucratic Policy Making." Political Analysis 25: 25-42.

Gailmard, Sean and John W. Patty. 2012. Learning While Governing: Expertise and Accountability in the Executive Branch. Chicago: Chicago University Press.

Gailmard, Sean and John W. Patty. 2007. "Slackers and Zealots: Civil Service, Policy Discretion, and Bureaucratic Expertise." American Journal of Political Science 51: 873889.

Gallo, Nick and David E. Lewis. 2012. " The Consequences of Presidential Patronage for Federal Agency Performance." The Journal of Public Administration Research and Theory 22: 219-243.

Golden, Marissa M. 2000. What Motivates Bureaucrats? Politics and Administration During the Reagan Years. New York: Columbia University Press.

Huber, Gregory A. 2007. The Craft of Bureaucratic Neutrality. New York: Cambridge University Press.

Huber, John D. and Charles R. Shipan. 2002. Deliberate Discretion?: The Institutional Foundations of Bureaucratic Autonomy. New York: Cambridge University Press.

Lavertu, Stephane, Daniel E. Walters, and David L. Weimer. 2011. "Scientific Expertise and the Balance of Political Interests: MEDCAC and Medicare Coverage Decisions.” Journal of Public Administration Research and Theory 22: 55-81.

Lavertu, Stephane and David L. Weimer. 2011. "Federal Advisory Committees, Policy Expertise, and the Approval of Drugs and Medical Devices at the FDA." Journal of Public Administration Research and Theory 21: 211-237.

Lewis, David E. 2003. Presidents and the Politics of Agency Design. Stanford, CA: Stanford University Press.

Lewis, David E. 2010. The Politics of Political Appointments. Princeton, N.J.: Princeton University Press.

McCubbins, Mathew D., Roger G. Noll, and Barry R. Weingast. 1987. "Administrative Procedures as Instruments of Control." Journal of Law, Economics and Organization 6: 267-298.

McCubbins, Mathew D., Roger G. Noll, and Barry R. Weingast. 1989. "Structure and Process, Policy and Politics: Administrative Arrangements and the Political Control of Agencies." 
Virginia Law Review 75: 431-482.

McCubbins, Mathew D., and Thomas Schwartz. 1984. "Congressional Oversight Overlooked: Police Patrols versus Fire Alarms.” American Journal of Political Science 28: 165-179.

McDonald, Jason A. 2010. "Limitation Riders and Congressional Influence over Bureaucratic Policy Decisions." American Political Science Review 104: 766-782.

Moffitt, Susan L. 2010. "Promoting Agency Reputation through Public Advice: Advisory Committee Use in the FDA." The Journal of Politics 72: 880-893.

Persico, Nicola. 2004. "Committee Design with Endogenous Information." Review of Economic Studies 71(1): 165-191.

Sunstein, Cass R. 2011. A Constitution of Many Minds: Why the Founding Document Doesn't Mean What it Meant Before. Princeton, N.J.: Princeton University Press.

Stephenson, Matthew C. 2007. "Bureaucratic Decision Costs and Endogenous Agency Expertise." The Journal of Law, Economics, \& Organization 23: 469-498.

Stephenson, Matthew C. 2008. "Evidentiary Standards and Information Acquisition in Public Law." American Economic Review 10: 351-387.

Stephenson, Matthew C. 2011. "Information Acquisition and Institutional Design." Harvard Law Review 124: 1422-1483.

Ting, Michael M. 2003. “A Strategic Theory of Bureaucratic Redundancy.” American Political Science Review 47: 274-292.

Ting, Michael M. 2009. "Organizational Capacity.” Journal of Law, Economics and Organization 27(2): 245-271.

U.S. Environmental Protection Agency. “About BOSC.” Last modified June 29, 2013: http://epa.gov/osp/bosc/about.htm

U.S. Environmental Protection Agency. "BOSC Reports and ORD Responses." Last modified June 29, 2013: http://epa.gov/osp/bosc/reports.htm

U.S. Food and Drug Administration. 2008. Proceedings of the Pediatric Oncology Subcommittee of the Oncologic Drugs Advisory Committee, April 16, 2008. Washington, D.C.: Paper Mill Reporting.

U.S. General Services Administration. Federal Advisory Committee Database. Last modified 25 January 2013: http://fido.gov/facadatabase/public.asp.

U.S. General Services Administration. "Spending on Advisory Committees." Last 
modified: June 2013 http://www.gsa.gov/portal/content/249013.

U.S. General Services Administration. "What is the Composition of Advisory Committees." Last modified: June 2013 http://www.gsa.gov/portal/content/249049.

U.S. Office of Personnel Management. Fedscope Database. Last modified June 2013: http://www.fedscope.opm.gov/.

U.S. Office of Personnel Administration. 2002. 2002 Federal Employee Viewpoint Survey. Accessed at: http://www.fedview.opm.gov/.

U.S. Office of Personnel Administration. 2004. 2004 Federal Employee Viewpoint Survey. Accessed at: http://www.fedview.opm.gov/.

U.S. Office of Personnel Administration. 2006. 2006 Federal Employee Viewpoint Survey. Accessed at: http://www.fedview.opm.gov/.

U.S. Office of Personnel Administration. 2008. 2008 Federal Employee Viewpoint Survey. Accessed at: http://www.fedview.opm.gov/.

U.S. Office of Personnel Administration. 2010. 2010 Federal Employee Viewpoint Survey. Accessed at: http://www.fedview.opm.gov/.

U.S. Office of Personnel Administration. 2012. 2012 Federal Employee Viewpoint Survey. Accessed at: http://www.fedview.opm.gov/.

U.S. Office of Personnel Management. 2013. Fedscope Data Definitions. Accessed at: http://www.fedscope.opm.gov/datadefn/index.asp.

U.S. Office of Personnel Management. 2013. The Guide to Data Standards Part A: Human Resources. Accessed at: www.opm.gov/feddata/GDS/GDS_A09.pdf.

Vermeule, Adrian. 2012. Law and the Limits of Reason. New York: Oxford University Press.

Volden, Craig. 2002. "A Formal Model of the Politics of Delegation in a Separation of Powers System” American Journal of Political Science 46: 111-133.

Volden, Craig. 2002. "Delegating Power to Bureaucracies: Evidence from the States." Journal of Law, Economics, and Organization 18: 187-220.

Woolridge, Jeffery M. 2010. Econometric Analysis of Cross Sectional and Panel Data. Cambridge, M.A.: MIT Press.

Yackee, Jason Webb, and Susan Webb Yackee. 2006. "A Bias Towards Business? Assessing Interest Group Influence on the U.S. Bureaucracy." The Journal of Politics 68: 128-139. 


\section{APpendix A. Data}

\section{ESTABLISHMENT OF ADVISORY COMMITTEE COUNT:}

I assembled advisory committee count data from the Federal Advisory Committee database. The database can be accessed at: http://www.fido.gov/facadatabase/. The database is managed by the General Service Agency (GSA). Within the electronic database, a list of current advisory committees is listed by agency by year. From this list, I established a count of new, renewed, and terminated committees by year.

In order to establish the year that committees become active, I determine this date by the year that the committee enters the database and then check the date of the current charter for the committee and list of recent meetings. (Committees need to be re-chartered every two years and the current charter date is listed within under the 'Committee Report' section for every advisory committee.) Sometimes, committees only enter the database the year following the actual charter begins so in these cases, they enter the count in the year that their charter begins. In rarer cases, committees enter the database years after their establishment. For these cases, I count the current charter date given for the committee's first entry into the database. If an advisory committee meeting is listed prior to that current charter date, I use the earliest meeting date available. If committees were once active, then terminated, I consider the re-establishment of the committee the same as creating a new committee. If committees were merged and formed under a new name; I count them as a newly formed committee

The committees exit the count of active committees the year that they are terminated. In committee report, the GSA reports the termination date of the committee. Sometimes committees are dropped, but the termination date is not included in their last year in operation. In those 
cases, I consider the last year that the committee is in the database to be the year that the committee was terminated.

The committees can be created by either by executive order or statute as well as through the will of an agency head (typically through an secretarial memorandum). The FACA database codes committee as either: presidential, authorized by law, statutory, or agency. The distinction between authorized by law and statutory is that if the committee is established by statute, then the agency is required to constitute a committee. However, in the case of authorized by law, the agency is not legally bound to create a committee. Therefore, I recoded all 'authorized by law' committees as agency committees since the ultimate decision to create the committee is left in the hands of the agency. All of the committees in the portion of the broader dataset used in this paper are agency-generated committees.

The advisory committee count is also broken down by committee type. The database codes committees as: 1) scientific technical, 2) non-scientific program advisory board, 3) national policy issue advisory board, 4) grant, 5) special emphasis panel, 6) negotiated or 7) other. I re-coded all committees as either: 1) technical, 2) program, 3) issue, 4) grant or 5) negotiated. Many committees coded as 'other' were performing the same function as another committee in the agency that was labeled as technical, grant, program or issue. I used these comparisons and the description of what the committee does and the membership content of the committee to re-label 'other' committees by type.

'Scientific Technical' committees (labeled as TECH committees in the dataset) are committees composed of experts from academia and the private sector. They include only nonvoting representatives of stakeholders or interest groups among their members. They tend to offer review technical programs (like in the Centers for Disease Control) or to oversee the 
regulation of technical products (like chemicals and pharmaceuticals) or where implications of the policy interventions are complicated and implications of interventions are less than certain (like in the Environmental Protection Agency's regulation of clean air and water).

Grant committees primarily distribute federal grant money to private sector, local governments or university recipients. They are often also composed of a technical, academic members, but these committees do not advise of policy intervention only aid in the identification of suitable candidate for the distribution of government research funds.

Committees labeled 'special emphasis' were primarily located in the National Institute of Health. These committees were recoded as either technical or grant depending on whether they were advising on policy technical policy issues or distributing grant money. The technical committees are composed on external experts. They are not representatives of interest groups or active, financial stakeholders in the policy question at stake.

Program committees consist of active stakeholders in a policy area and include representatives of interest groups with a stake in the policy. Program committees actively advise on a current policy program. In contrast, policy issue committees propose policy solution to an issue, rather than advising on the implementation of a particular program. Their recommendations could call for new legislation rather than provide recommendations on the management of an existing policy. Issue advisory committee members are often a mix of stakeholder interests and outside policy experts.

Negotiated committees are distinct from each of the other categories of advisory committees. Typically, advisory committees have only the authority to make recommendations to presidents, members of Congress, and agency leaders. However, in the case of the negotiated 
committees, political actors expressly delegate these negotiated committees the power to make agency policy. They are few in number and are excluded from the dataset.

\section{DEPENDENT VARIABLE:}

TECH = count of active technical expert advisory committees in a given year. See below for a more in depth explanation of how the count of advisory committees was established.

TECHNEW= count of all newly created technical advisory committees in a given year.

TECHRENEW= count of all renewed technical advisory committees in a given year.

\section{UNIT OF ANALYSIS:}

YEAR= year of observation

AGENCYID: each unit of observation or agency is assigned an agency id number.

\section{LEADERSHIP AFFECTS:}

BUSH $=1$ if George $\mathrm{W}$. Bush is president and 0 otherwise.

APPTNEW $=1$ if a new individual is appointed to lead an agency and 0 otherwise.

DIVIDED $=1$ if government is divided by party and 0 is government is unified by party.

\section{EMPLOYEE TYPE:}

All data on employee type is from the Office of Personnel Management (OPM) Fedscope database. Accessed at: www.fedscope.opm.gov. In depth descriptions of variables collected by the OPM can be found in "The Guide to Data Standards," which is consider the operating manual compiled by the OPM for the Fedscope database (http://www.opm.gov/feddata/guidance.asp). 
$\mathbf{E M P}=$ sum of all agency employees.

PROF_EMP= sum of professional employees. The OPM categorizes all employees into the following occupational categories: Blue Collar, Professional, Administrative, Technical, Clerical, White Collar Other. The OPM defines professional employees as: "White collar occupations that require knowledge in a field of science or learning characteristically acquired through education or training equivalent to a bachelor's or higher degree with major study in or pertinent to the specialized field, as distinguished from general education. The work of a professional occupation requires the exercise of discretion, judgment, and personal responsibility for the application of an organized body of knowledge that is constantly studied to make new discoveries and interpretations, and to improve the data, materials, and methods.”( U.S. Office of Personnel Management. 2013, 348) Examples of 'Professional' employees include: Foreign Law Specialist, Social Science, Economist, Foreign Affairs, Microbiology, Pharmacology, Ecology, Forestry, Soil Science, Agronomy, Medical Officer, Nurse, Veterinary Medical Science, General Engineering, Chemical Engineering, General Attorney, Administrative Law Judge, Patent Adviser, Chemistry, Metallurgy, Astronomy, Mathematics, Statistics, Computer Science, or Education Research among others.

TECH_EMP $=$ sum of technical employees. White collar occupations that involve work typically associated with and supportive of a professional or administrative field, that is non-routine in nature; that involves extensive practical knowledge, gained through on-job experience and/or specific training less than that represented by college graduation. Work in these occupations may involve substantial elements of the work of the professional or administrative field, but requires less than full competence in the field involved." 
Examples include: Environmental Protection Assistant, Computer Operation, Equal Opportunity Assistance, Telecommunications Processing, Soil Conservation Technician, Irrigation System Operation, Medical Technician, Animal Health Technician, Engineering Technical, Construction Control Technical, Physical Science Technician, Hydrologic Technician, Patent Technician, Mathematics Technician, Cartographic Technician, Food Inspection, Agricultural Commodity Grading, or Air Navigation. PROFTECH= sum of Professional and Technical Employees

PROFTECPCT $=$ percent of agency employees that are Professional and Technical Employees

PROFTECHPCTLOG $=$ the natural $\log$ of $1+$ PROFTECHPCT SOCSCI_EMP= sum of professional social science employees. Category includes positions labeled as: Social Science, Economist, Foreign Affairs, International Relations, Foreign Agricultural Affairs, Workforce Research and Analysis, Geography, History, Psychology, Sociology, Social Work, General Anthropology, and Archeology. BIO_EMP = sum of professional biological sciences and natural resource management employees. Includes individuals in positions labeled as: General Natural Resources Management and Biological Science, Microbiology, Pharmacology, Ecology, Zoology, Physiology, Entomology, Toxicology, Botany, Plant Pathology, Plant Physiology, Horticulture, Genetics, Rangeland Management, Soil Conservation, Forestry, Soil Science, Agronomy, Fish and Wildlife Administration, Fish Biology, Wildlife Refuge Management, Wildlife Biology, or Animal Science. 
BUD_EMP= sum of professional budget and account employees. Includes individuals in positions labeled as: Accounting, Auditing, or Internal Revenue Agent.

MED_EMP= sum of professional medical, hospital, dental and public health employees. Includes individuals in positions labeled as: General Health Science, Medical Officer, Nurse Anesthetist, Nurse, Dietitian and Nutritionist, Occupational Therapist, Physical Therapist, Kinesiotherapy, Manual Arts Therapist, Recreation/Creative Arts Therapist, Educational Therapist, Medical Technologist, Pharmacist, Optometrist, Speech Pathology and Audiology, Podiatrist, Dental Officer, or Industrial Hygiene.

ENG_EMP = sum of professional architecture and engineering employees. Includes individuals in positions labeled as: General Engineering, Safety Engineering, Fire Protection Engineering, Materials Engineering, Landscape Architecture, Architecture, Civil Engineering, Environmental Engineering, Mechanical Engineering, Nuclear Engineering, Electrical Engineering, Computer Engineering, Bioengineering and Biomedical Engineering, Aerospace Engineering, Naval Architecture, Mining Engineering, Petroleum Engineering, Agricultural Engineering, Chemical Engineering, or Industrial Engineering.

LEGAL_EMP= sum of legal and kindred employees. Includes individuals in positions labeled as: Law Clerk, General Attorney, or Administrative Law Judge. PHYSCI_EMP $=$ sum of professional physical science employees. Includes individuals in positions labeled as: General Physical Science, Health Physics, Physics, Geophysics, Hydrology, Chemistry, Metallurgy, Astronomy and Space Science, Meteorology, Geology, Oceanography, Cartography, Geodesy, Land Surveying, Forest Products Technology, Food Technology, Textile Technology, or Photographic Technology. 
MATH_EMP= sum of mathematics and statistical employees. Includes individuals in positions labeled as: General Mathematics and Statistics, Actuarial Science, Operations Research, Mathematics, Mathematical Statistics, or Statistics.

APPT_EXECUTIVE = sum of executive appointees to agency. This is the sum of employees that are excepted from civil service laws and implanted on a nonpermanent basis.

APPT_SCHEDC $=$ sum of schedule $\mathrm{C}$ appointees to agency.

\section{AGENCY IDEOLOGY MEASURES:}

CARSUPPORT $=$ sum of employees who either 'Strongly Agree' or 'Agree' with the following survey question in Federal Employee Viewpoint Survey: "How satisfied are you with the policies and practices of your senior leaders?". The survey question of asked in 2004, 2006, 2008, 2010, 2011. To establish data points for the missing data points, I average the results of the prior and post survey results. For the year 2003, I repeat the data point from 2004. Survey results accessed at: www.fedview.opm.gov.

CL_IDEO=1 agency leans conservative, 0 agency is neither consistently liberal nor conservative, and -1 if the agency leans liberal. The agency ideology measure based on expert survey by Joshua Clinton and David Lewis. They sent the survey with 37 experts in bureaucratic politics including academics, journalists and think tanks and 23 responded (62 percent response rate). (They had a 62\% response rate.) See Clinton and Lewis's 2008 article "Expert Opinion, Agency Characteristics, and Agency Preferences," 
Political Analysis 16(1): 3-16. The dataset includes measures of 82 agencies. The data can accessed at: https://my.vanderbilt.edu/davidlewis/data/.

CADIFF $=$ difference between career managers in and appointee ideology in bureaucratic agencies. The measure was developed by Joshua Clinton, Anthony Bertelli, Christian Grose, David Lewis, and David Nixon They surveyed 7.448 administrators and program managers (both appointed and career) about 14 policy issues voted on by Congress in 2006. The response rate was 33\%, but lower at the higher level appointees. 59\% of respondents were Democrats, which is a reasonable correspondence to the likely partisan composition of the federal bureaucracy. The ideology estimates for administrative agencies were developed through a survey in 2007 and 2008, but they use the survey to make inferences on those in 2005 and 2006. See Clinton, et al. 2012. "Separated Powers in the United States: The Ideology of Agencies, Presidents, and Congress.” American Journal of Political Science 56(2): 341-54. The dataset is available electronically at http://agencydata.wordpress.com. 


\section{Appendix B. Null Results and Alternative Model Specifications}

\section{TABle 1. Estimating THE INTERACTIVE EFFECTS ON ADVISORY COMMITTEe ReneWAL: AgenCy Ideology( EXPert SurVey) X Professional TeChNiCAL EMPLOYEeS}

\begin{tabular}{|l|c|c|}
\hline Interactive Effects & Model 3. & Model 4. \\
\hline Effect of Technicality for Most Liberal & .961 & .754 \\
Agency (Minimum) & $(1.403)$ & $(1.085)$ \\
\hline Effect of Technicality for I Standard & .274 & .173 \\
Deviation below mean Agency Ideology & $(.782)$ & $(.606)$ \\
\hline Effect of Technicality for Mean Agency & -.426 & -.420 \\
Ideology & $(.318)$ & $(.266)$ \\
\hline Effect of Technicality for I Standard & $-1.126^{*}$ & $-1.013^{*}$ \\
Deviation above mean Agency Ideology & $(.689)$ & $(.558)$ \\
\hline Effect of Technicality for Most Conservative & -1.976 & -1.734 \\
Agency (Maximum) & $(1.454)$ & $(1.150)$ \\
\hline
\end{tabular}

Effects are calculated from Model 3 and Model 4 in Table 8 in the paper.

\section{TABLe 2. EsTimATING THE INTERACTIVE EFFECTS ON ADVISORY COMMITTEE RENEWAL: CAREER SUPPORT (FEVS) X PROFESSIONAL TECHNICAL EMPLOYEES}

\begin{tabular}{|l|c|}
\hline \multicolumn{1}{|c|}{ Interactive Effects } & Model 7. \\
\hline $\begin{array}{l}\text { Effect of Technicality for Minimum Level of Career } \\
\text { Bureaucrat Support/ }\end{array}$ & .218 \\
\hline $\begin{array}{l}\text { Effect of Technicality for 1 Standard Deviation below mean } \\
\text { Level of Career Bureaucrat Support }\end{array}$ & -.232 \\
\hline $\begin{array}{l}\text { Effect of Technicality for Mean Level of Career Bureaucrat } \\
\text { Support }\end{array}$ & $(.405)$ \\
\hline $\begin{array}{l}\text { Effect of Technicality for 1 Standard Deviation above Mean } \\
\text { Level of Career Bureaucrat Support }\end{array}$ & -.575 \\
\hline $\begin{array}{l}\text { Effect of Technicality for Maximum Level of Career } \\
\text { Bureaucrat Support }\end{array}$ & -.916 \\
\hline
\end{tabular}

Effects are calculated from Model 7 in Table 8 in the paper. 
Table 3. Advisory Committee Creation: Alternative Specification

\begin{tabular}{|c|c|c|c|c|c|c|c|c|}
\hline Variable & $\begin{array}{l}\text { Model 1. } \\
\text { 2001-2008 }\end{array}$ & $\begin{array}{l}\text { Model 2. } \\
2001-2008\end{array}$ & $\begin{array}{l}\text { Model 3. } \\
\text { 2001-2011 } \\
\end{array}$ & $\begin{array}{l}\text { Model 4. } \\
\text { 2001-2011 }\end{array}$ & $\begin{array}{l}\text { Model 5. } \\
\text { 2002-2011 }\end{array}$ & $\begin{array}{l}\text { Model 6. } \\
2002-2011 \\
\end{array}$ & $\begin{array}{l}\text { Model } 7 . \\
\text { 2001-2008 }\end{array}$ & $\begin{array}{l}\text { Model 8. } \\
\text { 2001-2008 } \\
\end{array}$ \\
\hline $\begin{array}{l}\text { Professional \& } \\
\text { Technical } \\
\text { Employees (\%) } \\
\text { Agency Ideology } \\
\text { Expert Survey (CL) } \\
\text { Prof. \& Tech } \\
\text { Employees } x \text { Agency } \\
\text { Ideology (CL) } \\
\text { Career Support } \\
\text { (FEVS) } \\
\text { Prof. \& Tech. } \\
\text { Employees } x \text { Career } \\
\text { Support } \\
\text { Career-Appointee } \\
\text { Difference } \\
\text { Prof. \& Tech } \\
\text { Employees } x \\
\text { Career-Appointee } \\
\text { Difference } \\
\text { Bush } \\
\text { Sum of Employees } \\
\text { (Log) } \\
\text { Divided } \\
\text { Government } \\
\text { Commission } \\
\text { Transition Years } \\
\text { Existing Technical } \\
\text { Committees } \\
\text { Constant }\end{array}$ & $\begin{array}{c}.372 * * \\
(.167) \\
-.435 \\
(.268) \\
-.298 \\
(.703) \\
.017 \\
(.435) \\
.027 * * * \\
(.009) \\
-6.490 \\
(1.623)\end{array}$ & $\begin{array}{c}.320 * * \\
(.135) \\
-.434 * \\
(.268) \\
-.248 \\
(.721) \\
-.018 \\
(.435) \\
.025 * * \\
(.011) \\
-6.581 \\
(1.659)\end{array}$ & $\begin{array}{c}.647 * * \\
(.291) \\
.409 * * * \\
(.155) \\
-.373 \\
(.223) \\
.001 \\
(.682) \\
-.118 \\
(.322) \\
.025 * * * \\
(.008) \\
-7.557 \\
(1.732)\end{array}$ & $\begin{array}{c}.652 * * \\
(.291) \\
.484 * * * \\
(.171) \\
-.373 * \\
(.222) \\
.055 \\
(.694) \\
-.117 \\
(322) \\
.022 * \\
(.012) \\
-7.660 \\
(1.752)\end{array}$ & $\begin{array}{c}.626 * \\
(.347) \\
.353^{* * *} \\
(.144) \\
-.212 \\
(.264) \\
-.004 \\
(.646) \\
-.179 \\
(.541) \\
.026 * * * \\
(.006) \\
-6.159 \\
(1.882)\end{array}$ & $\begin{array}{c}.642 * * \\
(.298) \\
.361 * * * \\
(.147) \\
-.105 \\
(.268) \\
.097 \\
(.677) \\
-.352 \\
(.335) \\
.027 * * * \\
(.006) \\
-7.651 \\
(4.031)\end{array}$ & $\begin{array}{c}.022 \\
(.163) \\
-.387 \\
(.328) \\
-1.827 \\
(.918) \\
-.147 \\
(.403) \\
.027 * * * \\
(.004) \\
-2.321 \\
(1.816)\end{array}$ & $\begin{array}{c}\text { No } \\
\text { Solution }\end{array}$ \\
\hline
\end{tabular}

$*$ Variable is significant at the .10 level $* *$ Variable is significant at the .05 level

$* * *$ Variable is significant at the .01 level 


\section{TABLE 4. ESTIMATING THE INTERACTIVE EFFECTS ON AdVISORY COMMITTEE CREATION: AgENCY IDEOLOGY ( EXPERT SURVEY) X PROFESSIONAL TECHNICAL EMPLOYEES}

\begin{tabular}{|l|c|c|}
\hline \multicolumn{1}{|c|}{ Interactive Effects } & $\begin{array}{c}\text { Model 2. } \\
\mathbf{2 0 0 1 - 2 0 0 8}\end{array}$ & $\begin{array}{c}\text { Model 4. } \\
\mathbf{2 0 0 0 - 2 0 1 1}\end{array}$ \\
\hline Effect of Technicality for Most Liberal & $\begin{array}{c}5.992 \\
(4.029)\end{array}$ & 5.692 \\
Agency (Minimum) & $5.450^{* *}$ & $5.030^{* *}$ \\
\hline Effect of Technicality for 1 Standard & $(2.425)$ & $(2.248)$ \\
Deviation below mean Agency Ideology & $4.897^{* * *}$ & $4.354^{* * *}$ \\
\hline Effect of Technicality for Mean Agency & $(1.286)$ & $(1.223)$ \\
Ideology & & \\
Effect of Technicality for 1 Standard & $4.344^{* *}$ & $3.679 * *$ \\
Deviation above mean Agency Ideology & $(1.959)$ & $(1.854)$ \\
\hline Effect of Technicality for Most Conservative & 3.673 & 2.859 \\
Agency (Maximum) & $(3.885)$ & $(3.629)$ \\
\hline
\end{tabular}

\section{TABLE 5. ESTIMATING THE INTERACTIVE EFFECTS ON AdVISORY COMMITTEE CREATION: CAREER Support (FEVS) X Professional TeChNiCAL EMPLOYEeS}

\begin{tabular}{|l|c|}
\hline \multicolumn{1}{|c|}{ Interactive Effects } & Model 6. \\
\hline & \\
Effect of Technicality for Minimum Level of & 4.357 \\
Career Bureaucrat Support & $(2.752)$ \\
\hline Effect of Technicality for 1 Standard & $3.693 * *$ \\
Deviation below mean Level of Career & $(1.455)$ \\
Bureaucrat Support & $3.190^{* * *}$ \\
\hline & $(1.048)$ \\
Effect of Technicality for Mean Level of & 2.687 \\
Career Bureaucrat Support & $(1.660)$ \\
\hline Effect of Technicality for 1 Standard & \\
Deviation above Mean Level of Career & 1.314 \\
Bureaucrat Support & $(4.573)$ \\
\hline Effect of Technicality for Maximum Level of & \\
Career Bureaucrat Support &
\end{tabular}




\title{
LAYERING EXPERTS: AdVISORY COMMITTEES, INFORMATION, AND POLICYMAKING
}

\begin{abstract}
Following the delegation of authority from Congress to the bureaucracy, agency secretaries, like other political actors, adopt strategies to further their institutional goals and to shape agency policy in line with their preferences. In this paper, I investigate one common institutional tool-advisory committees — employed by agency secretaries. Although it has been proposed that advisory committees are essentially tools of blame avoidance that provide no new information to bureaucrats, this paper argues that agency secretaries establish technical advisory committees to lower the costs of expertise acquisition for career bureaucrats. Therefore, advisory committees comprised of external experts supply policy-relevant information to the agency, and their recommendations affect agency decisions. Through statistical analysis on an original dataset of pharmaceutical drug approval decisions in the Food and Drug Administration (20012008), the paper concludes that advisory committees do provide the agency with policy-relevant information, and that their recommendations substantially affect the FDA's decision to approve a pharmaceutical drug for the market.
\end{abstract}


In contemporary political life, executive agencies are responsible for seeking out information and developing regulations on complicated policy issues, including preparing public health responses to avian flu, protecting our water sources from contamination, deciding if new forms of oil and gas excavation pose a danger to the health and safety of nearby residents, and assessing whether a new drug is safe for distribution. Regulation in these policy areas requires that agencies amass considerable information and expertise if they are to minimize uncertainty about the relationship between a policy and its consequences. Although there are many possible strategies to cope with information problems, one common strategy is the use of expert advisory committees. Through advisory committees, agencies assemble experts from the private sector and research universities to provide information on a new issue or review the policy assessments of career bureaucrats. These committees regularly advise the Environmental Protection Agency, the Food and Drug Administration, the Centers for Disease Control, and many others. Their presence across the federal bureaucracy raises questions about why agencies construct advisory technical committees and to what effect. Despite their prevalence, our knowledge about these committees and their effects on policy is relatively limited (Lavertu, Walters, and Weimer 2012; Lavertu and Weimer 2011; Moffitt 2010; Balla and Wright 2001; Jasanoff 1992; Smith 1990). In "Generating Expertise or Exerting Political Control," I argue that advisory committees are institutional mechanisms for lowering the cost of expertise acquisition. The paper contends that when facing a higher degree of policy uncertainty, agency secretaries establish committees to both subsidize and incentivize expertise acquisition. The paper then provides evidence that agency leaders are more likely to establish expert committees as the technicality of agency policymaking increases. These findings raise questions about whether advisory committees, once established in technical agencies, affect policy decisions. Their affect on policy outcomes 
has important implications for understanding the role of advisory committees in bureaucratic policymaking, and more broadly, how technical agencies cope with policy uncertainty.

If agency leaders create committees as an institutional mechanism for improving expertise acquisition, then I expect that their recommendations will affect policy outcomes. Why create committees to provide information, but then ignore their recommendations? However, alternative explanations are also possible. The heads of technical agencies could have a different reason other than information for incorporating these committees into the policy process. Moffitt (2010) argues the FDA seeks public advice from expert committees in order to signal to agency watchers that there is a high degree of uncertainty surrounding a particular policy decision. On this view, the committees do not provide novel information that can then be incorporated into policy choices or incentivize research effort, but only serve to communicate uncertainty over complex and difficult choices. In the event of policy failure, this public discussion of the policy choice could serve to disperse blame.

The following will first describe advisory committees in greater detail and then lay out the argument for committees as information gathering mechanisms. The empirical section of the paper will test these claims by estimating the effect of advisory committee recommendations on pharmaceutical drug approval decisions in the FDA. In order to test these claims, I built an original dataset of drug approval decisions between 2001 and 2008. The evidence indicates that recommendations of expert committees have a strong effect on policy outcomes.

\section{What ARE AdVisory COMmitTees?}

As noted, advisory committees are a common feature of bureaucratic policymaking. In 2010, there were 1,046 advisory committees of which 1,007 advised agencies, 39 advised 
presidents directly, and 0 advised Congress. Agency leaders have created 446 of these committees across 77 agencies to advise bureaucratic decision-making (Calculated from the Federal Advisory Committee Database).$^{32}$ Once constructed, they provide an institutional forum within the policymaking process for consultation with affected business and private sector interests as well as external experts. They are primarily composed of individuals drawn from the private sector rather than members of the executive's permanent staff, civil servants, or elected officials. ${ }^{33}$ Through these committees, members of Congress, presidents, and agency secretaries embed stakeholder interests, representatives from advocacy organizations and professional societies, or external experts from academia, research institutions, and the private sector into the policymaking process. $^{34}$

Advisory committees only provide the agency with information. Their policy recommendations do not hold the weight of law. "Determination of action" on their recommendations must be made through the typical policymaking channels (the legislative process, the rulemaking process, or presidential directive) "unless otherwise specified" by Congress or the president (U.S. Public Law 92-463). With some exceptions, the advice they provide is public. $^{35}$

\footnotetext{
32 The General Services Administration calculated that, in 2010, 69,118 individuals served on these committees at a cost of $\$ 395.2$ million and 1,464 regular government employees worked as liaisons between the agency and committee or as support staff ("Spending on Advisory Committees" and "What is the Composition of Advisory Committees").

${ }^{33}$ The law governing advisory committees is the Federal Advisory Committee Act of 1972 (U.S. Public Law 92-463).

${ }^{34}$ The term length of advisory committee members and whether the terms are fixed or staggered vary so agency leaders may not be able to appoint every member of an existing advisory committee, but they will be able to appoint a significant number of the slots. Terms are typically 2-4 years.

${ }^{35}$ Except for committees advising agencies on classified matters, committee documents are subject to the Freedom of Information Act (U.S. Public Law 92-463).
} 
Agencies codify committees into one of five main categories based on the committee's composition and purpose: 1) grant-making committees, 2) policy issue committees, 3) program committees, 4) negotiated rulemaking committees and 5) scientific technical committees. ${ }^{36}$ The following analysis focuses on scientific technical experts, which are functionally committees of external experts. The membership of these committees primarily consists of non-stakeholder experts drawn from academia, research institutions, and other areas of the private sector.

Stakeholders are sometimes given non-voting representation on technical committees. ${ }^{37}$ This paper focuses on the subset of advisory committees established by agencies and staffed with technical experts.

\section{The Argument}

Following appointment, agency secretaries assume their temporary post at the helm of a large organization. From this position, they have the authority to adopt strategies within the organization to increase the probability that they will achieve their preferred policy outcomes. They need to consider both how to compel agents to acquire the information necessary to make policy decisions and to use that information in a way that aligns with their preferences (Gailmard and Patty 2007, 2012; Stephenson 2008, 2011). ${ }^{38}$

\footnotetext{
${ }^{36}$ There are also some committees labeled as Special Emphasis Panels. These are mainly in the National Institute of Health (NIH). These panels function similarly to grant-making committees, but some both review grants and give technical recommendations on NIH programs. The main characteristics of each committee can be found in the General Services Administration's Federal Advisory Committee database from 1999 to the present.

${ }^{37}$ For example, in the pharmaceutical drug review committees in the FDA, the pharmaceutical industry is given non-voting representation.

38 There is an extensive literature the principal agent problem faced by political actors. This literature emphasizes that there is an inherent and unavoidable loss to the principal's welfare in delegation due to the problems of moral hazard and adverse selection, but that delegation is advisable when the benefits of efficiency and expertise outweigh the losses (McCubbins and
} 
Compelling bureaucrats to develop and maintain expertise is difficult, because, as Stephenson (2011) summarizes, an "agents' private incentive to invest in research may not align with the social interest in their doing so." (Stephenson, 1426; see also Gailmard and Patty 2012, 6) Furthermore, agency leaders need to compel bureaucrats to invest in expertise within the constraints of the civil service where a system of financial rewards and punishments is unavailable. ${ }^{39}$ In order to stimulate expertise acquisition, agency leaders can manipulate the private costs or benefits of research effort. Typically, research on incentizing expertise has focused on the ways that political actors can increase the private benefits of research effort by granting bureaucrats policy discretion (Gailmard and Patty 2007, 2012; Epstein and O'Halloran 1999; Bawn 1995). Others have emphasized the ways that principals can impose enactment costs on bureaucrats seeking policy rewards (Stephenson 2007, 2008, 2012). For example, political principals can raise the costs associated with adopting a policy option thereby forcing bureaucrats to invest in research in order to realize a policy goal (Stephenson 2007, 2011; Gailmard 2009). In both cases, principals affect research effort by dangling the possibility of policy rewards.

When policy is complex and requires highly skilled labor, policy uncertainty is likely to be high and the challenge of developing agency expertise even greater. Leaders of technical agencies, like the FDA, struggle to recruit and retain highly skilled personnel. Individuals with

Kiewiet 1991). On this account, political actors adopt strategies to limit those losses or the ability of bureaucrats to move policy away from what political principals prefer (McCubbins and Schwartz 1984; McCubbins, Noll and Weingast 1987, 1989; Epstein and O’Halloran 1999; Lewis 2003, 2010).

${ }^{39}$ Even if a system of financial rewards and punishments were available, principals still face the problem of hidden information. It is difficult to determine whether the agents has engaged in sufficient information-gathering or effort, because the principal cannot easily observe effort or assess the quality of a policy decision, particularly the often complicated, long term consequences of a given policy. 
highly skilled labor, like those needed for pharmaceutical drug or clean air regulation, possess career opportunities outside government that can offer greater remuneration and prestige. An individual with a medical degree and a Ph.D. may prefer to work in an academic research institution developing new therapies rather than assessing the work done by others from a position in government. Alternatively, they may prefer the financial rewards of working for a drug firm.

In addition, once skilled bureaucrats are hired, it is difficult to compel them to update their expertise in response to technological advances. Policy rewards may be insufficient to motivate expertise acquisition if the costs of acquiring that expertise are significant. Even if we assume that bureaucrats in such areas care deeply about making the right policy choice and wish to avoid approving a harmful chemical or drug, the costs of developing the necessary expertise for each decision is quite high. For example, in order to assess the sufficiency of the evidence presented by pharmaceutical drug companies in their applications for approval, a career bureaucrat reviewing drug applications in the FDA must stay abreast of new research methods, possess expertise on a range of different diseases, and be aware of the ways in which drugs may have harmful effects on certain subpopulations.

Advisory committees provide a venue in which agencies can ask a select group of experts for information on a new policy issues or for their assessment of a proposed policy choice. Because committee members retain their posts in academic institutions, research organizations or firms, the agency can recruit individuals to serve on committees that that would be unable to hire 
on a permanent basis. As a result, the agency can solicit information from individuals at the top of their fields with minimal financial cost. ${ }^{40}$

Agency secretaries can use these committees to alter the private costs of expertise acquisition in two ways. First, when agencies face a new policy issue, secretaries can subsidize the cost of research by establishing a committee. So rather than toiling on their own by reading through new research and reaching out to experts independently, advisory committees build into the decision-making process (and a career bureaucrat's regular work day) the acquisition of information on specific policy questions that the bureaucrat is trying to solve. Expert advisory committees institutionalize the process of reaching out to individuals with expertise in the relevant area.

Second, committees can incentivize research effort by directly reviewing the technical evidence bureaucrats have assembled in support of a policy decision. In these cases, career bureaucrats research the policy question, present their findings, and pose specific questions to experts. If a bureaucrat is policy-motivated, public review of their policy assessments by a panel of respected external experts could motivate research effort because it could reveal inadequate research effort damaging that individual's reputation for competence and potentially their employment prospects both inside and outside of the agency. For example, the FDA often requests an advisory committee to review the agency and the firm's arguments for approval. The review can also potentially catch errors in the bureaucrat's assessment.

\footnotetext{
${ }^{40}$ In support of this point, Volden (2002) has found that states have turned to policy advisory boards when state financial resources are fewer and governments less professional. On costs, the total cost of running the advisory committee system in 2011 was $\$ 395.2$ million and the system consists of 70, 605 individuals so the per person cost of the system is $\$ 5,597.33$. Of the 70,605 advisory committee members, 1,464 are regular government employees that serve as liaisons between the agency and the committees. So the actual cost per advisory committee member is actually lower (U.S. General Services Administration, "What is the Composition of Committees"; U.S. General Services Administration, "Spending on Advisory Committees").
} 
If agency secretaries require consultation with committees to lower the costs of information acquisition and improve the agency's ability to reduce policy uncertainty, then their recommendations should provide meaningful information to be incorporated into policy decisions. Visible disagreement with and disregard of a panel of experts could cause political actors or interest groups to question agency decisions and open the agency to criticism. As a result, agencies should only seek external expertise when there is substantive informational value to the recommendations. Therefore, I expect that committee recommendations will affect agency decisions even when the agency's prior position is taken into account.

An alternative position to the one proposed here is that when policy failure is probable, agencies create committees to diffuse blame. Moffitt argues that the FDA uses advisory committees (1) to signal uncertainty about their policy choice to those outside the agency and (2) to highlight the FDA's reliance on information provided by the pharmaceutical companies. She argues that bureaucrats care deeply about the agency's reputation, and as a result, they turn to advisory committees to increase the "publicity and public participation for tasks that risk implementation failure.” (Moffitt, 880) On this view, the agency can minimize blame in the event of a policy failure by publicly highlighting the complexity of the policy decision and the responsibility of other actors in matter. Here advisory committees are not used to develop expertise or introduce policy-relevant information. She contends that if agencies wanted to seek information, they would do so privately.

There are several reasons to question Moffitt's conclusions. In her analysis, she presents evidence that bureaucrats consult with committees when uncertainty about the correct policy choice is likely to be high (Moffitt 2010, 882, 885-886). She dismisses the claim that the FDA creates advisory committees to augment capacity, because they do not refer new drug 
applications to advisory committees more frequently following an organizational restructuring (Moffitt 2010, 882, 885-886). Her analysis does not directly test the effect of advisory committee recommendations on policy outcomes.

Her argument raises the question of why agencies consult with external experts publicly rather than privately. First, if secretaries want to institutionalize the review of agency decisions through committees, they are forced to do so publicly. Prior to the Federal Advisory Committee Act of 1972, the deliberations and reports of advisory committees were private. The new legislation, however, required that documents produced by committees be subject to the Freedom of Information Act. As a result, agencies face a trade-off between consistent, institutionalized support for career bureaucrats that is public and relying on consultation with individuals that is private.

Agencies can and do also contract with experts privately. Unlike advisory committees, the work of consultants is even exempt from Freedom of Information Act requests. However, if agencies seek information, there are some benefits to doing so publicly. The public nature of advice could propel these private sector experts and agency bureaucrats to engage in greater research effort on the policy question at hand prior to making a recommendation. If a private sector expert's advice becomes associated with policy a failure, they could pay a reputational cost in their professional lives outside of government. If their advice becomes associated with a policy failure, they could pay a reputational cost. For example, a medical researcher who recommends approval of a drug that turns out to have serious unanticipated harmful effects will likely incur such costs. 
Furthermore, it is unlikely that agencies would expose themselves to public criticism by credible critics unless the information is useful. It is unclear how the consulting an advisory committee would diffuse blame if, when uncertainty is high, the agency chooses to adopt a policy opposed by a committee of external experts. There are prominent examples of the agency making a policy choice that contradicts the committees. Recently, the agency decided two approve two drugs that its reviewing committee recommended be rejected (Pollack 2013). It is unclear how it would help the agency diffuse blame in the future when they acted in opposition to a group of respected experts.

\section{THE EMPIRICAL TEST}

In the following analysis, I will test the following hypotheses on an original dataset of drug approval decisions.

H1. Information Hypothesis: Advisory committees are created to lower the costs of expertise acquisition. Therefore, their recommendations provide bureaucrats with meaningful policy-relevant information that will affect agency policy choices.

H2. Signaling Hypothesis: Advisory committees are created to disperse blame in the event of policy failure by highlighting the agency's reliance on information provided by pharmaceutical companies. They signal uncertainty about a policy choice, but their recommendations will not affect policy outcomes.

In order to test the claim that advisory committees affect policy outcomes, one would need the following pieces of information: (1) an estimate of the agency's position on a policy proposal prior to advisory committee consultation, (2) a quantitative measure-like a vote—of advisory committee support for a policy, (3) estimates of other important factors affecting the agency's decision to adopt the policy, and (4) information about whether the policy was 
subsequently adopted. ${ }^{41}$ In addition to being a substantively important policy area, the pharmaceutical drug approval process fits preceding requirements. At most advisory committee meetings convened to assess a new drug application, career bureaucrats reveal their assessment of the application prior to a committee vote. ${ }^{42}$ Having this information allows me to discern the effect of the committee vote as distinct from the agency's pre-existing preferences. In addition, pharmaceutical drug regulation is a consequential policy area that touches the lives of most citizens across the country in some way, and the findings can contribute to a growing literature on policymaking in the FDA (Carpenter, Chattopadhyay, Moffitt and Nall 2012; Lavertu and Weimer 2011; Carpenter 2002, 2004, 2010; Moffitt 2010; Olson, 1999). The findings of this analysis should be generalizable across technical agencies that consult with expert advisory committees.

Note that the use of expert advisory committees by agency secretaries is not evenly distributed across all policy areas. Instead, such committees are concentrated in those areas where agencies must engage in technical, often scientific, analysis, such as the FDA, the National Institute of Health (NIH), the Center for Disease Control (CDC), the Federal Aviation Administration (FAA), the Environmental Protection Agency (EPA), and National Aeronautics and Space Administration (NASA). ${ }^{43}$

\footnotetext{
${ }^{41}$ The ideal way to test whether committees affect outcomes would be in an experimental setting, but given the context of observational data, these criteria will improve estimates of their effect.

${ }^{42}$ Lavertu and Weimer (2011) also test the effect of advisory committee vote on the decision to approve a drug. However, they do not include any measure of agency's preferences for approval in their model.

${ }^{43}$ Quantitative evidence for this claim can be found in "Generating Expertise or Exerting Political Control." Agency secretaries also generate committees of stakeholder interests, and these committees are often concentrated in other policy areas, but as previously stated, understanding when and why agency leaders build these types of committees and to what effect will not be addressed in this paper.
} 


\section{DATA AND EMPIRICS}

To test the claim that advisory committees have an informational effect on agency decision-making, I built a dataset of FDA drug approval decisions during the George W. Bush administration (2001-2008). ${ }^{44}$ First, I will briefly introduce the drug review process and discuss the contents of the dataset. Then I will estimate a model of the drug approval process. Specifically, the model will estimate the extent to which advisory committee votes affect FDA drug approval decisions. Finally, the paper concludes by calculating the substantive effects of changes in advisory committee support on the predicted probability of approval.

Prior to marketing a new drug or expanding the use of an already marketed drug to new populations, pharmaceutical companies are required to submit a New Drug Application (NDA) to the FDA. ${ }^{45}$ For a drug to be approved, the application must demonstrate that the drug is both safe and effective in treating the proposed disease or condition (U.S. Public Law 87-781). The sponsor must present evidence in the form of two well-controlled clinical trials, and the FDA bases its approval decision primarily on the results of the two trials (U.S. Public Law 87-781).

For a substantial subset of NDA's, the FDA requests that an advisory committee of experts, mainly academic medical researchers and practicing doctors, review the application and vote on approval. ${ }^{46}$ Agency leaders within the FDA—not the president or members of

\footnotetext{
${ }^{44}$ Complete transcripts of advisory committee meetings are available from 1999-2011 on the FDA's website.

${ }^{45}$ Pharmaceutical companies must go through the New Drug Application (NDA) process if they want to 1) introduce a new drug or new molecular entity (NME) onto the market, 2) expand the diseases or conditions (indication) that an already marketed drug is approved to treat, 3) expand the target population for the drug or 4) obtain over-the-counter status for a prescription drug. All of these types of applications are included in the dataset in addition to cases where the committee votes on whether to withdraw an already approved drug from the market.

46 The decision to send a NDA to an advisory committee seems to be based upon uncertainty about the evidence for approval or in some cases, controversy over the application. In discussion, FDA officials typically emphasize that they are calling together the advisory committee due to
} 
Congress-established all advisory committees that currently review NDAs. If the agency requests that an advisory committee review an NDA, the FDA distributes the application to members of the advisory committee, including all the details of the clinical trials, and a meeting date is announced in the Federal Register. At the meeting, the firm presents their case for approval to the committee, and then the FDA medical reviewers present their analysis of the application. They typically discuss concerns they have about aspects of the clinical trials, especially where their own analysis on the drug's safety and efficacy conflicts with the conclusions of the firm applying for approval. The bureaucrats' presentation indicates whether they find the drug in question to be safe and effective, of questionable safety and efficacy, or not safe or effective. At each meeting, interest groups and members of the public have an opportunity to present their views. Finally, the committee publicly votes on approval of the application. Due to transparency provisions in the Federal Advisory Committee Act of 1972, advisory committees are required to make meeting documents publicly available. Agencies vary in the records they keep of these meetings - some keep transcripts, some minutes, and some only make available formal reports of the committee's conclusions. However, the FDA provides transcripts, which allows me to code the preferences of the FDA medical reviewers, advisory committee members and interest groups.

My dataset includes every NDA voted on by an advisory committee from 2001-2008 (See Appendix A for details on coding). The dataset consists of 162 observations (NDA applications) that were reviewed by 16 different standing advisory committees within the Center for Drug Evaluation and Research (CDER). In addition, it is important to note that advisory committee recommendations and the FDA's preliminary evaluation are not equivalent and that

questions with the application. Moffitt (2010) finds that priority review is a predictor of sending the drug to an advisory committee. 
there are frequent observations where the two groups are in conflict over approval. The FDA evaluation variable and the advisory committee vote have a correlation coefficient of .50 . Variable descriptions and summary statistics of the dependent variable and explanatory variables appear below in Table 1.

I will estimate the effect of Advisory Committee Vote, in addition to a range of control variables, on the probability of drug approval using a probit model. The dependent variable is a dichotomous variable indicating whether a drug application was approved (FDA Approval). In my sample, the FDA approved 67.0 percent of the new drug applications with a standard deviation of 47. The mean Advisory Committee Vote was 70.0 percent in favor of approval with a standard deviation of 34.1 percent. The variable capturing the FDA's preliminary evaluation of the drug application had the potential to range from 0 to 4 with a possible score of 0 to 2 for safety and a possible score of 0 to 2 for efficacy (FDA Evaluation). A score of four indicated that the FDA found the drug to be both safe and efficacious. The mean FDA Evaluation was 2.9 with a standard deviation of .95 , which indicates that for most applications that were considered by advisory committees the FDA was uncertain about either the efficacy or safety of the drug.

I also include two variables to capture interest group pressure-Interest Groups ProApproval and Interest Groups Anti-Approval. Interest groups have the opportunity to present their case for approval or rejection at advisory committee hearings. So for each NDA, I counted the number of interest groups that made presentations in favor (Interest Groups Pro-Approval) or against approval (Interest Groups Anti-Approval) to serve as a proxy for interest groups active on the drug application. I also include a variable that estimates public demand for disease treatments. It is plausible that public attention to a disease or condition may increase the probability that a drug application will be approved even if the drug has some risks. The 
TAble 1. Summary OF EXPlanatory Variables And Their Predicted EFfects

\begin{tabular}{|c|c|c|c|}
\hline Variable & Description & $\begin{array}{c}\text { Mean } \\
\text { (Standard Deviation) }\end{array}$ & Expected Effect \\
\hline FDA Approval & $\begin{array}{l}\text { Dichotomous variable } \\
\text { indicating whether or not a drug } \\
\text { application was approved } \\
\text { within } 2 \text { years of advisory } \\
\text { committee evaluation }\end{array}$ & $\begin{array}{c}.67 \\
(.47)\end{array}$ & N/A \\
\hline $\begin{array}{c}\text { Advisory } \\
\text { Committee Vote }\end{array}$ & $\begin{array}{l}\text { Advisory committee vote for } \\
\text { approval in percent. Abstentions } \\
\text { were dropped in calculating } \\
\text { percent. If voted for safety and } \\
\text { efficacy separately, then } \\
\text { averaged the two votes. }\end{array}$ & $\begin{array}{c}69.95 \\
(34.07)\end{array}$ & + \\
\hline FDA Evaluation & $\begin{array}{l}\text { FDA preliminary evaluation of } \\
\text { NDA. Potentially score } 0-2 \text { for } \\
\text { safety and } 0-2 \text { for efficacy. } \\
\text { With } 2=\text { safe or effective, } 1= \\
\text { questions about safety or } \\
\text { efficacy and } 0=\text { not safe, or not } \\
\text { effective. }\end{array}$ & $\begin{array}{c}2.9 \\
(.95)\end{array}$ & + \\
\hline $\begin{array}{c}\text { Interest Groups } \\
\text { Pro-Approval }\end{array}$ & $\begin{array}{l}\text { Count of interest groups, } \\
\text { including disease advocacy } \\
\text { groups, professional or } \\
\text { consumer associations, that } \\
\text { advocate for approval in open } \\
\text { hearing portion of advisory } \\
\text { committee meeting } \\
\end{array}$ & $\begin{array}{c}.91 \\
(1.7)\end{array}$ & + \\
\hline $\begin{array}{l}\text { Interest Groups } \\
\text { Anti- Approval }\end{array}$ & $\begin{array}{l}\text { Count of interest groups, } \\
\text { including disease advocacy } \\
\text { groups, professional or } \\
\text { consumer associations, that } \\
\text { advocate for rejection in open } \\
\text { hearing portion of advisory } \\
\text { committee meeting } \\
\end{array}$ & $\begin{array}{c}.33 \\
(.98)\end{array}$ & - \\
\hline Public Attention & $\begin{array}{l}\text { Count of New York Times } \\
\text { articles about the disease or } \\
\text { condition }\end{array}$ & $\begin{array}{c}22.95 \\
(51.17) \\
\end{array}$ & + \\
\hline Public Criticism & $\begin{array}{c}\text { Dichotomous variable } \\
\text { indicating whether there was } \\
\text { negative attention to the NDA } \\
\text { in the New York Times }\end{array}$ & $\begin{array}{l}.225 \\
(.42)\end{array}$ & - \\
\hline $\begin{array}{l}\text { Post-Vioxx } \\
\text { Scandal }\end{array}$ & $\begin{array}{c}\text { Dichotomous variable } \\
\text { demarking more cautious } \\
\text { approval environment after } \\
\text { Vioxx scandal (Post-2003) }\end{array}$ & $\begin{array}{l}.71 \\
(.45)\end{array}$ & - \\
\hline
\end{tabular}


variable, Public Attention, is a proxy for public concern by examining media attention to the disease or condition. Public Attention is a count of New York Times articles on the disease or condition in the two years prior to the advisory committee meeting. Negative public attention surrounding the clinical trials of a drug could also potentially harm the probability of approval. So I also include a variable (Public Criticism) that indicates whether there was public criticism of the drug application in the media prior to the FDA's approval decision.

In addition, I hypothesize that there was a shift in the regulatory climate at the FDA within my period of study. The agency faced a torrent of criticism from both the popular press, members of Congress, and medical journals for approving drugs that were subsequently associated with serious adverse events and then failing to react quickly enough in response to those adverse events. The main scandal was due to the deaths caused by the arthritis drug Vioxx, but there were other instances of negative publicity around this time. I expect that following accusations of regulatory negligence that the FDA will become more cautious in approving drugs and that we should expect that similar NDA's will be approved at a lower rate in the post-Vioxx world. To account for this hypothesized regulatory shift, I include a dummy variable, PostVioxx, for the applications reviewed in years following the scandal.

Table 2 presents the probit results. Model 1 reflects the results from a simple model that only assesses the effect of the FDA Evaluation and Advisory Committee Vote on approval. In the second model, I include the interest group variables, Interest Groups Pro-Approval and Interest Groups Anti-Approval, and in the third model, I add variables capturing media attention, Public Attention and Public Criticism, taking the natural $\log$ of the Public Attention variable because of the positive skew in the data for this variable. Finally, in the fourth model I also include the time 
variable-Post-Vioxx. Given that each advisory committee is the source of multiple observations, I have clustered standard errors by committee in all models.

TABle 2. Determinants of FDA DRUg ApProval

\begin{tabular}{|l|cccc|}
\hline Variable & Model 1 & Model 2 & Model 3 & Model 4 \\
Advisory Committee Vote & $.025^{* *}$ & $.024^{* *}$ & $.024^{* *}$ & $.025^{* *}$ \\
& $(.004)$ & $(.004)$ & $(.004)$ & $(.005)$ \\
FDA Evaluation & .153 & $.276^{* *}$ & $.289^{*}$ & $.280^{*}$ \\
& $(.101)$ & $(.107)$ & $(.116)$ & $(.117)$ \\
Interest Groups For Approval & & .075 & .081 & .092 \\
& & $(.063)$ & $(.064)$ & $(.057)$ \\
Public Attention (log) & & $-.420^{* *}$ & $-.528^{* *}$ & $-.577^{* *}$ \\
& & $(.095)$ & $(.066)$ & $(.073)$ \\
Public Criticism & & & .034 & .018 \\
Post-Vioxx Scandal & & & $(.110)$ & $(.097)$ \\
& & & .589 & $.645 *$ \\
Wald $\chi 2$ & & & $(.283)$ & $(.304)$ \\
Pseudo R2 & & & & $-.674 * *$ \\
Percent Correctly Predicted & & & & $(.257)$ \\
$\mathbf{N}$ & & & & \\
\hline
\end{tabular}

$*$ Variable is significant at the .05 level ** Variable is significant at the .01 level + All models employ clustered standard errors on advisory committee

To re-state, if the information hypothesis (H1) is true, then we should see the advisory committee vote variable as having a positive and significant effect on the decision to approve a drug. Alternatively, if the opposing hypothesis (H2) is true, then advisory committee vote should not predict drug approval, especially once the agency's prior position has been taken into account. The coefficient on the explanatory variable of interest, Advisory Committee Vote, is highly significant, robust to different model specifications, and substantial in effect. In addition, the explanatory variables, FDA Evaluation and Interest Groups Anti Approval, were both highly significant as expected, but the variable capturing interest groups in favor of approval (Interest Groups Pro-Approval) and media attention for the disease (Public Attention) failed to reach 
significance. The model accurately predicted 83 percent of observations. The results of the key explanatory variables were robust to alternative model specification, including models with fixed effects for year and committee as well as models employing an alternative coding of the FDA evaluation variable. ${ }^{47}$

To aid in the substantive interpretation of the probit model, I next use Monte Carlo simulations. ${ }^{48}$ Simulations are useful in the interpretation of the model, because they better account for estimation uncertainty in the calculation of quantities of substantive interest (King, Tomz, and Wittenberg 2003, 348). The results from the model above produced estimates of the parameters of interest as well as the variance and covariance of those parameters - the main quantities required for simulation. Using Clarify, I draw a set of 1,000 values of the parameters from a multivariate normal distribution, and then compute the predicted values in each of the 1,000 draws (Tomz, Wittenberg and King 2003). The sampling distribution from the 1,000 draws will provide a 95 percent confidence interval around the predicted probabilities of interest.

From the simulations, I have calculated the predicted probabilities of drug approval for varying levels of Advisory Committee Vote. To calculate the predicted probabilities, I first set the FDA Evaluation at its mean, which translates to some degree of agency uncertainty on safety and efficacy of the drug application. I have chosen to set all other continuous variables at their

\footnotetext{
${ }^{47}$ I estimated three additional variations on Model 4. First, I estimated two models- one with fixed effects for year and one with fixed effects for committee. The main estimates in the model were robust to specification. Then I performed a likelihood ratio test on the models with and without fixed effects. The results of the test revealed that including fixed effects does not improve fit at the 95 percent confidence level. Therefore, I have not included those results. I also estimated a model with an alternative coding of the FDA evaluation variable. In the all models in the paper, when the FDA does not present on safety or efficacy, I assume that the FDA is supportive of approval if they do not present at the committee meeting. As a robustness check, I ran another set of models that drop all observations where the FDA does not present. The results were again robust to specification. See Appendix A for a more detailed explanation on the coding and Appendix B for results of this alternative specification.

${ }^{48}$ All predicted probabilities are calculated from Model 4.
} 
mean and dichotomous variables at their median. As Figure 1 illustrates, when advisory committee support increases, the probability of approval also increases. It is clear that committee recommendations have a profound effect on the decision to approve. However, the signal from the advisory committee for approval has to be strong for the agency to approve the drug. The predicted probability of approval exceeds .5 when the advisory committee vote is approximately 60 percent.

Figure 1. Predicted Probabilities of Drug Approval

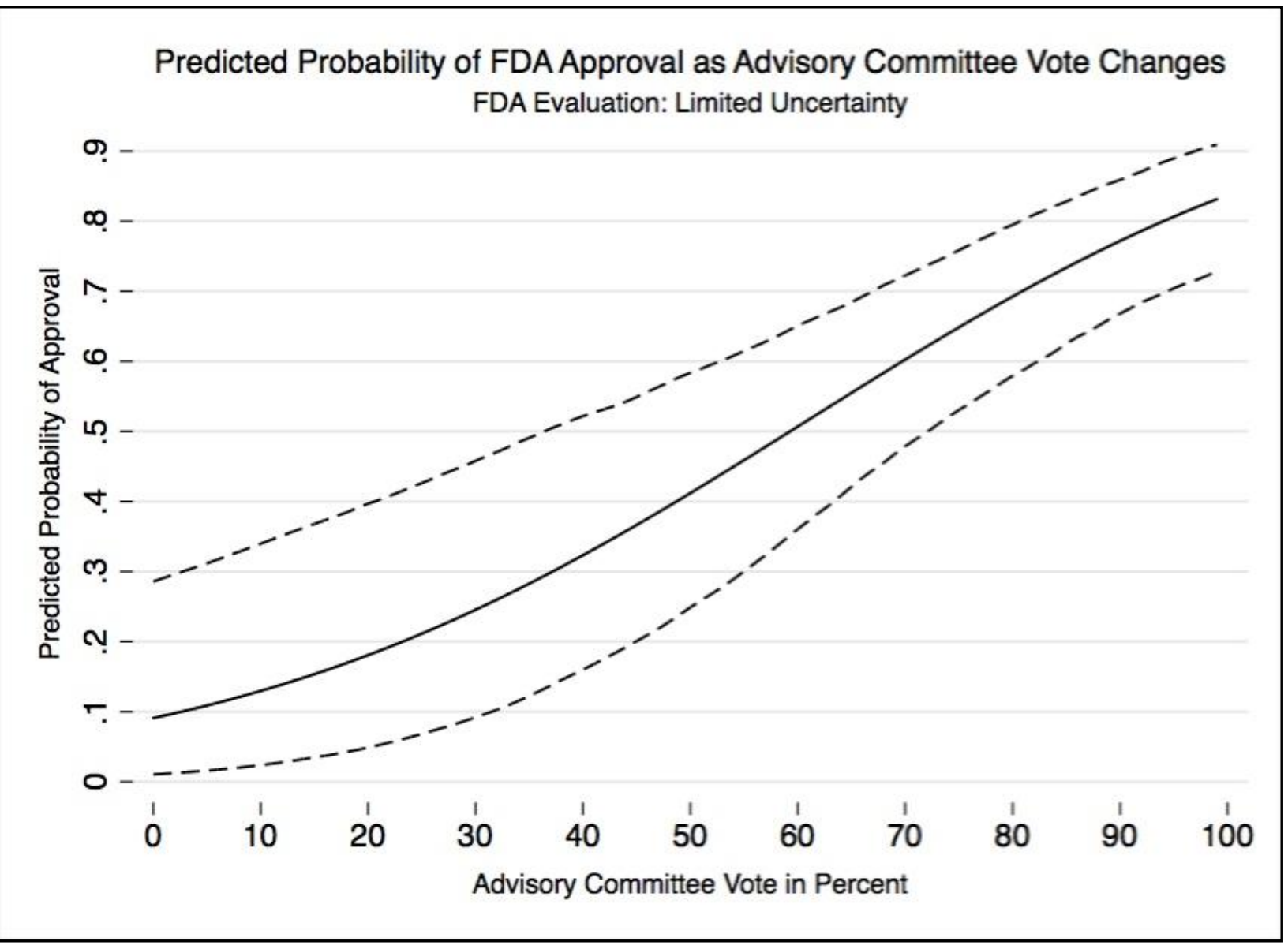

All dichotomous variables set at median, continuous variables set at mean, FDA Evaluation of Efficacy and Safety set at 3, which reflects uncertainty on either efficacy and safety. The mean of the FDA Evaluation is 2.9.

As Figure 2 illustrates, if FDA Evaluation decreases from its mean value to 2 (reflecting a higher degree of agency uncertainty), then the signal from the advisory committee needs to be stronger, 
approximately 70 percent, before the probability of approval exceeds .5. In either case, it is evident that effect of advisory committee recommendations on the probability of approval is quite large.

\section{Figure 2. Predicted Probability of Drug Approval}

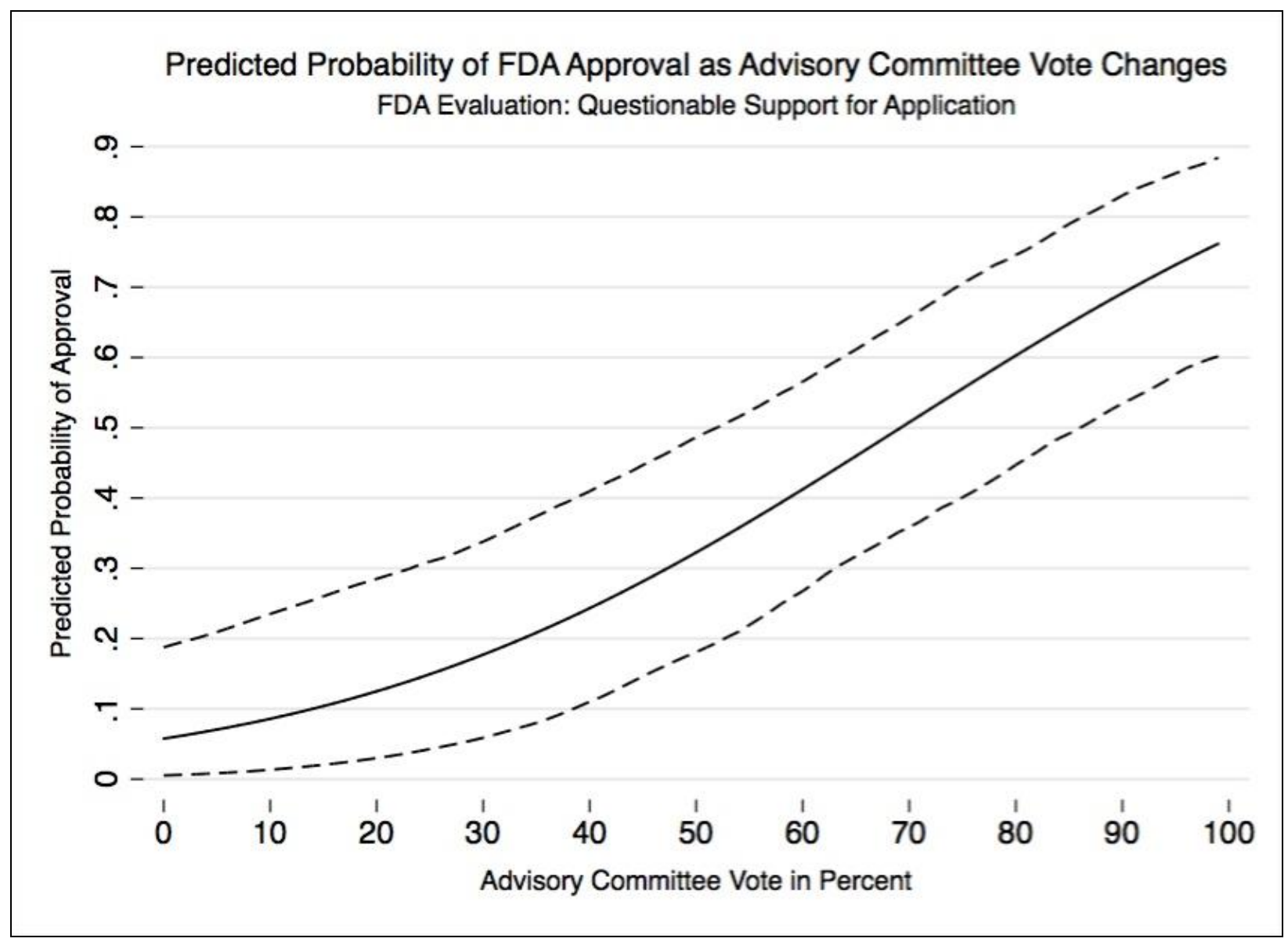

All dichotomous variables set at median, continuous variables set at mean, FDA Evaluation of Efficacy and Safety set at 2 , which reflects uncertainty on efficacy and safety. 
To put a finer point on some of the other key findings, I have calculated some additional quantities of interest. If the number of interests groups opposing approval (Interest Groups AntiApproval) increases from 0 to 1 , the probability of FDA Approval decreases by 22 percentage points (with a confidence interval of $16.8-27.1$ percent). ${ }^{49}$ This indicates that interest group activity does significantly affect approval decisions, however, not in the way that one might have anticipated. We might expect that an increasing number of groups demanding access to a drug would have a strong and significant effect on the FDA's risk-benefit calculus for approval, but there is no evidence of this in the data. However, the input of groups opposing approval (Interest Groups Anti-Approval), usually professional associations or consumer groups, does significantly affect the probability of approval. However, to obtain a deeper understanding of the role of interest groups, future research would have to take into account the size and financial power of the different groups in question. There is also evidence that the FDA is considerably more cautious in post-Vioxx scandal world with the probability of approval decreasing by 23.4 percent points (with a confidence internal of $8.0-40.6$ percent) after $2003 .^{50}$

In conclusion, the empirical evidence from the FDA drug approval process suggests that input from expert advisory committees strongly and significantly affects the FDA's drug approval decisions — even after accounting for agency preferences. The committees are a source of information and career bureaucrats incorporate committee recommendations into their approval decisions. This evidence indicates that bureau chiefs might build a system of expert advisory committees to lower the costs of expertise acquisition.

${ }^{49}$ All dichotomous variables set at their median, and continuous variables set at their mean.

${ }^{50}$ All dichotomous variables set at their median, and continuous variables set at their mean. 


\section{Caveats}

There are two alternative explanations for an agency's decision to construct expert advisory committees. The first is that political actors create advisory committees as mechanisms of political control, and the second is that agencies create advisory committee to achieve stakeholder buy-in. Building on the work of scholars who study the delegation of power from Congress to the bureaucracy, the first alternative explanation suggests that, just as Congress imposes procedural controls on agencies, agency leaders also implement procedural controls to limit the degree to which subordinate bureaucrats can move policy away from their preferred outcomes (McCubbins, Noll, Weingast, 1987, 1989; McCubbins and Schwartz 1984; Epstein and O’Halloran 1999). ${ }^{51}$ We could approach the relationship between agency leaders and their subordinates in much the same way that we think of the relationship between members of Congress and agencies. First, we know that career bureaucrats often have different ideological preferences than their principals, and therefore, the principals be concerned that their agents will shift policy away from that which they prefer (Clinton et al 2012; Aberbach and Rockman 2000; Golden 2000). We can likely further assume that career bureaucrats possess more information about the details of policy than agency secretaries. So, advisory committees could be an institutional strategy to minimize information asymmetries between agency leaders and subordinate bureaucrats by empowering external experts to monitor their decisions.

A straightforward story of political control is unlikely in the case of expert advisory committees. If those agency leaders believed that existing agency expertise was sufficient, but feared only that ideologically divergent career bureaucrats would push policy away from what

\footnotetext{
51 There is extensive literature on when Congress will impose procedures and the effects of those procedures on policy outcomes: Epstein and O'Halloran 1999; Bawn 1995; Huber and Shipan 2002; Shipan 2004; Volden 2002; McDonald 2010; Balla 1998; Yackee and Yackee 2006; Farhang 2010; Carpenter, Chattopadhyay, Moffitt and Nall 2012.
} 
they would prefer, then it is unlikely that the agency leadership would require public consultation with technical experts for two reasons. First, the institutional position of agency secretaries vis-avie career bureaucrats is different from that of members of Congress. Agency secretaries will not wish to expose conflict with career bureaucrats in a public forum. This exposed conflict could lead to unwanted attention from Congress, especially in periods of divided government. Second, by publicly bringing in a committee of qualified external experts, agency secretaries open their decisions to a group of credible critics who can challenge the technical analysis on which agency policy is based. It is unlikely that the agency would expose itself in this way unless it was making informational gains. ${ }^{52}$

It is possible that agency secretaries are created to exert a more subtle form of control. In considering whether or not to approve a drug, agencies first need to keep unsafe or ineffective drugs off the market. But there will be a range of new drug applications where there is uncertainty about what the correct regulatory decision is. In these cases, the agency must balance between Type 1 and Type 2 error or between approving unsafe drugs and keeping lifesaving drugs off the market, and we can assume that different agency secretaries and presidential administrations will have different preferences about where the agency should fall on this tradeoff. Bureaucrats ask expert committees to weigh in on both the interpretation of the clinical trials as well as on the ultimate question of approval. So advisory committee members are asked to use their expertise to (1) improve the agency's assessment of the relationship between a policy (approval of the drug) and its likely effect and (2) for their views on the appropriate balance between these two types of error. It is likely that experts - in this case medical researchers and

\footnotetext{
${ }^{52}$ In a previous chapter of the dissertation, I directly test this possibility by examining the effect of ideological distance on the decision to create expert advisory committees. Analysis finds no relationship between ideological distance and the decision to create advisory committees.
} 
practicing doctors - vary in their assessments about the appropriate tipping point for approval. As such, agency leaders may choose to appoint individuals who can lend their expertise to the agency as well as push the CDER to be either more aggressive or cautious in approving new therapies. Additional analysis is required to determine if this is, in fact, an additional use of advisory committees.

A second possibility is that agencies care deeply about their public reputation and that advisory committees are a mechanism for improving or maintaining that reputation. In Power and Reputation, Carpenter (2010) briefly discusses development of advisory committees in the FDA mainly during the 1960's and early 1970's (303-315). He concludes that advisory committees in this period provided an institutional forum for the agency to liaison with the scientific and medical researchers. He argues that the FDA sought to build relationships with members of the scientific community in order to communicate agency policy and develop support for the agency's policies among these individuals. He frames the use of advisory committees as a tool for reputation-building, because they have the potential build important alliances and to defuse credible critics of the agency.

Agencies face pressure from interest groups and the pharmaceutical industry to approve new therapies, and it could be that the agency builds alliances with research scientists and practitioners to resist pressures from these groups. This consensus can then serve to limit opposition from critics outside the agency. Carpenter is examining advisory committees at a time when the powers of the FDA were newly expanded following the 1962 Kefauver-Harris Amendments to the Federal Food, Drug and Cosmetic Act. ${ }^{53}$ This motivation for creating

\footnotetext{
${ }^{53}$ The Kefauver-Harris amendments required that the FDA now establish a drug's efficacy in addition to safety prior to granting market approval. The legislation also set the two clinical trial standard for new drug applications.
} 
advisory committees is more likely to be important at a time when agencies have been granted new powers and are regulating products in new ways, but less of a factor at times when the powers and regulatory standards of the agency have been accepted. Nonetheless, it is possible that this is a complementary motivation for creating advisory committees. Further investigation is necessary to determine whether committees also serve this purpose.

\section{CONCLUSION}

When agency secretaries assume their positions, they must assess whether the career staff they rely upon for policy analysis possesses sufficient expertise, especially in highly technical areas. If they question the sufficiency of agency expertise, they may adopt different strategies, including the creation of advisory committees. Advisory committees are an appropriate strategy if agency secretaries believe that they need to lower the cost of expertise acquisition.

The paper predicted that if advisory committees were created to lower the costs of information and expertise, then advisory committee recommendations would affect policy outcomes. Agency leaders in the FDA have constructed committees of outside experts and the preceding statistical analysis indicates that committees substantially affect drug approval decisions. When advisory committees send a strong signal for approval and the FDA is uncertain, the drug will likely be approved.

This paper provides evidence that when agency policymaking is highly technical, agency leaders create advisory committees to supplement expertise and introduce their own sources of information into the policymaking process. This complicates Balla and Wright's conclusion that Congress can control agency outputs by using advisory committees to manage the content and flow of information into the bureaucracy (2001). Congress can affect the informational inputs, 
but they do not have monopoly control over agency sources of information. Ultimately, they can affect but not completely control that agency's information environment. Agency leaders also have the power to create their own committees of stakeholders and experts to shape the policymaking decisions of subordinate bureaucrats. So agency secretaries have the authority to respond to congressional attempts to bias the decision-making environment by creating their own committees to counter that bias. This suggests that our theories about Congressional control of the bureaucracy through procedural mechanisms must recognize that agency leaders develop strategies to guide agency outputs as well. 


\section{WORKS CITED}

Aberbach, Joel D. and Bert A. Rockman. 2000. In the Web of Politics: Three Decades of the U.S. Federal Executive. Washington, D.C.: Brookings Institution Press.

Balla, Steven J. 1998. "Administrative Procedures and Political Control of the Bureaucracy." The American Political Science Review 92: 663-673.

Balla, Steven J. and John Wright. 2001. "Interest Groups, Advisory Committees, and Congressional Control of the Bureaucracy." American Journal of Political Science 45: 799-812.

Bawn, Kathleen. 1995. "Political Control Versus Expertise: Congressional Choices About Administrative Procedures." American Political Science Review 89: 62-73.

Bertelli, Anthony M. and Christian R. Grose. 2011. "The Lengthened Shadow of Another Institution? Ideal Point Estimates for the Executive Branch and Congress." American Journal of Political Science. 55: 766-780.

Bertelli, Anthony M. and Christian R. Grose. 2009. "Secretaries of Pork? A New Theory of Distributive Public Policy." American Journal of Political Science. 71: 926-945.

Brehm, John and Scott Gates. 1997. Working, Shirking, and Sabotage. Ann Arbor, MI: University of Michigan Press.

Carpenter, Daniel. 2002. "Groups, the Media, Agency Waiting Costs, and FDA Drug Approval." American Journal of Political Science 46: 490-505.

Carpenter, Daniel. 2010. Reputation and Power: Organizational Image and Pharmaceutical Regulation at the FDA. Princeton, N.J.: Princeton University Press.

Carpenter, Daniel. 2001. The Craft of Bureaucratic Autonomy: Reputations, Network, and Policy Innovation in Executive Agencies, 1862-1928. Princeton, N.J.: Princeton University Press.

Carpenter, Daniel, Jacqueline Chattopadhyay, Susan Moffitt and Clayton Nall. 2012. "The Complications of Controlling Agency Time Discretion: FDA Review Deadlines and Postmarket Drug Safety.” American Journal of Political Science 56: 98-114.

Clinton, Joshua D., Anthony Bertelli, Christian R. Grose, David E. Lewis, and David C. Nixon. 2012. "Separated Powers in the United States: The Ideology of Agencies, Presidents, and Congress.” American Journal of Political Science 56(2): 341-354.

Clinton, Joshua D., and David E. Lewis. 2008. "Expert Opinion, Agency Characteristics, and Agency Preferences." Political Analysis 16(1): 3-20. 
Epstein, David and Sharyn O'Halloran. 1999. Delegating Powers: A Transaction Cost Politics Approach to Policy Making Under Separate Powers. New York: Cambridge University Press.

Farhang, Sean. 2010. The Litigation State. Princeton, NJ: Princeton University Press.

Gailmard, Sean and John W. Patty. 2012. Learning While Governing: Expertise and Accountability in the Executive Branch. Chicago: Chicago University Press.

Gailmard, Sean and John W. Patty. 2007. "Slackers and Zealots: Civil Service, Policy Discretion, and Bureaucratic Expertise." American Journal of Political Science 51: 873889.

Gallo, Nick and David E. Lewis. 2012. " The Consequences of Presidential Patronage for Federal Agency Performance." The Journal of Public Administration Research and Theory 22: 219-243.

Golden, Marissa M. 2000. What Motivates Bureaucrats? Politics and Administration During the Reagan Years. New York: Columbia University Press.

Howell, William G. and David E. Lewis. 2002. “Agencies by Presidential Design.” Journal of Politics. 64: 1095-1114.

Huber, Gregory A. 2007. The Craft of Bureaucratic Neutrality. New York: Cambridge University Press.

Huber, John D. and Charles R. Shipan. 2002. Deliberate Discretion?: The Institutional Foundations of Bureaucratic Autonomy. New York: Cambridge University Press.

Jasanoff, Sheila. 1990. The Fifth Branch: Science Advisors as Policy Makers. Cambridge, MA: Harvard University Press.

King, Gary, Michael Tomz, and Jason Wittenberg. 2000. "Making the Most of Statistical Analyses: Improving Interpretation and Presentation." American Journal of Political Science 44: 347-361.

Lavertu, Stephane and David L. Weimer. 2011. "Federal Advisory Committees, Policy Expertise, and the Approval of Drugs and Medical Devices at the FDA." Journal of Public Administration Research and Theory 21: 211-237.

Lewis, David E. 2003. Presidents and the Politics of Agency Design. Stanford, CA: Stanford University Press.

Lewis, David E. 2010. The Politics of Political Appointments. Princeton, N.J.: Princeton University Press. 
McCubbins, Mathew D., Roger G. Noll, and Barry R. Weingast. 1987. "Administrative Procedures as Instruments of Control." Journal of Law, Economics and Organization 6: 267-298.

McCubbins, Mathew D., Roger G. Noll, and Barry R. Weingast. 1989. "Structure and Process, Policy and Politics: Administrative Arrangements and the Political Control of Agencies." Virginia Law Review 75: 431-482.

McCubbins, Mathew D., and Thomas Schwartz. 1984. "Congressional Oversight Overlooked: Police Patrols versus Fire Alarms.” American Journal of Political Science 28: 165-179.

McDonald, Jason A. 2010. "Limitation Riders and Congressional Influence over Bureaucratic Policy Decisions.” American Political Science Review 104: 766-782.

Moe, Terry M. 2012. "Delegation, Control, and the Study of the Public Bureaucracy." The Forum 10: 1-45.

Moffitt, Susan L. 2010. "Promoting Agency Reputation through Public Advice: Advisory Committee Use in the FDA." The Journal of Politics 72: 880-893.

Niskanen, William A. 1971. Bureaucracy and Representative Government. Chicago: Aldine.

Olson, Mary K. 1999. “Agency Rulemaking, Political Influences, Regulation, and Industry Compliance." The Journal of Law, Economics and Organization 15: 573-601.

Pollack, Andrew. 2013. "F.D.A. Panel Advises Against Two Medicines to Treat Hot Flashes." New York Times, March 4. Accessed on June 16, 2013. http://www.nytimes.com/2013/ 03/05/business/fda-panel-advises-against-two-medicines-to-treat-hot-flashes.html.

Shipan, Charles R. 2004. "Regulatory Regimes, Agency Actions and the Conditional Nature of Congressional Influence.” American Political Science Review 98: 467-480.

Stephenson, Matthew C. 2007. "Bureaucratic Decision Costs and Endogenous Agency Expertise." The Journal of Law, Economics, \& Organization 23: 469-498.

Stephenson, Matthew C. 2008. "Evidentiary Standards and Information Acquisition in Public Law." American Economic Review 10: 351-387.

Stephenson, Matthew C. 2011. "Information Acquisition and Institutional Design." Harvard Law Review 124: 1422-1483.

Smith, Bruce L.R. 1992. The Advisers: Scientists in the Policy Process. Washington, D.C.: Brookings Institution Press.

Ting, Michael M. 2003. "A Strategic Theory of Bureaucratic Redundancy." American Political Science Review 47: 274-292. 
Tomz, Michael, Jason Wittenberg, and Gary King. 2003. CLARIFY: Software for Interpreting and Presenting Statistical Result. Version 2.1. Stanford University, University of Wisconsin, and Harvard University. Accessed at: http://gking.harvard.edu.

Tullock, Gordon. 1971. The Logic of the Law. New York: Basic Books.

U.S. Environmental Protection Agency. “About BOSC.” Last modified June 29, 2013: http://epa.gov/osp/bosc/about.htm

U.S. Environmental Protection Agency. "BOSC Reports and ORD Responses." Last modified June 29, 2013: http://epa.gov/osp/bosc/reports.htm

U.S. General Services Administration. "Spending on Advisory Committees." Last modified: June 2013 http://www.gsa.gov/portal/content/249013.

U.S. General Services Administration. "What is the Composition of Advisory Committees." Last modified: June 2013 http://www.gsa.gov/portal/content/249049.

U.S. Office of Personnel Management. Fedscope Database. Last modified June 2013: http://www.fedscope.opm.gov/.

Volden, Craig. 2002. "A Formal Model of the Politics of Delegation in a Separation of Powers System” American Journal of Political Science 46: 111-133.

Volden, Craig. 2002. "Delegating Power to Bureaucracies: Evidence from the States." Journal of Law, Economics, and Organization 18: 187-220.

Yackee, Jason Webb, and Susan Webb Yackee. 2006. "A Bias Towards Business? Assessing Interest Group Influence on the U.S. Bureaucracy.” The Journal of Politics 68: 128-139. 


\section{APpendix A: CoDing Decisions}

THE SAMPLE: The sample includes every New Drug Application discussed and voted on by an advisory committee between 2001 and 2008. The sample also includes drugs that were being considered for market withdrawal if the committee voted on question. The sample excludes any drug where: 1) the committee discussed an NDA but did not vote, 2) the committee discussed general issues around a specific drug or class of drugs, 3) the committee discussed and/or voted on the appropriate clinical endpoints for a successful NDA application. Advisory committees within the FDA sometimes meet to discuss endpoints for the clinical trials or what results a clinical trial would need to be considered effective. It was not possible to also estimate the effect of advisory committees on this important aspect of FDA decision-making, because unlike drug approval, clinical endpoints for different NDA's are not publicly available.

FDA APPROVAL $(\text { FDAApp })^{54}=1$ if the drug is approved within two years of the advisory committee vote, otherwise 0 . If the decision to approve comes more than two years after the vote, it is likely that the sponsor produced additional research and the decision that was being considered at the time of the advisory committee vote was not to approve.

\footnotetext{
${ }^{54}$ The bold faced terms are those of the variable in the text of the paper. However, in the computer code I used shortened abbreviations. For each variable, I indicate variable name in the text of the paper and then the abbreviation used in the Stata code in parentheses. . For example, FDAApp was the abbreviation used for FDA Approval in the code.
} 
ADVISORY CommitTEE Vote (AdComVote) $=$ percent of an advisory committee voting in favor of the application. An NDA may be requesting approval for a new drug (or new molecular entity), approval for a new indication of an already approved drug, a new formulation for an already approved drug, or a switch to over-the-counter status. I also included votes on whether or not withdraw from an already approved drug from the market, and in this case, a vote to leave a drug on the market was considered a vote to approve. In most of cases (126 cases), the committee votes directly on approval. In 19 cases, the committee voted separately on safety and effectiveness, and in those cases, I averaged the two votes. In 15 cases, the committee only voted on safety or efficacy, and in those cases, I coded the efficacy or safety vote as the advisory committee vote. This is reasonable, because if either efficacy or safety is in doubt the drug cannot be approved. Finally, abstentions were dropped when calculating the percent voting for approval. Two additional cases from heard by the Oncology Drugs Committee in 2002 were dropped from the sample due to missing data (no transcripts available) -NDA 125011- Bexxar and NDA 20498/S-012- Casodexo.

FDA EFFICACY AND SAFETY EVALUATION (FDAEffSaf3) = sum of FDA safety and efficacy evaluation. The variable is the sum of the FDA review team's preliminary assessment on whether the sponsor has sufficient evidence to demonstrate that the drug effectively and safely treats the proposed indication (disease or condition). First for efficacy, the variable is coded as: 0 , if the FDA concludes that the drug does not demonstrate efficacy, 1 if the FDA concludes the drug questionably demonstrates efficacy, and 2 if the FDA concludes the drug convincingly demonstrates efficacy. Evaluations of whether a drug is reasonably safe depends on the prognosis for the disease or condition the drug treats. So acceptable safety standards are always 
considered in relation to the proposed indication. The variable is coded as: 0 if the FDA concludes given available evidence and the severity of the proposed indication that there are serious safety concerns, 1 if the FDA concludes that given available evidence and the severity of the proposed indication, there are some safety concerns, and 2 if the FDA concludes that given available evidence and the severity of the proposed indication the drug is reasonably safe. The final code is a sum of the efficacy and safety evaluation.

If FDA does not present on safety or efficacy, it is assumed that they have no questions about those portions of the drug sponsor's application and find the drug safe and/or efficacious. This assumption is reasonable given comments by FDA reviewers in the transcripts of the meetings. They typically present only on the efficacy or safety of a drug when they have concerns or conclusions that differ from the claims made by the sponsor. If FDA present on safety but not efficacy, it is assumed that the FDA found the drug efficacious and efficacy variable is coded at $2(6 \mathrm{obs})$. If FDA presents on efficacy but not safety, then it is assume that there were no safety questions, and that they found the drug to be fairly safe and FDASaf3 will be coded as a 2 . Finally, there are 20 observations where the FDA does not present at all and these are coded as 2 .

INTEREST GROUPS PRO-APPROVAL (IntGrApp) = a count of the number of interest groups promoting approval of the NDA at open public hearing in committee meeting. This includes groups that advocate explicitly for approval of the drug or for the development and approval of drugs to treat that condition. These are most often disease interest groups or societies of health care professionals. I exclude from the count individual academic researchers, groups that receive all their funding from the sponsor, and individuals- usually patients or family of patients (many 
of whom are paid by the drug company). Groups must disclose their financial relationships with the sponsoring firm prior to speaking. I do not exclude groups that receive some funding from the sponsor. This is necessary because the vast majority of interest groups promoting research and new treatments for diseases receive money from an array of firms to support their education and outreach efforts.

INTEREST GROUPS ANTI-APPROVAL (IntGrDen) = a count of the number of interest groups promoting the rejection of the NDA during the open public hearing section of the advisory committee meeting. These groups are mostly health care professional associations or consumer safety organizations. I exclude from the count individuals, typically patients, family members of patients, and academic researchers.

Public Attention $($ Media $)=$ count of New York Times stories on a disease. The variable is a proxy for public concern for a disease or condition and is an estimate of public demand for treatments. I searched for articles about the disease in the two years prior to advisory committee meeting. In Lexus Nexus, I searched the disease name in headline, abstract and lead paragraph, and the name of drug anywhere in article. In the count, I only included articles that discussed treatments options for the disease, the prevalence of disease, or money being allocated to fight the disease. I excluded articles about the general welfare of the companies that produce drugs, cost shifts in production of the drug in question, and other drugs that treat that disease. The focus was on demand for the treatment of disease so the measure counts the number of news articles highlighting this disease. 
PUBLIC CRITICISM (PubCrit) $=1$ if there has been public criticism questioning safety or efficacy of drug in the New York Times prior to the FDA's decision on NDA. For drugs not approved, the public does not have access to the date of the decision, unless it has been covered in the media or revealed by the drug company. I search for public criticism up to the two years prior to the advisory committee's recommendation.

POST-VIOXX SCANDAL (PostVioxx) = 1 if NDA review occurs in 2003 or after. Reports of adverse events related to the Vioxx begin to emerge at the end of 2001, but criticisms of the FDA do not gain momentum until 2003 and the drug is ultimately withdrawn in 2004.

YEAR OF VOTE $($ VoteYear $)=$ the year of advisory committee met to discuss and vote on the NDA.

COMMITTEE $($ Comm $)=$ indication of which committee reviewed the drug application. If NDA was considered by more than one committee, it was coded as reviewed by the primary therapeutic treatment committee. Typically, if approval was discussed by multiple committees, the second committee was either Nonprescription Drugs or Drug Safety and Risk Management in addition to a therapeutic treatment committee, like Oncology or Arthritis.

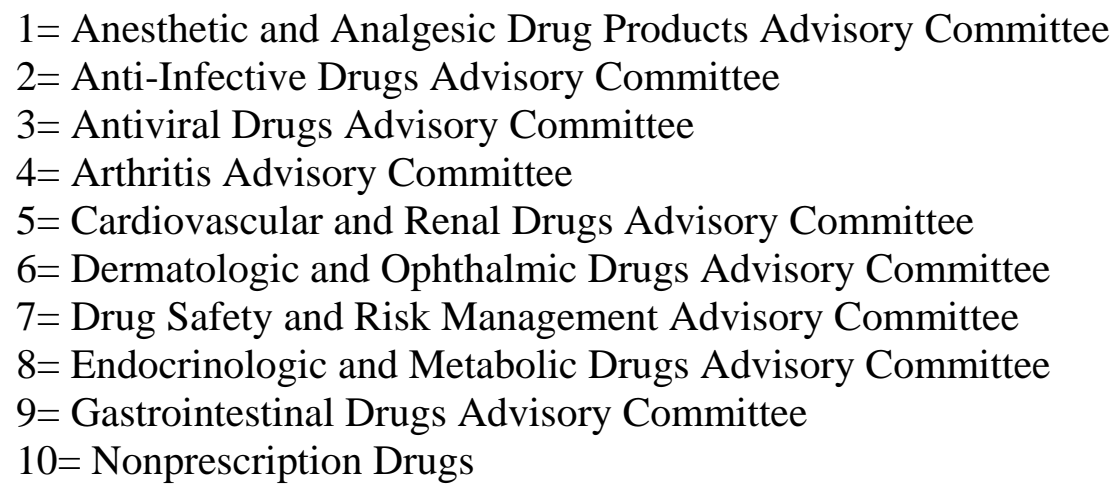


$11=$ Oncologic Drugs Advisory Committee

$12=$ Peripheral and Central Nervous System Drugs Advisory Committee

$13=$ Pharmaceutical Science and Clinical Pharmacology Advisory Committee

14= Psychopharmacologic Drugs Advisory Committee

$15=$ Pulmonary-Allergy Drugs Advisory Committee

16= Reproductive Health Drugs Advisory Committee 


\section{ApPendix B: Alternative Model Specifications}

\section{TAble 1. Determinants of Drug Approval With Alternative FDA Evaluation CODING}

\begin{tabular}{|l|c|}
\hline \multicolumn{1}{|c|}{ Variable } & $\begin{array}{c}\text { Alternative Coding for } \\
\text { FDA Evaluation }\end{array}$ \\
\hline Advisory Committee Vote & $.023^{* *}$ \\
FDA Safety and Efficacy & $.005)$ \\
Evaluation 2 & $.279^{*}$ \\
Interest Groups For Approval & $(.110)$ \\
Interest Groups Against & .073 \\
Approval & $. .057)$ \\
& $-.605^{* *}$ \\
Public Attention (log) & $.072)$ \\
& -.012 \\
Public Criticism & $(.095)$ \\
& $.857^{* *}$ \\
Post-Vioxx Scandal & $(.304)$ \\
\hline N & $-.673^{*}$ \\
Wald $\chi 2$ & $(.264)$ \\
Pseudo R2 & 162 \\
Percent Correctly Predicted & 249.04 \\
\hline
\end{tabular}

This model employs an alternative coding of the FDA safety and efficacy variable. I drop from the sample any observation where the FDA does not present at the advisory committee meeting rather than assuming non-presentation as a sign of support for the application.

* Variable is significant at the .05 level

** Variable is significant at the .01 level

+ Models employs clustered standard errors on advisory committee 


\title{
ADVISORY COMMITTEES AND THE DEVELOPMENT OF EXPERTISE IN THE FDA
}

\begin{abstract}
This paper argues that when faced with the challenge of developing and maintaining expertise over pharmaceutical drug development the FDA's leadership turned to advisory committees. The FDA established advisory committees because information and expertise were difficult to acquire given the complexity of assessing the safety and efficacy of drugs, rapid technological change in drug development, limited resources, and competition over skilled labor. The development of committees in the FDA suggests that there is also a public relations motive behind creating advisory committees. When the FDA was unable to recruit eminent scientists to their permanent staff, they incorporated them into decisionmaking through consulting arrangements and advisory committees to enhance the public credibility of their policy choices.
\end{abstract}


To observers of pharmaceutical drug development, advisory committees are a regular feature of the Food and Drug Administration's (FDA) process for determining whether a new drug is granted market entry. They are a public and frequently commented on step in the approval process for many drugs. For example in June 2013, the New York Times reported on the Advisory Committee on Reproductive Drugs' assessment of two new drugs applications to treat hot flashes in menopausal women. ${ }^{55}$ They also reported that another committee was reassessing whether restrictions on the troubled diabetes drug, Avandia, should be lifted. ${ }^{56}$ In 2013, the FDA actively consulted with 50 advisory committees, 17 of which on work on drug regulation. ${ }^{57}$ The presence of these committees raises the question: why did the FDA construct this system of advisory committees and embed them within process for reviewing new drug applications? To probe this question, this paper will examine the historical development of committees in the agency.

Advisory committees are an institutional mechanism for soliciting information from private sector experts or stakeholder interests. With about 1,000 in operation, they are common not only in the FDA, but also in executive agencies across the executive branch. They may only provide agencies with information, and their recommendations do not hold the weight of law. ${ }^{58}$

${ }^{55}$ Andrew Pollack, "F.D.A. Panel Advises Against Two Medicines to Treat Hot Flashes," New York Times, March 13, 2013, accessed, June 16, 2013, http://www.nytimes.com/2013/03/05/ business/fda-panel-advises-against-two-medicines-to-treat-hot-flashes.html.

${ }^{56}$ Sabrina Tavernise and Katie Thomas. "F.D.A. to Reconsider Restrictions on Diabetes Drug," New York Times, June 2, 2013, Accessed on June 16, 2013, http://www.nytimes.com/2013/06/ 03/business/second-thoughts-on-safety-of-avandia-stir-a-dispute.html.

${ }^{57}$ U.S. Food and Drug Administration, “Advisory Committees," last modified June 16, 2013, http://www.fda.gov/AdvisoryCommittees/default.htm.

${ }^{58}$ Determination of action" on their recommendations must be made through the typical policymaking channels (the legislative process, the rulemaking process, or presidential directive) 
In the FDA, advisory committees institutionalized and regularized consultation between career bureaucrats and external experts, mainly medical researchers at academic institutions or teaching hospitals. This paper investigates the origins of advisory committees in the drug approval process. By doing so, it contributes to our understanding of bureaucratic decision-making in complex, technical policy areas.

The contemporary literature on delegation and bureaucratic policymaking has focused mainly on the strategies presidents and Congress employ to control bureaucratic agencies and the effects of these control mechanisms on policy. ${ }^{59}$ This work has examined how Congress as well as the president structure administrative procedure to limit bureaucrats' ability shift policy away from that which they prefer, through the use of notice and comment rulemaking, time limits, reporting requirements, limitation riders, and political appointees. ${ }^{60}$

More recent researchers have begun to think seriously about how agencies develop expertise and how political actors can structure decisionmaking to improve information

"unless otherwise specified" by Congress or the president. The Federal Advisory Committee Act, U.S. Public Law 92-463, 86 Stat 770 (1972).

${ }^{59}$ Mathew D. McCubbins, Roger G. Noll, and Barry R. Weingast, “Administrative Procedures as Instruments of Control," Journal of Law, Economics and Organization 6(1987): 267-298; Mathew D. McCubbins, Roger G. Noll, and Barry R. Weingast, "Structure and Process, Policy and Politics: Administrative Arrangements and the Political Control of Agencies," Virginia Law Review 75(1989): 431-482; Kathleen Bawn, "Political Control Versus Expertise: Congressional Choices About Administrative Procedures," American Political Science Review 89(1995): 62-73; David Epstein and Sharyn O'Halloran, Delegating Powers: A Transaction Cost Politics Approach to Policy Making Under Separate Powers, (New York: Cambridge University Press, 1999).

${ }^{60}$ Steven J. Balla, “Administrative Procedures and Political Control of the Bureaucracy,” The American Political Science Review 92(1998): 663-673; Daniel Carpenter, Jacqueline Chattopadhyay, Susan Moffitt and Clayton Nall, "The Complications of Controlling Agency Time Discretion: FDA Review Deadlines and Postmarket Drug Safety" American Journal of Political Science 56 (2012): 98-114; Sean Farhang, The Litigation State, (Princeton, NJ: Princeton University Press, 2010); David E. Lewis, The Politics of Political Appointments, (Princeton, N.J.: Princeton University Press, 2010); Jason A. McDonald, "Limitation Riders and Congressional Influence over Bureaucratic Policy Decisions." American Political Science Review 104 (2010): 766-782. 
gathering among career bureaucrats. ${ }^{61}$ There is also important historical work that considers how agencies develop expertise. In Chain Reaction, Balogh examines the way that expert debate affected policymaking at the Atomic Energy Commission after World War II. ${ }^{62}$ In both Reputation and Power and The Forging of Bureaucratic Autonomy, Carpenter identifies strategies that agencies adopt to develop a reputation for competence in their pursuit of power and autonomy. ${ }^{63}$ This paper aims to contribute to our understanding of how agencies, such as the FDA, acquire expertise when policymaking is complex and requires highly skilled labor.

The leadership of an agency must consider how to compel career bureaucrats, once hired, to maintain and expand their expertise over agency policy within the constraints of the civil service system. This challenge is made more difficult when: 1) there is rapid technological change requiring bureaucrats to constantly update their expertise, and 2) qualified, skilled personnel are difficult to recruit and retain because private sector job opportunities offer greater remuneration or prestige. These are the very conditions that plague the FDA as well as other agencies engaged in technical policymaking.

If we consider the research effort of a career bureaucrat to be a function of both the private marginal costs and benefits, then agency leaders can structure administrative procedure to manipulate these marginal costs and benefits. One strategy is to acquire more resources and hire more qualified individuals for whom the cost of securing information is lower. This strategy is

\footnotetext{
${ }^{61}$ Sean Gailmard and John W. Patty, Learning While Governing: Expertise and Accountability in the Executive Branch, (Chicago: Chicago University Press, 2012); Matthew C. Stephenson, "Bureaucratic Decision Costs and Endogenous Agency Expertise," The Journal of Law, Economics, \& Organization 23(2007): 469-498; Matthew C. Stephenson, "Information Acquisition and Institutional Design," Harvard Law Review 124 (2011): 1422-1483. ${ }^{62}$ Brian Balogh, Chain Reaction: Expert Debate \& Public Participation in American Commercial Nuclear Power, 1945-1975, (New York: Cambridge University Press, 1991). ${ }^{63}$ Daniel P. Carpenter, The Forging of Bureaucratic Autonomy (Princeton, NJ: Princeton University Press, 2001); Daniel Carpenter, Reputation and Power: Organizational Image and Pharmaceutical Regulation at the FDA (Princeton, NJ: Princeton University Press).
} 
plagued by two difficulties. First, agencies have finite resources, and they may not be able to recruit and retain highly qualified personnel, especially if their skills are in high demand. Second, once hired, the agency leadership needs to consider how to compel bureaucrats to continue to develop and update their expertise, which is more difficult when the policy area is subject to rapid technological change. ${ }^{64}$ Another strategy is to grant bureaucrats greater policy discretion (thereby increasing the private benefit of research) in exchange for the development of expertise. ${ }^{65}$ However, in highly technical policy areas, this may be insufficient, because those individuals that are highly motivated by policy rewards may not be the most capable. ${ }^{66}$

Alternatively, agencies may also adopt strategies to lower the marginal private costs of research effort. When recruiting the most highly skilled labor is not an option, advisory committees can serve to lower the costs of research for the bureaucrats the agency does hire. These committees institutionalize regular consultation with a panel of individuals each in possession of expertise that the agency can use to aid the permanent staff. The rest of the paper presents evidence that when the FDA struggled to acquire sufficient expertise internally, they developed a system of advisory committees to lower research costs for career bureaucrats working on pharmaceutical drug regulation.

The FDA has used advisory committees since the beginning of the $20^{\text {th }}$ century, but their role in agency decisionmaking became more bureaucratized and regularized throughout the mid1960s. ${ }^{67}$ As the FDA assumed more authority over pharmaceutical drug development, the agency struggled to acquire the skilled personnel necessary to meet new demands given limited

\footnotetext{
${ }^{64}$ Stephenson, "Information Acquisition and Institutional Design".

${ }^{65}$ Bawn, "Political Control Versus Expertise"; Epstein and O'Halloran, Delegating Powers; Gailmard and Patty, Learning While Governing.

${ }^{66}$ Stephenson, "Information Acquisition and Institutional Design".

${ }^{67}$ Carpenter, Power and Reputation, 307; Sheila Jasonoff, The Fifth Branch: Science Advisors as Policy Makers (Cambridge, MA: Harvard University Press, 199), 154.
} 
resources, the requirements of civil service, and technological change in drug development. The agency adopted numerous strategies to improve its scientific competence, including recruiting of new staff, improving workplace conditions, and seeking assistance from external experts. They first sought assistance from academic scientists in an ad hoc manner before incorporating them into agency policymaking more systematically through advisory committees. Over the course of the 1960s, the agency adopted strategy of systematizing and institutionalizing consultation with these external experts. By the beginning of the 1970s, the agency had built a system of committees each with its own staff and organized by therapeutic area advising the agency on new drug applications.

In addition, there is a public relations element to the FDA's use of advisory committees. ${ }^{68}$ As noted, agencies tried to recruit eminent scientists, but for the most part they failed to acquire them for the permanent staff. However, these scientists and medical researchers were willing to advise the agency as consultants and through committees. The agency felt that association with these scientists enhanced the credibility of their decisions.

This paper begins by providing a brief history of pharmaceutical drug regulation prior to the development of advisory committees. It then outlines the challenges the agency faced in acquiring sufficient expertise after the passage of the Kefauver-Harris Amendments in 1962. Next, it examines the development of early agency committees involved in pharmaceutical drug review, and how they evolved to become a regular fixture in the review of new drug applications. This will be accomplished by 1) providing an overview of the transition from consultants to

\footnotetext{
${ }^{68}$ In Power and Reputation, Carpenter argues that these committees are mainly instituted to build allies outside the agency. This association, he argues, improved the agency's reputation. He underplays the informational value of the committee for the FDA. I will prevent evidence that strongly suggests that these committees were serving an important informational role as well as a public one.
} 
committees, and 2) examining in greater depth some of the important, early committees, including the Advisory Committee on Investigational Drugs, the Drug Efficacy Study and the Over-the-Counter Drug Review.

\section{Brief History of Pharmaceutical Drug Regulation}

The federal government first began regulating pharmaceutical drugs with the Biologics Act of 1902 and the Food and Drugs Act of 1906. ${ }^{69}$ Although Congress granted the executive branch the authority to license producers in biologics, the Food and Drugs Act did not grant agencies the power to license drug manufacturers or to engage in any pre-market review of drugs. Instead, the 1906 law only provided the Bureau of Chemistry (the FDA's predecessor) the authority to remove adulterated or misbranded drugs from the market. From 1933 to 1937, Congress considered legislation that would strengthen the FDA's regulatory authority over pharmaceutical drugs, but no legislation succeeded in commanding enough support.

It took a tragedy, a mass poisoning due to the elixer sulfanilamide, to propel legislation through both houses. ${ }^{70}$ With the passage of the Federal Food, Drug and Cosmetic Act of 1938,

${ }^{69}$ There were also two earlier pieces of legislation. The Vaccine Act of 1813 appointed a federal official to "preserve the genuine vaccine matter and furnish the same to any citizen." The act was repealed in 1822 after a federal agent distributed a contaminated smallpox vaccine. The Import Drugs Act of 1848 required imported drugs be labeled with manufacturer, and inspected for quality so that imported adulterated or deteriorated drugs could be denied entry. Quoted in Peter Barton Hutt, "Investigations and Reports Respecting FDA Regulation of New Drugs (Part I)," Journal of Clinical Pharmacology and Therapeutics 33(1983), 537. See also: John Swann, "Sure Cure: Public Policy on Drug Efficacy Before 1962," in The Inside Story of Medicines: A Symposium, ed. Gregory J. Higby and Elaine C. Stroud, (Madison, WI: American Institute of the History of Pharmacy, 1997) 224.

${ }^{70}$ In the summer of 1937, the Massengill Company decided to offer sulfanilamide (an early antibiotic used to treat venereal disease and streptococcal infections) in a liquid form. However, they mixed the drug with a toxic solvent (diethylene glycol). As a result, more than 100 people died from poisoning. See, Daniel Carpenter and Gisela Sin, "Policy Tragedy and the Emergence of Regulation: the Food Drug and Cosmetic Act of 1938," Studies in American Political Development, 21(2007): 161-164; Phillip J. 
the FDA assumed responsibility over pre-market notification of new drugs. ${ }^{71}$ The act required that firms submit documentation of the drug's composition and evidence of screening on animals for toxicological effects. ${ }^{72}$ In addition, the law required that all new drugs be investigated in humans, but it did not specify in any detail the type of clinical investigation required of firms. After a firm completed the toxicological and clinical investigation, they submitted an application to the agency, and the FDA had to assess "by all methods reasonably applicable" whether a drug was "safe for use." 73 If the agency did not disprove the application within 60 days of filing (extendable up to 180 days), then the sponsoring firm was free to market the drug. ${ }^{74}$

Between 1938 and the Kefauver-Harris amendments in 1962, the agency was only technically responsible for ascertaining whether a drug was reasonably safe before granting it market entry. However, safety is inherently a relative concept. A drug that is safe for a person potentially dying of tuberculosis may not be considered safe for a person with the common cold depending on the balance between the severity of the side effects and the potential benefits

Hilts, Promoting America's Health: The FDA, Business, and One Hundred Years of Regulation, (Chapel Hill, N.C.: University of North Carolina Press, 2003), 89-93.

${ }^{71}$ For additional reading on legislative history see: James Harvey Young, The Medical Messiahs: A Social History of Health Quackery in the Twentieth-Century America, (Princeton, N.J.: Princeton University Press 1969), 158-190; David F. Cavers, "The Food Drug and Cosmetic Act of 1938: Its Legislative History and Substantive Provision," Law and Contemporary Problems 6.1(1939): 2-42; Charles O. Jackson, Food and Drug Legislation in the New Deal, (Princeton, N.J.: Princeton University Press, 1970).

${ }^{72}$ Federal Food, Drug, and Cosmetic Act, U.S. Public Law 75-717, 52 Stat 1040 (1938).

${ }^{73}$ Public Law 75-717, Sec. 505(d) 1938.

${ }^{74}$ Technically, the agency did not have the authority for approval, but could "refuse to permit application to become effective." U.S. Public Law 75-717 Sec. 505(d), 52 Stat 1040 (1938). For a helpful discussion of the law see: Harry M. Marks, The Progress of the Experiment: Science and Therapeutic Reform in the United States, 1900-1990, (New York: Cambridge University Press, 1997), 77. 
yielded by the drug. Given the relativity of safety as a concept, assessments of a drug's efficacy played a role in the FDA's review of new drug applications from the beginning. ${ }^{75}$

Through a series of rules in 1955 and 1956, the FDA began to specify with greater detail the data required for a New Drug Application (NDA) to be granted approval. ${ }^{76}$ The new application process required firms to supply more detailed data in replicable form, and present evidence of the therapeutic results observed. ${ }^{77}$ Although, they began to assume greater authority over drug development through these rule changes, they would not be granted full statutory authority to regulate both clinical investigation and drug efficacy until the Kefauver Harris Drug Amendments in $1962 .^{78}$

The 1940s and 1950s was a time of expansion in the complexity, number, and potency of pharmaceutical drugs. This time is often referred to as the therapeutic revolution, because it marked the discovery of penicillin, steroids, antihistamines, early anti-psychotics, chemotherapy among others important new drugs. The era also marked a time of rising profits for the drug industry. In 1959, following a Federal Trade Commission (FTC) investigation into drug pricing and profits, the Senate's Subcommittee on Antitrust and Monopoly, chaired by Senator Estes

\footnotetext{
${ }^{75}$ Marks, The Progress of the Experiment, 75-80, 95-97; Carpenter, Reputation and Power, 115-116; Swann "The Sure Cure". The extent to which the FDA was regulating drugs based on efficacy prior to explicit statutory to do so is the subject of some debate. Evidence presented by both Marks and Carpenter suggests that efficacy was an important part of the FDA's calculus from the beginning. They disagree about the extent to which the FDA was constrained by the absence of explicit statutory authority to regulate efficacy. Carpenter argues that the Kefauver-Harris Amendments essentially codified existing practice. However, Marks presents compelling evidence of instances when the agency was checked when it tried to reject applications or remove products from the market on efficacy grounds alone. Marks The Progress of the Experiment, 95-97. See also: Charles Wesley Dunn and Vincent A. Kleinfeld, Federal Food, Drug and Cosmetic Act, 1939-1949, (New York: Commerce Clearing House, 1949).

${ }^{76}$ Carpenter, Reputation and Power, 157.

${ }^{77}$ Carpenter, Reputation and Power, 157-158.

${ }^{78}$ Drug Amendments Act of 1962, U.S. Public Law 87-781, 76 Stat. 780 (1962).
} 
Kefauver (D-TN), began investigating the drug industry. ${ }^{79}$ This investigation was part of a broader inquiry into economic concentration that began in $1956 .{ }^{80}$ This investigation also coincided with rising health care costs, and complaints about drug firm's aggressive advertising practices from prominent members of the medical field. ${ }^{81}$ Fiercely critical of the drug industry, Senator Kefauver introduced a comprehensive reform bill (S.1552) in the spring of $1961 .^{82}$ The main features of the bill focused on limiting patent protections, advertising and trade name reform, new licensure requirements, as well as premarket approval for all drugs based upon evidence of safety and efficacy. ${ }^{83}$ However, the bill lacked sufficient support in the Senate to proceed and was seemingly dead until another policy tragedy struck — thalidomide.

The American firm Richardson-Merrell licensed thalidomide from Chemie Grunenthal, a German firm, in $1958 .^{84}$ Thalidominde was the active ingredient in a sleeping pill. According to government estimates, Richardson-Merrell distributed the drug to about 16,000 patients (including 624 pregnant women) for clinical investigation. ${ }^{85}$ The firm submitted a new drug

\footnotetext{
${ }^{79}$ In 1959, FTC and Securities and Exchange Commission (SEC) found that the profits of drug industries profits were higher than those of other manufacturing industries. For example their profits as a percent of sales were 4.8 percent versus 10.3 percent. Dominique A. Tobbell, Pills, Power and Policy: The Struggle for Drug Reform in Cold War America and Its Consequences, (Berkeley and Los Angeles, CA: The University of California Press, 2012), 73.

${ }^{80}$ Meg Jacobs, Pocketbook Politics: Economic Citizenship in the Twentieth Century. (Princeton, N.J.: Princeton University Press, 2005) 246-261; Daniel Scroop, "A Faded Passion? Estes Kefauver and the Senate Subcommittee on Antitrust and Monopoly," Business and Economic History Online. 5 (2007): 117, accessed April 27 2013, http://eprints.gla.ac.uk/76669/.

${ }^{81}$ On price increases in the 1950s see: U.S. Department of Health, Education and Welfare. Health United States 1975. DHEW Publication no. (HRA) 76-1232, 11-16. On an example of criticism on advertising practices, see: Harry F. Dowling, "Twixt the Cup and the Lip," Journal of the American Medical Association. 165(1957): 657-661. For a discussion on criticisms of the drug industry at this time, see: Tobell Pills, Power, and Policy, Chapter 3.

${ }^{82}$ For a legislative history of the Kefauver Harris Amendments, see: Richard Harris, The Real Voice, (New York: Macmillan Company, 1964)

83 Tobell, Pills, Power, and Policy, 89-120.

${ }^{84}$ Hilts, Promoting America's Health, 149

${ }^{85}$ Arthur Daemmrich, "A Tale of Two Experts: Thalidomide and Political Engagement in
} 
application to the FDA, but approval to distribute the drug on a wider scale was held up by a medical officer-Frances Kelsey—-for lack of evidence. ${ }^{86}$ At this time the drug was already on the market in Germany. Soon after Kelsey delayed the application, reports from Germany revealed that the drug was responsible for severe birth defects in children whose mothers took the drug during pregnancy. The birth defect caused by the drug is called 'phocomelia', which comes from the Greek for seal extremities. Children with this defect were born with shortened extremities, including hands and feet emerging directly from the torso ${ }^{87}$ It is estimated that the drug was responsible for approximately 4,000 deformed children in Germany and 17 in the United States ${ }^{88}$ Following this tragedy, drug reform became an important issue, and President Kennedy pushed for a bill. Kefauver's bill was revived, but it was stripped of the provisions intended to control drug prices, including patent and trade name reform. The narrower bill focused on improving the safety of drugs by assuming regulatory authority over the investigational period of a drug, requiring that any new drug demonstrate efficacy as well as safety, and a mandate that firms distribute information about negative side effects along with the drug. The bill, now co-sponsored with Representative Oren Harris (D-AR), passed both houses unanimously and was signed by the president in October of 1962 .

The Kefauver Harris Amendments expanded regulatory authority over medical experimentation, standards of evidence required for market entry, and the advertising of

the United States and West Germany," The Society for the Social History of Medicine 15(2007), 139. Estimates of the number of patients taking the drug range as high as 20,000. Neither Richardson Merrell nor many of their clinical investigators kept good records on the number and name of the patients they distributed the drug to. Hilts Protecting America's Health, 156; Tobell, Pills, Power and Policy, 125-126.

${ }^{86}$ Daemmerich, "A Tale of Two Experts," 152-157; Carpenter Reputation and Power, 235-260. Kennedy later awarded Kelsey with the Distinguished Federal Civilian Service Award.

${ }^{87}$ Daemmerich, "A Tale of Two Experts," 138.

${ }^{88}$ Daemmerich, "A Tale of Two Experts," 138. 
approved drugs. ${ }^{89}$ First, the FDA was now responsible for regulating the clinical trial phase of drug development. The amendments required that the FDA set standards for clinical trials. The agency published regulations on the new requirements for investigational drugs in the Federal Register in 1963. These rules required that firms gain approval prior to commencing experimentation through the new Investigational New Drug (IND) application. Although the FDA had increased the standards of evidence for clinical research with the 1955 regulations, they now began to regulate how experiments were conducted during trials. The agency prescribed study protocols (including requiring informed consent of study subjects) that firms had to adopt before they could move forward with clinical investigation of a new drug. Notably, the FDA developed the three phase clinical trial at this point. ${ }^{90}$ The legislation also required that "experts qualified by scientific training" carry out clinical investigations, which gave the agency the authority to regulate the qualifications of those involved in carrying out experimentation. ${ }^{91}$

Second, the new legislation required that firms applying for market approval produce evidence from "adequate and well-controlled investigations" that a drug was safe and effective." ${ }^{92}$ Although the FDA had been in some way assessing drug efficacy since the 1938 amendments, they were now granted statutory authority to reject applications for drugs that were of no therapeutic value even if they were judged as safe. In addition, they were empowered to

\footnotetext{
${ }^{89}$ The agency could now require manufacturers to report adverse events, and to inspect manufacturer complaint files. A drug's approval could then be withdrawn with evidence establishing the drug was unsafe. U.S. Department of Health, Education, and Welfare, Annual Reports on the administration of the Federal Food, Drug, and Cosmetic Act and related laws, 1950-1974, (Washington, D.C.: Government Printing Office, 1976) 313.

${ }^{90}$ For a description of the development of the three phase clinical trials, see: Carpenter, Reputation and Power, 275-277.

${ }^{91}$ U.S. Public Law 87-781 (1962).

${ }^{92}$ Ibid.
} 
define what "adequate and well controlled investigations" meant as well as what constituted a reasonably safe and effective drug. ${ }^{93}$

Between 1938 and 1962, the FDA through both agency initiative and legislation came to assume more authority over the development of pharmaceutical drugs and greater regulatory gatekeeping powers over market entry. As noted, this increase in authority came at a time where there were also rapid advances clinical pharmacology and drug development. These advances were coupled with a shortage of skilled pharmacologists as well as doctors trained in scientific methods. ${ }^{94}$ This increase in authority coupled with rapid technological change raises questions about whether and how the FDA acquired sufficient information and expertise to effectively regulate drug development.

\section{EFForts to BuILd AgenCy CAPACITY}

Between the 1938 Food, Drug and Cosmetic Act and the 1962 Kefauver Harris Amendments, the FDA took steps to augment agency expertise and build scientific capacity. Through this time and especially following the passage of the 1962 Amendments, members of Congress, academic scientists as well drug firms questioned the scientific competence of the agency. One strategy for improving internal capacity was to augment agency resources and improve the quality of personnel. The agency pursued this strategy, but was limited by

\footnotetext{
${ }^{93}$ Ibid.

${ }^{94}$ Tobell, Pills, Power and Policy, 55-57, 125-130. Both drug firms and the FDA needed clinical pharmacologists. However, there were few schools that offered training in clinical pharmacology at the time. Johns Hopkins and University of Pennsylvania being the main examples. This problem would only become exacerbated following the passage of the 1962 amendments. The new IND regulations that introduced the three phase trials required firms produce data and analysis for each phase. Firms needed clinical pharmacologists to produce the data and analyses, and the FDA needed them to evaluate the data submitted by the firm. Tobell, Pills, Power and Policy, 126.
} 
insufficient funds from Congress, competition for skilled labor, and the difficulty of keeping pace with rapid technological change. The agency then pursued a second strategy of using consultants from the private sector and eventually assembling these private sector experts into committees.

In the early 1950's, by the agency's own estimation, its resources “were never adequate and remained at approximately the levels prevailing in 1938." ${ }^{.95}$ Each year between 1951 and 1954 , the agency was receiving less than the amount requested in their budget proposal, and as a result, had to reduce personnel by 15 percent over this period. ${ }^{96}$ There were also fewer enforcement personnel in 1955 than 1941. Facing insufficient funds from Congress and concerns over the lack of agency capacity, Commissioner Charles Crawford and Secretary of the Department of Health, Education, and Welfare (HEW) Oveta Culp secured funds for a study of the FDA's capacity in 1955. Following the report of this committee (called the Citizen's Advisory Committee), the agency received a four fold increase in funds between 1955 and $1963 .{ }^{97}$ With the increase in appropriations, the agency nearly tripled its staff from 1,027 to 3,012 employees. ${ }^{98}$ Bureau of Medicine employees increased from 39 to 108, and biological and physical sciences employees rose to 482 from $125 .{ }^{99}$

95 U.S. Department of Health, Education, and Welfare, Annual Reports, xii)

${ }^{96}$ U.S. Department of Health, Education, and Welfare, Report of Second Citizen's Advisory Committee on the Food and Drug Administration to the Secretary of Health, Education, and Welfare, (Washington, D.C.: Government Printing Office) 2-3.

97 The committee sharply decried the agency's resources as "woefully inadequate" and recommended a three to four fold increase in funding for the agency in order to hire more qualified personnel and improve facilities and equipment. U.S. Department of Health, Education, and Welfare, Citizen's Advisory Committee on the Food and Drug Administration, (Washington, D.C.: Government Printing Office ,1955), 5, 53.

${ }^{98}$ U.S. Dept. of Health, Education, and Welfare, Report of Second Citizen's Advisory Committee, $2,4,32$.

99 Ibid. 
Following the expansion of the FDA authority in 1962, the agency requested and received another substantial increase in appropriations. Appropriations rose from $\$ 23$ million to \$28.3 million, which permitted the addition of more personnel, a new integrated data processing system, improvements to office facilities, a new animal laboratory, and modernized scientific equipment. ${ }^{100}$ In 1963, the agency reorganized in order to "upgrad[e] scientific functions."101 The reorganization created two new bureaus to coordinate the agencies scientific activitiesBureau of Scientific Research and the Bureau of Scientific Standards and Evaluation. In addition, the agency's announcement of the reorganization publicized the creation of a committee to "advise the Administration on national needs and the effectiveness of program policies." ${ }^{, 102}$

Despite these increases in appropriations and staff, the agency struggled to secure enough skilled manpower to implement the 1938 law and later 1962 Amendments for three reasons. First, despite increases in appropriation, resources from Congress remained insufficient. Second, technological change put a premium on certain training, particularly clinical pharmacology, that was undersupplied and the FDA faced stiff competition from academia and drug firms for their labor. Lastly, given the rate of technological advance and rising workload, it was difficult for staff to stay abreast of new advances and techniques. ${ }^{103}$ Given the requirements of the civil service system, the agency was limited in its ability to replace those with outdated training.

\footnotetext{
${ }^{100}$ Personnel for enforcement increased by 342 positions from 1,518 to 1,8600 , and 126 new employees were added to the main office. U.S. Dept. of Health, Education and Welfare, Annual Reports, 318-319.

${ }^{101}$ Press Release of Department of Health Education and Welfare, "For Release in A.M. Papers, Saturday, November 2, 1963," Harry F. Dowling Papers, National Library of Medicine Bethesda, MD, Box 5, Folder 'FDA Structure'.

${ }^{102}$ Ibid.

${ }^{103}$ The FDA had established some training programs to keep scientific staff abreast of new advances. In 1962, they estimated that training programs for scientists, inspectors, supervisors,
} 
Throughout the 1940s and 1950s, the agency began to recruit new staff members that had Ph.D.s in fields such as pharmacology as well as individuals with medical degrees. ${ }^{104}$ As the importance of pharmacology rose in the evaluation of new drug applications, the agency began recruiting students trained by the prominent academic pharmacologist Eugene M.K. Geiling. ${ }^{105}$ The agency developed recruitment programs for promising college graduates and sought advice from prominent figures in academic medicine on how to improve the quality of personnel. ${ }^{106}$ However, the agency possessed limited resources and faced competition from universities and the pharmaceutical firms for skilled labor. ${ }^{107}$ In Pills, Power, and Policy, Tobell documents that large, respected pharmaceutical firms of the era, like Merck \& Co., developed strategies to acquire qualified scientists by establishing fellowships at medical schools, offering sabbaticals and exchanges with universities as well as developing a wide network of part-time consultants to acquire expertise.

In a review of the FDA's capacity commissioned by the Secretary of Health, Education, and Welfare, an external committee concluded that the Bureau of Medicine had a "chronic"

administrators and clerical employees were attended by approximately 3,000 personnel. U.S. Dept. of Health, Education, and Welfare, Annual Reports, 320.

${ }^{104}$ Carpenter, Reputation and Power, 135.

${ }^{105}$ Carpenter, Reputation and Power, 133.

${ }^{106}$ U.S. Department of Health, Education, and Welfare, Annual Report, 320; Letter from Dr. Harry F. Dowling to Mr. Boisfeuillet Jones, July 11, 1963, Dowling Papers, Box 5, Folder 'History'.

107 The Citizen's Advisory Committee reported it was difficult for the agency to successfully recruit the best candidates, because of low salaries and prestige. They argued that in the New Drug Branch "additional staff cannot be quickly recruited or temporarily hired because of the technical nature of most of the work and the low salaries paid." For an example of the salary gap with the private sector, a top chemist (entry level) could earn $\$ 3,400$ a year at the FDA in comparison to $\$ 5,000$ a year in industry. They recommend that the "stature, prestige, and salaries of the professional personnel who must bear the burden of passing on new drugs should be increased." U.S. Department of Health, Education, and Welfare, Citizen's Advisory Committee, $2,40,42$. 
vacancy problem and that there was excessive turnover in important scientific positions. ${ }^{108}$ They further added that the Bureau of Biological and Physical Sciences struggled to recruit and retain qualified scientific personnel. They concluded that the quality of drug regulation would suffer unless "competent younger persons are brought to the fore," and the agency developed "closer professional relationships with university and other research centers." ${ }^{109}$ So, although the FDA was able to hire more personnel and made efforts at recruiting qualified personnel, they faced competition for that labor and had a difficult time both filling positions and retaining those individuals they did hire.

The agency also tried to improve scientific competence by building the agency's network of advisers and consultants. Although many new drug applications could be easily dealt with in house, the agency began reaching out to external experts for difficult or controversial decisions even in the earliest days of implementing the 1938 law. An example of this strategy can be seen in one of the first difficult cases the agency had to contend with-Merck \& Company's application for sulfapryidine. The heads of the Drug Division in the FDA at the time, Theodore Klumpp and J.J. Durrett, both had backgrounds in academic medicine, and they reached out prominent academics regarding the application. ${ }^{110}$

Throughout the 1950's this pattern of drawing up on expertise of those outside the agency became more common. The agency established consulting contracts with Eugene M.K. Geiling(University of Chicago), Maxwell Finland (Harvard University), Walter Modell (Cornell

\footnotetext{
108 The F.D.A. was lodged within HEW. U.S. Department of Health, Education, and Welfare, Report of the Second Citizen's Advisory Committee, 9, 51.

${ }^{109}$ U.S. Department of Health, Education, and Welfare, Report of the Second Citizen's Advisory Committee, 51.

${ }^{110}$ Marks, The Progress of the Experiment, 79, 84-89. Carpenter finds evidence that after tapping into their academic networks, they went further and surveyed or interviewed an additional 45 clinicians who had experience with the drug. Carpenter, Reputation and Power, 113.
} 
University), and Louis Lasagna (Johns Hopkins University) among others. ${ }^{111}$ These consultants formed an ad hoc system of information gathering. ${ }^{112}$ They reached out to these individuals when they had to contend with a difficult application. ${ }^{113}$ In an exchange of letters, both Dr. Maxwell Finland and Dr. Keith Cannan of the National Research Council (NRC) criticized the agency for seeking information in ad hoc manner:

For some years the Division has urged FDA to establish a continuing advisory structure and has objected to the habit of seeking advice only on an ad hoc basis when in a sticky situation. We have even expressed willingness to consider assuming this task if asked to do so. We have not been asked. The real need has been for advice on policy, practices, and procedures. The legal arm of the FDA has been too fearful of its prerogatives to seek this. ${ }^{114}$

The agency continued to use these advisors in an ad hoc manner until after the passage of the

Kefauver amendments. However, with the delegation of new authority came heightened scrutiny of the agency's scientific competence.

Debates over the new drug reforms aired much skepticism about the agency's capacity to implement the 1962 Amendments. Critics included politicians, prominent academic medical

${ }^{111}$ Geiling had performed consulting work for the FDA. The agency repeated tried to recruit throughout 1959 to join the agency as chief of the Pharmodynamics Branch in the Division of Pharmacology or to come to some consulting relationship. See: Letter from E.M.K. Geiling to John L. Harvey, June 20, 1961, E.M.K. Geiling Papers, Johns Hopkins School of Medicine, Baltimore, MD, Box 503520, Folder "Personal Correspondence - K II"; Letter from Robert S. Roe to Dr. E.M.K Geiling, May 21, 1959, Geiling Papers, Box 503520, Folder "Personal Correspondence - R"; Letter from E.M.K Geiling to Robert S. Roe, January 23, 1958, Geiling Papers, Box 503520, Folder "Personal Correspondence - R".

${ }^{112}$ For example, there was an ad hoc committee on antibiotics in 1963. Letter from Dr. William H. Kessenich Medical Director FDA to Maxwell Finland, June 26, 1962, Finland Papers, Box 2, Folder 24; Letter from Commissioner George P. Larrick to Maxwell Finland, August 13, 1963, Finland Papers, Box 2, Folder 24.

${ }^{113}$ For example, Dr. David S. Davis, Medical Officer at New Drug Branch, wrote to Finland to get his advice on the drug Altafur from Eaton Laboratories. Letter from Dr. David S. Davis to Dr. Maxwell Finland, September 27, 1960, Maxwell Finland Papers, Harvard Medical School, Boston, MA, Box 2, Folder 24; Letter from Dr. Maxwell Finland to Dr. David S. Davis, October 3, 1960, Finland Papers, Box 2, Folder 24; Carpenter, Power and Reputation, 134.

${ }^{114}$ Letter from R. Keith Cannan to Dr. Maxwell Finland August 22, 1963, Finland Papers, Box 4, Folder 4. 
researchers (including some who had consulted for the agency in the past), and drug firms. For example in 1962, Senator Hubert Humphrey (D-MN) proclaimed:

The 12-members of the New Drug Division cannot, all by themselves, effectively analyze 365 new drug applications a year. The entire Bureau, by itself, cannot evaluate the masses of information pouring in on drugs already on the market...FDA's own scientific program must be of the highest order. FDA's scientists, particularly in the Bureau of Medicine, must be brought into the mainstream of scientific endeavor, instead of being in the 'backwater'. 115

Boisfeuillet Jones, an adviser to Secretary Celebrezze on health and medical affairs, contended that the "sophistication of chemical compounds, the very rapid development in this field through research sponsored by pharmaceutical houses, and outside of the commercial range also" required the "best judgment" of both positive and negative side effects. ${ }^{116}$ He concluded that given this reality the FDA "neither then nor ever, would have the full range of competence to make these sophisticated judgments."117

Members of the FDA's network of consultants and advisors also questioned its capacity. ${ }^{118}$ In hearings leading up to the passage of the 1962 Amendments, Dr. Harry F. Dowling (University of Illinois School of Medicine) raised concern about the ability of the FDA given its resources to attract enough competent personnel. He advised the agency to appoint "a council of leading scientists, who would advise it regarding overall policies" and on specific

${ }^{115}$ Congressional Record. 1962. 87th Cong., $2^{\text {nd }}$ sess. Vol. 108, pt. 13: 17418.

116 Jones was appointed by Kennedy in 1961 to serve as "Special Assistant to the Secretary for Health and Medical Affairs". The position was to advise the Secretary on medical and "scientifically related activities." U.S. National Library of Medicine, "Interview with Boisfeuillet Jones", General History of Medicine Oral Histories, 1, 14, accessed at http://oculus.nlm.nih.gov/cgi/t/text/textidx $? c=$ oralhist $; c c=$ oralhist; $r g n=$ main; view $=$ text; $;$ idno $=2935135 \mathrm{r}$.

${ }^{117}$ U.S. National Library of Medicine, "Interview with Boisfeuillet Jones", 14.

${ }^{118}$ In 1968, Jones recounted that, "I think the competence of FDA scientifically was underrated. Nevertheless, the scientific community felt that in terms of new drugs, particularly, there was a lack of competence on a broad front properly to evaluate the effects of drugs." U.S. National Library of Medicine, "Interview with Boisfeuillet Jones", 3. 
drugs. ${ }^{119}$ This proposal was then supported by Harvard Medical School's Maxwell Finland. ${ }^{120}$ In 1962, a committee appointed HEW Secretary Celebrezze to assess the FDA also recommended strengthening scientific capacity and improving administrative procedures and practices for handling new drug applications. ${ }^{121}$ The committee argued that the agency needed to augment its scientific capabilities, but faced problems in recruiting and retaining qualified scientific personnel, particularly in the biological and physical sciences. ${ }^{122}$

Finally, and somewhat unsurprisingly, industry also questioned the ability of the FDA to implement the 1962 Amendments. In the summer of 1962, the Pharmaceutical Manufacturers Association (PMA) sponsored a "Commission on Drug Safety" that included experts from industry and academic medicine and was chaired by Lowell Coggenshall (University of Chicago). The commission's aim was to provide suggestions to both the FDA and industry on how to improve their methods and policies. ${ }^{123}$ They also argued that the FDA needed to improve its intellectual capacity. ${ }^{124}$ Austen Smith, the head of the PMA, went on to promote the conclusions of the committee before Congress. Although the industry's criticism of the FDA was

${ }^{119}$ Dowling also recommended increasing salaries, improving facilities and support staff in order to attract higher quality personnel. Dowling saw these advisory panels as a counterweight to the voice of industry in the ears of FDA review staff. U.S. Senate Subcommittee on Antitrust and Monopoly, Administered Prices. Part 24: Administrated Prices in the Drug Industry (Antibiotics), (1960), 86 Cong., $2^{\text {nd }}$ Sess, 14171.

${ }^{120}$ U.S. Senate, Administered Prices (1960), 13932, 13933, 14179.

${ }_{121}^{121}$ Hutt, Reports and Investigations, 540.

${ }^{122}$ U.S. Dept of HEW, Report of the Second Citizen's Advisory Committee, 9, 17.

${ }^{123}$ The commission included Nobel Laureate Philip S. Hench (who had collaborated w/ Merck in the past), Dr. Theodore Klumpp, the former director of the Drug Division of the FDA and current head of the drug firm Winthrop Laboratories and Austen Smith, the former editor of Journal of the America Medical Association and current president of the Pharmaceutical Manufacturers Association. For a full list of members, see: Tobell, Pills, Power and Policy, 131.

${ }^{124}$ The New England Journal of Medicine, "Report of Commission on Drug Safety," 271(1964): 12701271. 
designed to limit the agency's power over drug development, they repeatedly hit on the issue of intellectual capacity that was being raised by other voices as well. ${ }^{125}$

One strategy proposed by critics and supporters alike was to expand the use of committees of external experts in FDA decisionmaking. For example, Senator Humphrey's report on interagency drug coordination recommended that the FDA make better use of expert advisory committees. ${ }^{126}$ The 1962 Citizen's Advisory Committee also recommended that the agency establish advisory committees composed of "eminent scientists and physicians" from professional scientific organizations, universities, and the National Research Council in order "to provide counsel on policies, methods, procedures, personnel development, [and] research." ${ }^{127}$ Furthermore, Senator Humphrey contended "there has been a revolution in drug information" and as a result, "the scientists in the Bureau of Medicine must be encouraged, enabled, and trained to draw upon the fullest competence of the nation's scientific community." "They "must" have available the "cream of the nation's scientific talent for consultation.",128

At the Congressional Hearing on drug safety in 1964, Austen Smith, head of PMA, also stated that: "we believe that scientific advisory panels to the FDA should be established on matters relating to new drugs", because FDA decisions "on scientific questions is becoming increasingly difficult to make as the questions themselves become more and more complex." ${ }^{29}$

${ }^{125}$ U.S. House of Representatives, Subcommittee of the Committee on Government Operations, Drug Safety (Part 1), (1964) 88 Cong., $2^{\text {nd }}$ Sess. 272-302.

${ }^{126}$ Hutt, Reports and Investigations, 541

${ }^{127}$ U.S. Department of Health, Education, and Welfare, Report of the Second Citizen's Advisory Committee, 52.

${ }^{128}$ Cong. Rec. 1962, Vol. 108, Pt. 13:17418.

${ }^{129}$ U.S. House of Representatives, Drug Safety (1964), 278. In 1960, Louis Lasagna, a clinical pharmacologist from Johns Hopkins, stated to Pharmaceutical Manufacturers Association that the only way for FDA to solve workforce and intellectual crisis was for "universities and the pharmaceutical industry (to) join forces in providing reasonable advice to government." Quoted in Tobell, Pills, Power, and Policy, 122-123. 
Given the ties between industry and many academic scientists, they likely felt that they would be able to better influence FDA policy if committees were involved. ${ }^{130}$

\section{Transition to the SyStematic USE OF AdVisory CoMmitTeES}

Following the passage of the Kefauver Harris Amendments, the FDA shifted from incorporating external experts into the policy process mainly through ad hoc consulting arrangements with individuals to assembling experts onto standing advisory committees organized by a topic. The committees formed in the wake of the 1962 amendments were mainly established to help with the transition to a new regulatory regime. By the mid-1960s, the agency began to build an advisory system organized around therapeutic area to aid in the review of new drug applications. I will first provide an overview of the transition to an institutionalized advisory committee system and then discuss in greater depth the emergence of the Committee on Investigational Drugs, the Drug Efficacy Study and Over-the-Counter (OTC) Drug Review, and Advisory Committee on Anesthetic and Respiratory Drugs.

As noted, the Kefauver Harris Amendments expanded the agency's regulatory powers over clinical research. The leadership of the FDA established the Advisory Committee on Investigational Drugs to assist with the implementation and acceptance of the new investigational drug rules. Committee members communicated with other medical researchers about the new regulations, including soliciting information about problems with new rules. ${ }^{131}$ In the transition, the agency also had to evaluate evidence of efficacy for all drugs approved

\footnotetext{
${ }^{130}$ On connections between industry and academic scientists see: John P. Swann, Academic Scientists and the Pharmaceutical Industry: Cooperative Research in the Twentieth Century, (Baltimore, MD: The Johns Hopkins University Press); Marks, The Progress of the Experiment; Tobell, Pills Power and Policy.

${ }^{131}$ This point is also made by Carpenter, Power and Reputation.
} 
between 1938 and 1962. In 1966, the agency contracted with the National Academy of Sciences to assist with the review. These initial prominent committees were used mainly to aid in the transition to a new regulatory regime.

The roots of the contemporary committee system committees lie in the early 1960's. At that point, the agency shifted from using just $a d$ hoc advisers to $a d$ hoc committees and then to standing committees. Commissioner George Larrick established several ad hoc advisory committees for controversial issues of the time. For example, he set up the Advisory Committee on Teratology to advise the agency on the effects of drugs on pregnant women. He also assembled an ad hoc committee to review the new drug application for Enovid, the first oral contraceptive, and another to recommend a course of action on the use of fixed combination antibiotics. ${ }^{132}$ The agency's first standing committee, the Committee on Investigational Drugs, was created in $1963 .^{133}$

Shortly after, Dr. Joseph Sadusk, Jr. assumed the position of director of Bureau of Medicine. He created the Medical Advisory Board and a number of other standing and ad hoc advisory committees. Establishing these advisory committees was the continuation of an agency strategy to "make greater use of non-government experts" and build a system of standing committees throughout the agency. ${ }^{134}$

\footnotetext{
${ }^{132}$ Richard A. Rettig, Laurence E. Earley, and Richard A. Merrill, ed., Food and Drug Administration Advisory Committees, (Washington, D.C.: National Academy Press, 1992), 49; Letter from C. Phillip Miller to Maxwell Finland, September 23, 1960, Finland Papers, Box 2, Folder 24; Letter from Dr. William H. Kessenich Medical Director FDA to Maxwell Finland, June 26, 1962, Finland Papers, Box 2, Folder 24; Letter from Commissioner George P. Larrick to Maxwell Finland, August 13, 1963, Finland Papers, Box 2, Folder 24.

${ }^{133}$ Memo from Frances O. Kelsey to John Swann, “Advisory Committee on Investigational Drugs", November 7, 1994, Frances O. Kelsey Papers, Library of Congress, Washington, D.C., Box 12, Folder 11.

134 "First Meeting of the Medical Advisory Board of the FDA", March 2-3, 1965, Dowling Papers, Box 5, Folder "FDA Structure".
} 
At this time, the FDA began to use the ad hoc committees to aid in the review of individual drug applications. Before a House committee, Director Sadusk argued that this was necessary when the application was controversial or when it was "one in which we do not have the necessary professional talent within the Bureau."135 He further stated that when the agency is internally conflicted he "prefers to then go to the scientific community and receive their assistance in an advisory fashion." ${ }^{136}$ At these early advisory committee meetings, both the FDA leadership and committee members repeatedly discussed the National Institute of Health's (NIH) committee system, which had over 200 committees by 1963, and how that the system improved agency competence giving it "strength". ${ }^{137}$

Upon assuming his position of Commissioner in 1966, Dr. James Goddard temporarily suspended active advisory committees, but upon reviewing their use with the new Director of the Bureau of Medicine, Dr. Herbert Ley, he reinstated their use. ${ }^{138}$ In 1966, he contracted the National Academy of Sciences (NAS) to organize a series of advisory panels to review drugs approved between 1938 and 1962 when the formal regulatory standard did not require manufacturers demonstrate efficacy. In August 1967, he established a system of committees for drugs and supplied each with an administrative staff and a FDA medical officer provided by the Division of Research and Liaison. ${ }^{139}$ Goddard institutionalized a "network of scientific relationships" that would serve as a "publicly established association" between academic

${ }^{135}$ U.S. House of Representatives, Drug Safety (1964), 1369.

${ }^{136}$ U.S. House of Representatives, Drug Safety (1964), 1095.

137 "First Advisory Committee on Investigational Drugs Meeting”, June 17, 1963, John Adriani Papers, U.S. National Library of Medicine, Bethesda, MD, Box 34, Folder 12.

${ }^{138}$ Rettig, Earley, and Merrill, Food and Drug Administration Advisory Committees, 48.

${ }^{139}$ By 1969, the Bureau of Medicine, the division within the FDA overseeing drug review, had 19 committees in place. Rettig, Earley and Merrill, Food and Drug Administration Advisory Committees, 48. 
medicine and the agency. ${ }^{140}$ Even as committees became more institutionalized ad hoc private consultations continued as well. ${ }^{141}$

After the election of Nixon in 1968 and the transition to a new administration, the use of advisory committees was again temporarily suspended. Once Dr. Charles Edwards assumed the position of Commissioner, he ordered that committees resume meeting, and then observed their meetings to assess their worth to the agency. Following these observations, he instructed his staff to allow standing committees to continue their work and expanded their use to other therapeutic areas. ${ }^{142}$ By the early 1970s, the FDA had developed an advisory committee system that sought advice on evaluation and approval of new drugs and medical device products. The agency also solicited advice from committees on new investigational drug applications and the safety and efficacy of already marketed drugs. Commissioner Dr. Charles Edwards explained

\footnotetext{
${ }^{140}$ Carpenter, Reputation and Power, 308, 315.

${ }^{141}$ Examples of Medical Officers reaching out to scientists privately, see: Letter from R.O Knox, to John Adriani, May 4, 1964 Adriani Papers, Box 34, Folder 12; Letter from John Adriani to R.O. Knox May 20, 1964, Adriani Papers, Box 34, Folder 12; Letter from Alvin F. Gardner to John Adriani, July 6, 1964, Adriani Papers, Box 34, Folder 12; Letter from Margaret Clark to John Adriani, December 11, 1968, Adriani Papers, Box 26, Folder 10; Letter from Adriani to Clark, December 16, 1968, Adriani Papers, Box 26, Folder 10; Letter from Clark to Adriani, January 20, 1969, Adriani Papers, Box 26, Folder 10; Letter from Clark to Adriani, March 10, 1969 Adriani Papers, Box 26, Folder 10; Adriani to Clark April 10, 1969, Adriani Papers, Box 26, Folder 10; Clark to Adriani May 5, 1969, Adriani Papers, Box 26, Folder 10; Clark to Adriani June 23, 1969, Adriani Papers, Box 26, Folder 10; Adriani to Clark July 7, 1969, Adriani Papers, Box 26, Folder 10. Exchange between Clark and Adriani was for advice labeling changes and package inserts for penthrane, carbocaine, and mylaxen.

142 The Director of the Bureau of Medicine at the time, J. Richard Crout, supplied this information to Institute of Medicine researchers for Rettig, Earley, and Merrill, Food and Drug Administration Advisory Committees. Committees were resumed in the following areas: antiinfective agents, biometrics, and epidemiological methodology, cardiovascular and renal disorders, dermatology, endocrinology and metabolism, food standards, methadone maintenance, neuropharmacology, obstetrics and gynecology, psychomimetic agents (with the National Institute of Mental Health), radioactive pharmaceuticals and respiratory and analgesic drugs. Rettig, Earley, and Merrill, Food and Drug Administration Advisory Committees, 49.
} 
this expansion as a means to ground the regulatory process in mainstream science, and to generate "protective cover for agency decisions.","143

In 1973, the FDA under Commissioner Alexander Schmidt developed a plan to institutionalize this system further. ${ }^{144}$ He decided to again expand the system of standing committees in "both the developmental process and the subsequent review of data for all important investigational drugs under review in the Agency." $" 145$ When called before Congress by Representative L.H. Fountain (D- NC) to justify this expansion, he argued that the expansion was necessary given the "increasingly sophisticated and complex process" of drug development. ${ }^{146}$ He further explained how "the rotational nature of committee memberships promotes the availability of individuals who are in the forefront of their fields" emphasizing that advisory committees allow the agency to inexpensively supplement expertise with those considered the best current experts. ${ }^{147}$ Schmidt goes on to argue that the agency's "information

\footnotetext{
${ }^{143}$ Quoted in Rettig, Earley, and Merrill, Food and Drug Administration Advisory Committees, 54-55.

${ }^{144}$ U. S. House of Representatives, Subcommittee on Intergovernmental Relations and Human Resources of the Committee on Government Operations, Use of Advisory Committees by the Food and Drug Administration(1974), 93 ${ }^{\text {rd }}$ Congress. $2^{\text {nd }}$ Sess, 27.

${ }^{145}$ U.S. House of Representatives, Use of Advisory Committees by the Food and Drug Administration (1974), 21.

146 Ibid.

${ }^{147}$ U.S. House of Representatives, Use of Advisory Committees by the Food and Drug Administration (1974), 14, 82, 85. In response to Fountain's suggestion that the agency builds expertise internally, Schmidt states: "when one looks at the kinds of expertise that this agency has to have, looks at the cost of these people on the marketplace, looks at the wide number of things that go into whether or not one can hire somebody, looks at the numbers of different kinds of people, it is impossible to structure a self contained totally independent agency. That just simply cannot be done." U.S. House of Representatives, Use of Advisory Committees by the Food and Drug Administration (1974), 85.
} 
needs exceptionally diverse" in way that would be beyond "the total scientific grasp of even an expanded roster of employees." $" 148$

Throughout the congressional hearings on the use of advisory committees in 1974 and 1975, Commissioner Schmidt and the Director of the Bureau of Medicine, Dr. Crout, also argued the way that advisory committees can improve acceptance of agency decisions by improving agency credibility in the scientific community and the broader public. First, Commissioner Schmidt argued that the "[e]xposure of consultants and committee members to the Agency's deliberation and problems promotes a desirable dissemination of information," and that "broadened awareness of Agency approaches and areas of interest promote understanding in the general scientific community." 149 He also argued that an association between a committee of respected outside experts and an agency's policy decision communicates to the public that regulatory policies have "the backing of leaders in the medical, academic, and scientific communities." "150 He further insisted that "to the extent that our pronouncements of any type have stature behind them and have the backing of the scientific community, they have greater impact from a regulatory standpoint". ${ }^{151}$

So, there is evidence that the agency built the system of advisory committees to improve expertise given the breadth and technicality of knowledge required to assess new drug applications. There is also evidence that the agency used connections with respected scientists to improve the public perception of the agency. Although they were unable to hire eminent scientists, they could borrow them through committees and then use the association to build

\footnotetext{
${ }^{148}$ U.S. House, Use of Advisory Committees by the Food and Drug Administration (1974), 1112.

${ }^{149}$ U.S. House, Use of Advisory Committees by the Food and Drug Administration (1974), 14. ${ }^{150}$ U.S. House, Use of Advisory Committees by the Food and Drug Administration (1974), 68.

${ }^{151}$ U.S. House, Use of Advisory Committees by the Food and Drug Administration (1974), 432433.
} 
consensus around agency decisions. The next section examines in greater detail specific advisory committees.

\section{ADVISORY COMMITTEE ON INVESTIGATIONAL DRUGS}

In 1963, the FDA established the Advisory Committee on Investigational Drugs to aid in the interpretation and implementation of investigational drugs provisions of the Kefauver Harris Amendments. The key purpose of this committee was to solicit information about the reaction to the new investigational drug regulations in academic medicine and to build support for the agency from this quarter. ${ }^{152}$ The committee was chaired by Walter Modell of Cornell University and brought together researchers from numerous universities with expertise across a range of clinical areas. ${ }^{153}$ (The committee came to be called the "Modell Committee".) The committee met once a month for about two years until it was dissolved. ${ }^{154}$ After its dissolution, most of its members continued to advise the FDA on other advisory committees.

${ }^{152}$ On rare occasions, they provided technical advice on the specific investigational drug application cases "Summary of Proceedings, Thirteenth Meeting, Advisory Committee on Investigational Drugs," December 3, 1964 Kelsey Papers, Box 12, Folder 1. Discussed specific IND App; LSD-25; after Kelsey presentation; committee found that IND should be terminated ${ }^{153}$ Committee members were: Dr. Walter Modell (Pharmacology, Cornell); John Adriani (Anesthesiology; Charity Hospital New Orleans); Dr. John A.D. Cooper (Dean of Sciences Northwestern); Dr. Sidney Merlis (Pyschiatry, Central Islip Hospital, Long Island); Dr. Harold Hodge, (University of Rochester Medical Center; Pharmacology, Toxicology); Dr. Joseph Volker (University of Alabama Medical Center, Dentistry, Biochemistry); Dr. Charles G. Zubrod (National Cancer Institute). Members were compensated for their time with a per diem of $\$ 70$ for meetings and travel expenses paid. They are not compensated for committee related work done on non-meeting days. "First Advisory Committee on Investigational Drugs Meeting", Minutes, June 17, 1963, Adriani Papers, Box 34, Folder 12; Letter from James L. Goddard to John Adriani, February 14, 1966, Adriani Papers, Box 34, Folder 8.

${ }^{154}$ Letter John Adriani to Dr. Robert T. McSherry, August 16, 1968, Adriani Papers, Box 36, Folder 1); "Summary of Proceedings, Thirteenth Meeting, Advisory Committee on Investigational Drugs," December 3, 1964, Kelsey Papers, Box 12, Folder 1. 
Initially, the committee expressed some confusion as to it's purpose ${ }^{155}$ However, they set to work identifying problems and suggesting solutions on the implementation of the new regulations governing investigational drug research. They spent a significant portion of their meetings discussing the qualified clinical investigator requirement of the new Investigational Drug rules. The requirement aimed at affecting the quality of investigational studies by improving the use of scientific controls, observation of protocols, and recordkeeping. However, regulating who may engage in clinical investigation proved difficult as the agency tried to balance improving the quality of research without unduly deterring investigation into new drug therapies. Committee members were able to gather information from their colleagues about problems with and resistance to the regulations and then provide feedback to the agency and their academic colleagues.

Leaders in the FDA explained to the Congressional Subcommittee on Intergovernmental Relations that the Advisory Committee on Investigational Drugs provided both concrete advice on the new drug approval process and served as a "liaison with the scientific community dealing with investigational drugs. ${ }^{\not 156}$ Dr. Joseph Sadusk, the Medical Director and Director of Bureau of Medicine at the FDA, also argued that the FDA was taking action, particularly with the

155 "Summary- Second Meeting of the Advisory Committee on Investigational Drugs," September 30, 1963, Adriani Papers, Box 34, Folder 12; "Summary of Proceedings Third Meeting Advisory Committee on Investigational Drugs," October 24, 1963, Adriani Papers, Box 34, Folder 12.

${ }^{156}$ U.S. House, Drug Safety (1964), 822. Commissioner Larrick makes a similar point in a letter to committee member John Adriani. He explained that the committee can "keep us informed of problems that arise in the medical and scientific communities", "advise us as to the professionally and ethically sound procedures," and "conveying to their professional colleagues facts concerning the intent of and methods of achieving the improved control of investigational drugs." Letter from George P. Larrick to John Adriani, June 4, 1963, Adriani Papers, Box 34, Folder 13. 
creation of advisory committees, to "promote better understanding, voluntary compliance and support of the investigational drugs programs." ${ }^{157}$

Committee members understood this as their role. At the end of the committee's tenure, Modell explained that "this committee has been of aid to FDA primarily by easing the problems that have developed between the Government and industry and the clinical investigators." Similarly, other committee members describe the committee's work as important in "facilitat[ing] communications" and as a way to "dispel the bitter feeling which existed shortly after passage of the law." ${ }^{, 159}$ In an internal memo, Medical Director Dr. Ralph Smith noted that the committee served as an important conduit of information between the agency and medical researchers throughout the implementation of the new investigational drug rules. ${ }^{160}$

During these committee meetings, members were concerned about the ability of the FDA to competently process of the new drug applications. ${ }^{161}$ In a meeting of the Investigational Drugs Committee, Dr. Sidney Merlis argued "that this was a tremendous task" and "that FDA must 'farm-out' some of this work to outside experts." 162 The agency itself admitted that it needed to improve internal expertise and even solicited advice from committee members on how to recruit more highly qualified personnel and improve the expertise of those already on staff.

157 Ibid.

158 "Summary of Proceedings, Ninth Meeting, Advisory Committee on Investigational Drugs," April 30, 1964, Kelsey Papers, Box 12, Folder 11.

${ }^{159}$ Ibid.; John Adriani to Dr. Robert T. McSherry, August 16, 1968, Adriani Papers, Box 36, Folder 1.

${ }^{160}$ Memo "Advisory Committee on Investigational Drugs: Preliminary Statement on 'Definition of a New Drug;” Dr. Ralph G. Smith, November 18, 1963, Kelsey Papers, Box 12, Folder 11.

${ }^{161}$ This discussion came after Dr. Sadusk presented details of Form 1571 (application process) and explained the process by which each IND application would be evaluated by chemist, toxicologist, and medical officer, before the agency would issue a decision. "Summary of Proceedings, Twelfth Meeting, Advisory Committee on Investigational Drugs," October 29, 1964, Kelsey Papers, Box 12, Folder 11.

162 Ibid. 
Mr. Boifeuillet Jones, Special Assistant to the Secretary for Health and Medical Affairs, plainly stated that it "was obvious that FDA needed medical competence beyond its ability up to that time [1962 when the amendments passed]." ${ }^{, 163}$ He described some of the agency's efforts, including hiring of a New Medical Director (Dr. Joseph Sadusk) from George Washington University, placing Frances Kelsey (an agency public relations star for her role in preventing thalidomide from going to market) in charge of the Investigational Drugs Division, and recruiting more medical personnel. Sadusk also presented a plan for the agency to systematically seek assistance from scientific community through a system of advisory committees. ${ }^{164} \mathrm{He}$ informed the group that a Medical Advisory Board was being set up, and that they were planning to form a series of standing committees to recommend action on specific policy problems.

Both committee members and FDA bureaucrats recognized that there was also a public element to organizational strategies. Jones noted that the agency "needed recognition and an improved image." ${ }^{165}$ Sadusk emphasized the importance of developing a "close liaison with the scientific community." ${ }^{, 166}$ Chairman Modell observed that the agency's regulatory responsibilities will "constantly keep the FDA under fire" and as a result, they "must be defended by outside experts." ${ }^{167}$

The Committee on Investigational Drugs was disbanded two years after it began, but most of the members continued to serve on other committees. These new committees shifted away from broader regulatory issues to assuming a place in the review of specific New Drug

163 "Summary of Proceedings, Ninth Meeting, Advisory Committee on Investigational Drugs," April 30, 1964, Kelsey Papers, Box 12, Folder 11. See also: U.S. National Library of Medicine, "An Interview with Boisfeuillet Jones".

${ }^{164}$ Ibid.

${ }^{165}$ Ibid.

${ }^{166}$ Ibid.

167 "Summary of Proceedings, Twelfth Meeting, Advisory Committee on Investigational Drugs," October 29, 1964, Kelsey Papers, Box 12, Folder 11. 
Applications. The experience of John Adriani and his transition to heading a new committee, the Advisory Committee on Anesthetic and Respiratory Drugs, is illustrative of this transition in the use of advisory committees.

As noted at the time the Modell Committee was being disbanded, Director Sadusk began to set up standing committees organized by therapeutic areas. Dr. John Adriani, a prominent anesthesiologist who also held important positions at the American Medical Association (AMA), was a member of the Modell Committee. From that position, Sadusk recruited him to become the chair of the new Advisory Committee on Anesthetic and Respiratory Drugs. Adriani recalls that one of the committee's FDA liaisons asked him for a list of names of other "prominent and knowledgeable" anesthesiologists throughout the country and then Commissioner Goddard selected a certain number of these. ${ }^{168}$ Each person was appointed annually and had to state that they had no connection with any of the firms whose drug applications the committee reviewed. At this point, neither the composition of the committee nor its meetings were public. However, this will change in 1972 with the passage of the Federal Advisory Committee Act.

The committee met to discuss specific drug applications in their area of expertise. ${ }^{169} \mathrm{Of}$ the committee's role in FDA decisionmaking, he observes that members of the FDA "lean quite heavily on our advice," but that "in many cases our expressions of opinion are merely confirmatory and that the officers in the agency appear to have a good grasp of the problems

\footnotetext{
${ }^{168}$ Letter John Adriani to Dr. Robert T. McSherry, August 16, 1968, Adriani Papers, Box 36, Folder 1.

169 "Minutes First Meeting Respiratory and Anesthetic Drugs Advisory Committee," February 20, 1967, Adriani Papers, Box 36, Folder 1; "Minutes from Second Meeting of Respiratory and Anesthetic Drugs Advisory Committee," June 5, 1967, Adriani Papers, Box 36, Folder 1; "Minutes of Fourth Meeting of Respiratory and Anesthetic Drugs Advisory Committee Meeting," October 24, 1968, Adriani Papers, Box 36, Folder 1.
} 
before them." ${ }^{170}$ However, "it gives them comfort to have the backing of a scientific group."171 In correspondence with another committee member, he notes that with budget cuts leading the review staff to be shorthanded and new bureaucrats "not knowing the ropes" and facing "pressure was put on by the drug houses," the agency reached out to him for more assistance in the review of applications. ${ }^{172}$

\section{DRUg EFFICACY STUdy AND THE OVER-THE-COUNTER DRUg REVIEW}

The Kefauver-Harris amendments required that the FDA review approximately 4,000 drugs that had been approved between 1938 and 1962 under the new efficacy standards. ${ }^{173}$ The agency had to achieve this task with "limitations of staff, budget, and scientific resources." 1966, Commissioner Dr. James Goddard requested that the National Academy of Sciences (NAS) and the National Resource Council (NRC) form advisory panels to assist in this review. The Drug Efficacy Study initially consisted of 30 panels organized by therapeutic area. ${ }^{175}$ The Policy Advisory Panel that organized and directed the other panels. Committee members served without financial remuneration other than a relatively small per diem from October 1967 to

\footnotetext{
${ }^{170}$ Ibid.

${ }^{171}$ Ibid.

172 John Adriani to Dr. Lester C. Mark July 8, 1968, Adriani Papers, Box 36, Folder 2.

173 The law gave manufacturers two years to produce data on effectiveness. Often the data submitted was inadequate, and manufacturers were required to submit additional information. Warren E. Whyte, "Effectiveness of the NAS-NRC Drug Effectiveness Review," Food, Drug, and Cosmetic Law Journal 25 (1970): 92.

${ }^{174}$ Paul A. Bryan and Lawrence H. Stern, “The Drug Efficacy Study, 1962-1970.” FDA Papers, Oct. (1970): 14.

${ }^{175}$ There were initially 27 panels and over time 3 others were added. R. Keith Cannan, "Status of the Drug Efficacy Study of the National Academy of Sciences-National Research Council," Food, Drug, and Cosmetic Law Journal 23(1968): 32-35.
} 
August $1969 .{ }^{176}$ Using the drug sponsor's data, FDA files, and the medical literature, they reviewed 4,349 drug products (consisting of between 300 and 400 chemical entities) and compiled reviews into 2,824 reports. ${ }^{177}$ The committees were responsible for the initial review of the application, and then they would report their assessment of each application to the FDA. ${ }^{178}$ These reports remained confidential. Upon reviewing the reports, the agency made a decision on approval and published the final rule in the Federal Register.

Why use advisory panels in this case? Evidence suggests that the agency had neither the resources nor the range of expertise necessary to review all of these applications. Advisory panels were a way to process the applications in more efficient manner than trying to do so with only in house bureaucrats. In the FDA Papers, the agency argued that the

NAS/NRC was particularly equipped for the task because of the high esteem in which its membership is held throughout the medical and scientific communities and because of its ability to enlist the aid of many of the top scientific and medical experts in the country. ${ }^{179}$

When the NAS-NRC agreed to assist in the drug review, Commissioner Goddard released the following statement to announce the study:

The FDA sought the assistance of the NAS-NRC in carrying out the efficacy study because of that group's unique ability to tap the top medical and other scientific talent of the Nation. ...The FDA itself does not have sufficient medical personnel to carry out a

\footnotetext{
${ }^{176}$ In 1972 , the per diem for the OTC panels was $\$ 128.80$ per day for the meetings. Members were not compensated for the time that they put into prepared for meetings. Letter from Charles C. Edwards to John Adriani, Feb 26, 1973, Adriani Papers, Box 35, Folder 1.

${ }^{177}$ Bryan and Stern, "The Drug Efficacy Study," 14; Cannan, "Status of the Drug Efficacy Study," 33-34.

${ }^{178}$ Whyte, "Effectiveness of the NAS-NRC Drug Effectiveness Review," 97.

${ }^{179}$ Bryan and Stern, "Drug Efficacy Study," 14. Why not use existing advisory committees? In a memo to James Cannan at the NAS-NRC Goddard wrote that existing advisory committees were "are not equipped to undertake a task of this magnitude and cannot be expected to alter their other activities to the extent that would be required." Quoted in Rettig, Early and Merrill, Food and Drug Administration Advisory Committees, 1992, 50.
} 
project of this scope....Recruiting on a temporary basis the skilled scientists required was not considered feasible. ${ }^{180}$

Again, the FDA justified the use of the committees as a way to supplement expertise.

Throughout the implementation process of the Kefauver Harris Amendments, industry criticized the FDA policies. FDA officials used committees to combat such criticism. They saw consulting with respected medical researchers as a way to enhance the credibility of agency decisions. In a memo to Dr. Keith Cannan director of NAS-NRD Division of Medical Science, Commissioner Goddard says:

Recommendations from the most expert sources are essential if this Administration is to suppress flagrant claims, eliminate worthless products and at the same time protect the physician's therapeutic resources. ${ }^{181}$

So, in 1969, when FDA began withdrawing the drugs that failed to meet the efficacy standard from market, the agency could use the NAS/NRC reports to enhance the credibility of their decisions. The response from the pharmaceutical industry ranged from praise to legal action to prevent the removal of drugs deemed ineffective from the market. ${ }^{182}$ Carpenter concludes that this support helped "cement the FDA's position and secure its decisions" from external intervention. $^{183}$

As with prescription drugs, the agency was faced with reviewing all over-the-counter drugs approved between 1938 and 1962 for evidence of efficacy. In 1972, the agency developed an over-the-counter (OTC) review system that was organized around assessing the active

\footnotetext{
${ }^{180}$ Quoted in Rettig, Early and Merrill, Food and Drug Administration Advisory Committees, $1992,51$.

${ }^{181}$ Quoted in Rettig, Earley and Merrill, Food and Drug Administration Advisory Committees, 50 .

${ }^{182}$ The Senior Attorney for Abbott Laboratories, Warren Whyte, called the study a "major scientific accomplishment." Whyte, "Effectiveness of the NAS-NRC Drug Effectiveness Review," 100; Cannan 1968, 33-35; Kenneth Baumgartner, "A Historical Examination of the FDA's Review of Safety and Effectiveness of Over-the-Counter Drugs," Journal of Food, Drug and Cosmetic Law 43 (1988): 466. ${ }^{183}$ Carpenter, Reputation and Power, 315.
} 
ingredients in over-the-counter drugs rather than specific products. ${ }^{184}$ The agency issued regulations detailing four phases of the review. ${ }^{185}$ For the first phase, the FDA set up 17 panels of expert advisers to review all data and studies available on the active ingredients and labeling in 27 categories of OTC drugs. ${ }^{186}$ The OTC review lasted for 10 years and the panels reviewed 1,454 active ingredients in hundreds of thousands of products. ${ }^{187}$

Between the Drug Efficacy Study and OTC review, Congress passed the Federal Advisory Committee Act (1972), which established federal guidelines for the use of committees in agency decisionmaking. These guidelines subjected meeting minutes and reports to the Freedom of Information Act. Whereas in the Drug Efficacy Study, the panel reports were kept private and sent only to the FDA, the OTC panel reports would now be public. These panels also included non-voting industry and consumer representatives, which became standard across FDA committees.

In a letter to an OTC panel member, Commissioner Donald Kennedy stated that:

The industry liaison serves as a resource for the particular industry that will affected by a panel's deliberations and recommendations to ensure that the technical knowledge and interests of the industry are made known to the panel in its evaluation of particular OTC ingredients. The consumer liaison ensures that the interests of consumer protection as

\footnotetext{
${ }^{184}$ Baumgartner, “A Historical Examination of the FDA's Review," 466-68.

185 Baumgartner, "A Historical Examination of the FDA's Review," 468-470.

${ }^{186}$ Baumgartner, "A Historical Examination of the FDA's Review," 473). In reviewing the OTC ingredients, the panels first assess the ingredients. Then they write a short introductory statement and preliminary statement describing group of drugs. Next, they write the individual monograph on the specifications for each drug, including suggested labeling and a policy on combinations. Finally, the FDA lawyers and staff go over it, and "translate it into FDA 'legalese." Letter from John Adriani to Lawrence Cohen, September 12, 1975, Adriani Papers, Box 35, Folder 2.

${ }^{187}$ Rettig, Earley, and Merrill, Advisory Committees in the Food and Drug Administration, 53. The process of review took longer than expected, because panel meetings were open to the public, and there was significant public participation during rulemaking. Also, for many ingredients, there was insufficient scientific evidence. U.S. General Accounting Office, "FDA's Approach to Reviewing Overthe-Counter Drugs is Reasonable, but Progress is Slow," (Washington, D.C.: Government Printing Office, 1982) 7, 35, 36.
} 
they pertain to the particular OTC drugs under review are adequately considered by the panel. ${ }^{188}$

These additions were not without controversy and they caused some friction on the panels. At least some panel members complained about the interference of these industry representatives in the work of the committees. In a letter between two members of the Panel on Topical Analgesics, they expressed concern over potential resistance to a decision from the industry representative on their committee noting that the "little that Chris Costello [industry representative] has furnished thus far is nothing compared to when they turn the big 'eighteen-inch guns' on us." They express concern over the experience of another panel (Oral Analgesics Panel) where the industry representative felt their report was nearly complete when 'they began to receive the 'flak' from the industry it went on and on, and it was almost a year before it was finalized"189

Like the Drug Efficacy Study, the OTC Review was a massive project the agency had to take on in addition to keeping up with the constant flow of new investigational drug applications, new drug applications and supplemental applications. Richard Crout, the Director of the Bureau of Medicine at the time of the OTC review, later explained in an interview that the panels of experts were necessary for two reasons: 1) staff was too small and the lacked "scientific competence" necessary to complete the review and 2) the panels enhanced the credibility of OTC review by having experts bring their "independent judgment" to the cause. ${ }^{190}$ Privately, committee members, like John Adriani of the Panel on Topical Analgesics, argued that the

${ }^{188}$ Letter from Commissioner Donald Kennedy to Thomas G. Kantor, February 17, 1978, Adriani Papers, Box 35, Folder 3.

${ }^{189}$ Letter from John Adriani to Lawrence Cohen, September 12, 1975, Box 35, Folder 2.

190 The Institute of Medicine interviewed Richard Crout for Food and Drug Administration Advisory Committees edited by Rettig, Earley, and Merrill. 
panels "are supplying the scientific expertise which the FDA does not have" and that the contents of panel reports are the "decision are made by the panel and not by the FDA staff."191

\section{CONCLUSiOnS}

The development of advisory committees in the FDA can be seen as part of the agency's struggle to build scientific competence. The agency was delegated responsibility for regulating drugs just as pharmacology and clinical research were undergoing rapid technological change. Although the agency tried to improve capacity by recruiting higher quality personnel to agency, it faced competition for skilled labor especially because a position in the FDA lacked the financial rewards of one in industry and the intellectual freedom of a position in an academic institution. As the FDA came to assume more authority, scrutiny and criticism of it's scientific competence also rose. At this point, the FDA looked to advisory committees to build competence and neutralize public criticism.

Throughout the 1960s, the agency gradually transitioned from soliciting advice from eminent scientists in a private, $a d$ hoc fashion to institutionalizing and regularizing these relationships. The agency did so for two main reasons both related to expertise and the appearance of it. First, they constructed committees in order to lower the costs of information gathering for the permanent staff. Second, the agency was mostly unable to recruit scientists of the highest caliber. Given this and the frequent criticism of the agency's competence, they sought to form associations with these scientists through advisory committees. ${ }^{192}$ Thus, the system of advisory committees developed as a way to supplement in house bureaucratic

${ }^{191}$ John Adriani to Lawrence Cohen, March $2^{\text {nd }}$, 1977; Adriani Papers, Box 35, Folder 2.

192 This is consistent Carpenter's claim the agency formed relationships with scientists outside the agency to improve the agency's reputation. 
expertise thereby improving the FDA's decisionmaking and to enhance the credibility of those decisions. 


\section{WORKS CITED}

Adriani, John. Papers. History of Medicine, U.S. National Library of Medicine. Bethesda, MD.

Balogh, Brian. 1991. Chain Reaction: Expert Debate and Public Participation in American Commercial Nuclear Power, 1945-1975. New York: Cambridge University Press.

Baumgartner, Kenneth. 1988. "A Historical Examination of the FDA's Review of Safety and Effectiveness of Over-the-Counter Drugs." Journal of Food, Drug and Cosmetic Law. 43: 463-494.

Bawn, Kathleen. 1995. "Political Control Versus Expertise: Congressional Choices About Administrative Procedures." American Political Science Review 89: 62-73.

Bryan, Paul A. and Lawrence H. Stern. 1970. “The Drug Efficacy Study, 1962-1970.” FDA Papers. Oct.:14-17

Burke, Sheila ed. 2007. The Future of Drug Safety: Promoting and Protecting the Health of the Public. (Washington, D.C.: The National Academies Press).

Cannan, R. Keith. 1970. "Status of the Drug Efficacy Study of the National Academy of Sciences-National Research Council." Food, Drug, and Cosmetic Law Journal 23(1968): 32-35.

Carpenter, Daniel. 2010. Reputation and Power: Organizational Image and Pharmaceutical Regulation at the FDA. Princeton, N.J.: Princeton University Press.

Carpenter, Daniel and Gisela Sin. 2007. "Policy Tragedy and the Emergence of Regulation: the Food Drug and Cosmetic Act of 1938." Studies in American Political Development. 21(2): 149-180.

Cavers, David F. 1939. "The Food Drug and Cosmetic Act of 1938: Its Legislative History and Substantive Provision." Law and Contemporary Problems 6.1: 2-42.

Congressional Record. 1962. 87th Cong., $2^{\text {nd }}$ sess. Vol. 108, pt. 13.

Daemmrich, Arthur. 2002. "A Tale of Two Experts: Thalidomide and Political Engagement in the United States and West Germany." The Society for the Social History of Medicine. 15(1): 137-158.

Dowling, Harry F. 1957. "Twixt the Cup and the Lip." Journal of the American Medical Association. 165(6): 657-661.

Dowling, Harry F. Papers. The U.S. National Library of Medicine, Bethesda, MD.

Dunn, Charles Wesley, and Vincent A. Kleinfeld. 1949. Federal Food, Drug and Cosmetic Act, 
1939-1949. (New York: Commerce Clearing House).

Finland, Maxwell. Papers. Francis A. Countway Library of Medicine, Harvard Medical Library and Boston Medical Library, Boston, MA.

Friedman, Robert S. 1978. "Representation in Regulatory Decision Making: Scientific, Industrial, and Consumer Inputs to the FDA.” Public Administration Review. 38(3): 205214.

Geiling, Eugene M.K. Papers. The Alan Mason Chesney Medical Archives of The Johns Hopkins Medical Institutions. Baltimore, MD.

Harris, Richard. 1964. The Real Voice. New York: Macmillan Company.

Hilts, Philip J. 2003. Promoting America's Health: The FDA, Business, and One Hundred Years of Regulation. Chapel Hill, N.C.: University of North Carolina Press.

Hutt, Peter Barton. 1983. "Investigations and Reports Respecting FDA Regulation of New Drugs (Part I)." Journal of Clinical Pharmacology and Therapeutics 33(4): 537-548.

Jackson, Charles O. 1970. Food and Drug Legislation in the New Deal. (Princeton, N.J.: Princeton University Press).

Jacobs, Meg. 2005. Pocketbook Politics: Economic Citizenship in the Twentieth Century. (Princeton, N.J.: Princeton University Press).

Jasanoff, Sheila. 1990. The Fifth Branch: Science Advisors as Policy Makers. Cambridge, MA: Harvard University Press.

Kelsey, Frances Oldham. Papers. U.S. Library of Congress. Washington, D.C.

Marks, Harry M. 1997. The Progress of the Experiment: Science and Therapeutic Reform in the United States, 1900-1990. New York: Cambridge University Press.

McCubbins, Mathew, Roger Noll, and Barry Weingast. 1999. "The Political Origins of the Administrative Procedures Act." Journal of Law, Economics and Organization 25(1): 180-217.

Pollack, Andrew. 2013. "F.D.A. Panel Advises Against Two Medicines to Treat Hot Flashes." New York Times, March 4. Accessed on June 16, 2013. http://www.nytimes.com/2013/ 03/05/business/fda-panel-advises-against-two-medicines-to-treat-hot-flashes.html.

Rettig, Richard A., Laurence E. Earley, and Richard A. Merrill, ed. 1992. Food and Drug Administration Advisory Committees Washington, D.C.: National Academy Press.

Scroop, Daniel. 2007. "A Faded Passion? Estes Kefauver and the Senate Subcommittee on 
Antitrust and Monopoly.” Business and Economic History Online. 5: 1-17.

Smith, Bruce L.R. 1992. The Advisers: Scientists in the Policy Process. Washington, D.C.: Brookings Institution Press.

John P. Swann, Academic Scientists and the Pharmaceutical Industry: Cooperative Research in the Twentieth Century, (Baltimore, MD: The Johns Hopkins University Press).

Swann, John. 1997. "Sure Cure: Public Policy on Drug Efficacy Before 1962." In The Inside Story of Medicines: A Symposium, ed. Gregory J. Higby and Elaine C. Stroud (Madison, WI: American Institute of the History of Pharmacy).

Tavernise, Sabrina, and Katie Thomas. 2013. "F.D.A. to Reconsider Restrictions on Diabetes Drug." New York Times, June 2. Accessed June 16, 2013. http://www.nytimes.com/2013/06/03/business/second-thoughts-on-safety-ofavandia-stir-a-dispute.html.

Tavernise, Sabrina, and Katie Thomas. 2013. "F.D.A. Vote is Minor Victory for Troubled Diabetes Drug." New York Times, June 6. Accessed June 16, 2013. http://www.nytimes.com/2013/06/07/business/fda-advisers-vote-to-lift-restrictions-onavandia.html.

The New England Journal of Medicine. [Boston, MA]. 1964. "Report of Commission on Drug Safety.” 271(24): 1270-1271.

Tobbell, Dominique A. 2012. Pills, Power and Policy: The Struggle for Drug Reform in Cold War America and Its Consequences. Berkeley and Los Angeles, CA: The University of California Press.

U.S. Department of Health, Education, and Welfare. Health United States, 1975. DHEW Publication no. (HRA) 76-1232. Washington D.C.: Government Printing Office.

U.S. Department of Health, Education, and Welfare. 1955. Citizen's Advisory Committee on the Good and Drug Administration. Washington, D.C.: Government Printing Office.

U.S. Department of Health, Education, and Welfare. 1976. Annual Reports on the administration of the Federal Food, Drug, and Cosmetic Act and related laws, 1950-1974. Washington, D.C.: Government Printing Office.

U.S. Department of Health, Education, and Welfare. 1962. Report of Second Citizen's Advisory Committee on the Food and Drug Administration to the Secretary of Health, Education, and Welfare. Washington, D.C.: Government Printing Office.

U.S. General Accounting Office. 1982. "FDA's Approach to Reviewing Over-the-Counter Drugs is Reasonable, but Progress is Slow." Washington, D.C.: Government Printing Office. 
U.S. House of Representatives. 1964. Subcommittee of the Committee on Government Operations. Drug Safety (Part 1). 88 Cong., $2^{\text {nd }}$ Sess.

U. S. House of Representatives. 1974. Subcommittee on Intergovernmental Relations and Human Resources of the Committee on Government Operations. Use of Advisory Committees by the Food and Drug Administration. $93^{\text {rd }}$ Congress. $2^{\text {nd }}$ Sess.

U.S. National Library of Medicine. 1968. “An Interview With Boisfeuillet Jones.” General History of Medicine Oral Histories. Accessed at: http://oculus.nlm.nih.gov/cgi/t/text/textidx?c=oralhist;cc=oralhist;rgn=main;view=text;idno=2935135r.

U.S. Senate. 1960. Subcommittee on Antitrust and Monopoly. Administered Prices. Part 24: Administrated Prices in the Drug Industry (Antibiotics). 86 Cong., $2^{\text {nd }}$ Sess.

U.S. Public Law 75-717. $75^{\text {th }}$ Cong., $3^{\text {rd }}$ Sess., 25 June 1938. Federal Food, Drug, and Cosmetic Act.

U.S. Public Law 87-781. 87 $7^{\text {th }}$ Cong., $2^{\text {nd }}$ Sess., 10 Oct. 1962. Drug Amendments of 1962.

Whyte, Warren E. 1970. "Effectiveness of the NAS-NRC Drug Effectiveness Review." Food, Drug, and Cosmetic Law Journal 25: 91-100.

Young, James Harvey. 1992. The Medical Messiahs: A Social History of Health Quackery in the Twentieth-Century America. (Princeton, N.J.: Princeton University Press). 


\section{CONCLUSION}

If agencies are going to competently confront some of the most pressing policy issues of our day, building and maintaining bureaucratic capacity is critical. Issues, such as climate change, natural resource extraction, financial crises, and the threat of bioterrorism or a global pandemic, are tremendously complex and designing policymaking in these areas requires highly specialized expertise. The extent to which agencies are able to recruit and retain highly skilled personnel and the extent to which they are able to compel these individuals to update their knowledge and skills over time is unknown. At present, there is only limited research on how governments cope with these demands for expertise, and how political actors could structure bureaucratic decisionmaking to improve agency capacity. ${ }^{193}$

The goal of this dissertation was to provide some insight into how agencies cope with policy uncertainty and the strategies they adopt to improve agency capacity. Together, these three papers provide evidence that agencies in highly technical policy areas have tremendous informational demands put upon them, and agencies respond by adopting strategies to acquire expertise. Both recruiting highly skilled bureaucrats and then compelling them to update their expertise with technological change is difficult. However, agencies can use administrative procedure, like advisory committees, to manipulate the costs and benefits associated with information gathering. Agencies create advisory committee when policy uncertainty is high. Once created, committees affect policy outcomes. However, these findings also raise several important questions.

${ }^{193}$ For some recent work on agency capacity, see: Lewis and Gallo 2012, Lewis 2010, and Ting 2011. 
First, research on delegation has emphasized the ways that Congress can control bureaucratic outcomes through the structure and process of agency decisionmaking (McCubbins, Noll and Weingast 1987, 1989). Congress can shape the content and flow of information available to agencies to bias outcomes towards their preferences (Balla and Wright 2001). However, I demonstrate that Congress does not have a monopoly on shaping the agency's information sources, and that agency secretaries as well as Congress can shape the information sources used in rulemaking. There is little evidence that agencies establish committees when ideological divergence is present. However, through mandating consultation with advisory committees, agency secretaries affect the type of information sources bureaucrats draw from. So in this way, they could guide decisions by bringing bureaucrats in regular contact with external experts they trust. For example, the head of FDA may appoint a committee of highly, skilled qualified experts who can reduce policy uncertainty in order to avoid mistakenly approving drugs that pose great risk or are ineffective. However, the Commissioner could staff the committee with experts who share their preferences over how risk averse the agency should be to bias bureaucrats' decisionmaking. The extent to which agency leaders are doing so is still unknown.

In addition, I demonstrate that agencies create committees as a strategy to improve competence and that their input likely affects policy decisions in the FDA, but have not yet investigated how they affect the quality of outcomes. We do not know whether bureaucrats have better information and less policy uncertainty than they would without the input of advisory committees. For example, do advisory committees actually reduce the probability that harmful drugs are approved or do they simply allow the bureaucrat to shirk? 
Finally, the first paper finds that liberal technical agencies are more likely to establish advisory committees than conservative technical agencies. If these conservative technical agencies, like the Nuclear Regulatory Commission, the Commodity and Futures Trading Commission, and the Department of Commerce, are not turning to advisory committees, what strategies are they adopting to acquire expertise? How do the challenges of acquiring expertise in these policy areas differ from those of liberal technical agencies, like the FDA or the EPA? Are they better able to recruit qualified personnel, less competition for skilled labor? Do private sectors actors willingly provide information and expertise they need? Do they further delegate to private contractors? Future research on the bureaucratic expertise will need to contend with how the challenge of acquiring expertise will vary across technical policy areas and the effect of these differences on agency capacity. At present, there are many open questions that need to be answered before we can claim a comprehensive understanding of the politics of expertise in contemporary bureaucratic policymaking. 


\section{WORKS CITED}

Balla, Steven J. and John Wright. 2001. "Interest Groups, Advisory Committees, and Congressional Control of the Bureaucracy." American Journal of Political Science 45: 799-812.

Gallo, Nick and David E. Lewis. 2012. " The Consequences of Presidential Patronage for Federal Agency Performance." The Journal of Public Administration Research and Theory 22: 219-243.

Lewis, David E. 2010. The Politics of Political Appointments. Princeton, N.J.: Princeton University Press.

McCubbins, Mathew D., Roger G. Noll, and Barry R. Weingast. 1987. "Administrative Procedures as Instruments of Control." Journal of Law, Economics and Organization 6: 267-298.

McCubbins, Mathew D., Roger G. Noll, and Barry R. Weingast. 1989. "Structure and Process, Policy and Politics: Administrative Arrangements and the Political Control of Agencies." Virginia Law Review 75: 431-482.

Ting, Michael M. 2011. "Organizational Capacity.” Journal of Law, Economics, and Organization. 27(2): 245-271. 